\title{
DIGITALCOMMONS
}

$1-1-2002$

\section{Antitrust, Health Care Quality, and the Courts}

Peter J.Hammer

Wayne State University, peter.hammer@wayne.edu

William M. Sage

Columbia University

\section{Recommended Citation}

Peter J. Hammer \& William M. Sage, Antitrust, Health Care Quality, and the Courts, 102 Colum. L. Rev. 545 (2002). Available at: http://digitalcommons.wayne.edu/lawfrp/40

This Article is brought to you for free and open access by the Law School at DigitalCommons@WayneState. It has been accepted for inclusion in Law Faculty Research Publications by an authorized administrator of DigitalCommons@WayneState. 


\title{
ARTICLES
}

\section{ANTITRUST, HEALTH CARE QUALITY, AND THE COURTS}

\author{
Peter J. Hammer* E William M. Sage**
}

\begin{abstract}
Antitrust law represents the principal legal tool that the United States employs to police private markets, yet it often relegates quality and nonprice considerations to a secondary position. While antitrust law espouses the belief that vigorous competition will enhance quality as well as price, little evidence exists of the practical ability of courts to deliver on that promise. In this Article, Professors Hammer and Sage examine American health care as a vehicle for advancing understanding of the nexus among competition, quality, and antitrust law. The Article reports the results of a comprehensive empirical review of judicial opinions in health care antitrust litigation between 1985 and 1999, with specific attention to courts' handling of quality and other nonprice concerns. Professors Hammer and Sage conclude that, although antitrust law cannot be expected to serve as the sole oversight mechanism for industries as complex and quality dependent as health care, courts have been successful incorporating some nonprice factors into antitrust analysis.
\end{abstract}

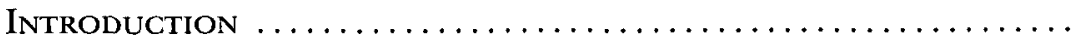

I. Research Methods ......................... 550

A. Selecting and Coding Judicial Opinions .......... 553

I. Developing the Coding Instrument .......... 553

2. Case Selection ....................... 553

3. Coding ............................ 554

B. Coding Quality of Care $\ldots \ldots \ldots \ldots \ldots \ldots \ldots \ldots \ldots .555$

C. Limitations of the Methodology ................ 559

II. Empirical Results ......................... 564

A. Private Medical Antitrust Litigation ............. 565

I. Parties ............................. 566

2. Business Conduct ...................... 567

3. Geography $\ldots \ldots \ldots \ldots \ldots \ldots \ldots \ldots \ldots \ldots \ldots \ldots \ldots \ldots, 57 \mathrm{I}$

* Assistant Professor of Law, University of Michigan. B.A., B.S., Gonzaga University, 1986; J.D., University of Michigan, 1990; Ph.D. (economics), University of Michigan, 1993. ** Professor of Law, Columbia University. A.B., Harvard College, 1982; M.D., J.D., Stanford University, 1988. The research reported in this Article was supported by an Investigator Award in Health Policy Research from the Robert Wood Johnson Foundation. Professor Jeffrey Fagan of Columbia University served as our statistical consultant. We extend special thanks to Aaron Hovan and Magda Schaler for supervisory research assistance, to Miryam Frieder for data management, and to Ted Afield, Pamela Alford, Cary Allen, Megan Brodkey, Morisa Forman, Carole Friedman, Yingtao Ho, Eric Hong, Ellen Lin, Julia Miller, Pamela Nolan, and Nina Russakoff for coding judicial opinions. We also gratefully acknowledge comments from Tim Greaney, Clark Havighurst, David Hyman, Tom Kauper, and participants in conferences and workshops held at Boston University, Case Western, Columbia, Duke, and Northwestern. 
4. Court............................ 574

5. Procedural Posture and Outcome ............ 574

6. Antitrust Allegations and Violations .......... 578

7. Antitrust Analysis........................ 581

B. Public Antitrust Enforcement ............... 585

C. Judicial Assessment of Quality ................ 588

III. Discussion of Legal and Policy Implications .......... 593

A. 1s Medical Antitrust Litigation Socially Useful?....... 594

1. Private Litigation...................... 595

2. Public Enforcement.................... 604

B. How Do Antitrust Courts Approach Quality and

Nonprice Competition? .................... 609

1. The Unquestioned Orthodoxy: The Virtues of Competition ....................... 611

2. Challenging the Orthodoxy: Hospital Mergers.... 614

3. Quality as "a Part of" or "Apart from" Competition ........................ 617

4. Quality as a Component of Individual Firms or as an Attribute of Systems................... 620

5. Quality as an Abstract Notion or as a Specific Characteristic .............................

6. Choice and Information as Dimensions of Quality .............................. 623

7. Innovation and Quality.................. 626

8. Managed Care, Antitrust, and Quality ......... 631

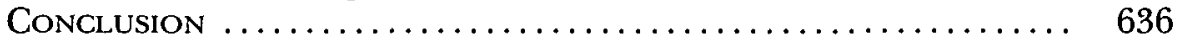

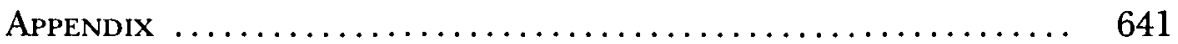

\section{INTRODUCTION}

It is getting harder to compete. Certainly, intensity of competition has increased with globalization of markets. But the terms of competition have also become more complex. No longer do competitors think only about keeping physical output high and prices low. In addition, producers, consumers, and those who monitor them must pay attention to scope, service, quality, innovation, and various synergies that may result from product or market interconnections. These considerations influence most markets and dominate a few, such as information technology, telecommunications, transportation, energy, and various professional and technical services.

Not coincidentally, many of these important, complex, and evolving industries are regulated or recently deregulated. Like the proverbial balloon, competition in regulated products responds to the push or pull of regulatory constraints by channeling energy into, or diverting attention away from, the areas being left alone. Price caps, for example, erode competition on nonprice features of products, while price supports en- 
hance nonprice competition. ${ }^{1}$ When regulation changes in nature or extent, moreover, the intricacies of the competitive response may be dizzying.

In this environment, what are antitrust enforcers and antitrust theorists to do? Antitrust law represents the principal legal tool the U.S. employs to police private markets. Unfortunately, as the Microsoft litigation amply demonstrates, antitrust law is not particularly well equipped to address in real time the nonprice dimensions of twenty-first century commerce. $^{2}$ In general, modern antitrust law emphasizes basic microeconomic analysis of the effect of competition on price and output, with occasional "post-Chicago School" refinements. ${ }^{3}$ Consequently, antitrust law often relegates quality and nonprice considerations to a secondary position. ${ }^{4}$ While antitrust law espouses the belief that vigorous competition will enhance quality as well as price, and therefore purports to safeguard a wide range of nonprice concerns through its oversight of price competition, there exists little proof of either the conceptual basis for such an enterprise or the practical ability of courts to deliver on that promise.

1. For the first point, at least those of a certain age can think gasoline. Souvenir glasses, promotional contests, and even check-your-oil "service with a smile" were quick casualties of price controls in the 1970s. For the second point, think air travel under FAA regulation. Frequent, uncrowded flights, better food, and other amenities were easy for airlines to provide at high regulated fares. See, e.g., Stuart M. Butler, The Fatal Attraction of Price Controls, in Health Policy Reform: Competition and Controls 3, 13-14 (Robert B. Helms ed., 1993) (discussing the negative effect of price controls on quality of services). For a formal economic discussion of the symmetries between price competition under conditions of fixed quality and quality competition under conditions of fixed prices, see George J. Stigler, Price and Non-price Competition, 76 J. Pol. Econ. 149, 149-52 (1968).

2. United States v. Microsoft Corp., 253 F.3d 34 (D.C. Cir. 2001); see Dennis M. Kennedy, Key Legal Concerns in E-Commerce: The Law Comes to the New Frontier, 18 T.M. Cooley L. Rev. 17, 34 (2001) ("Today's court case often seems to be about last year's technology. By the time a case has run its course . . . the technology may already be obsolete or the business environment may have changed drastically."); see also Kenneth G. Elzinga et al., United States \%. Microsoft: Remedy or Malady?, 9 Geo. Mason L. Rev. 633, 634 (2001) (criticizing Microsoft litigation); David S. Evans et al., An Analysis of the Government's Economic Case in U.S. ». Microsoft, 46 Antitust Bull. 163, 166-70 (2001) (same).

3. Herbert Hovenkamp, Federal Antitrust Policy: The Law of Competition and its Practice \$\$ 2.2-2.3 (2d ed. 1999) (discussing role and domain of Chicago School economics in contemporary antitrust law). Populist concern over the fate of small business has receded in today's predominantly economic antitrust doctrine. Similarly, the historic emphasis on evil intent as a precondition to antitrust liability has faded in favor of a pure effects test. ld.

4. For discussions about how contemporary economic approaches to antitrust law often neglect quality and nonprice competition (even as economically understood), see Neil W. Averitt \& Robert H. Lande, Consumer Sovereignty: A Unified Theory of Antitrust and Consumer Protection Law, 65 Antitrust L.J. 713, 750-51 (1997); Douglas H. Ginsburg, Nonprice Competition, 38 Antitrust Bull. 83, 83 (1993); E. Thomas Sullivan, On Nonprice Competition: An Economic and Marketing Analysis, 45 U. Pitt. L. Rev. 771, 776 (1984). 
In this Article, we examine American health care as a vehicle for advancing scholarly understanding of the nexus among competition, quality, and antitrust law. Using a detailed case coding instrument in addition to the textual analysis that is standard fare for law professors, we conducted a comprehensive examination of health care antitrust enforcement between 1985 and 1999, comprising over 500 judicial opinions and nearly 100 consent decrees and formal administrative actions. Our results demonstrate that antitrust litigation is commonly employed by private parties (and to a lesser extent by government) to influence the development of medical markets. However, we find that-even in recent years when competition has been fierce-surprisingly few suits present persuasive claims of competitive harm, whether price or quality related. Furthermore, while courts deal assertively with health antitrust cases and employ standard economic tools in their analyses, they seldom address quality as a specific competitive dimension, rather than as a regulatory matter. Interestingly, this institutional limitation does not extend to the competitive analysis of market choice, which antitrust law approaches with confidence.

These insights help fill empirical gaps in both the antitrust and the health policy literatures. Professional activities in general, and health care in particular, are relative newcomers to antitrust scrutiny. Although conflicts among physicians or between physicians and other health professionals generated antitrust enforcement activity as early as 1943 in American Medical Ass' $n v$. United States, ${ }^{5}$ medical pricing policies and other restrictions involving customers rather than rival suppliers did not come clearly within the ambit of antitrust law until the mid 1970s and early 1980 s in cases like Goldfarb v. Virginia State Bar, ${ }^{6}$ National Society of Professional Engineers v. United States, ${ }^{7}$ and Arizona v. Maricopa County Medical Society. ${ }^{8}$ Moreover, few professional economists paid serious attention to medical markets before the $1960 \mathrm{~s},{ }^{9}$ and even today's widespread invoca-

5. 317 U.S. 519, 528-29 (1943).

6. 421 U.S. 773, 792-93 (1975) (holding minimum fee schedule for lawyers illegal under Sherman Act while observing that the profession may merit special treatment).

7. 435 U.S. 679,696 (1978) (holding illegal professional ban on competitive bidding, but allowing tbat "professional services may differ significantly from other business services").

8. 457 U.S. 332, 335-37, 357 (1982) (finding price fixing agreement between "competing pbysicians setting, by majority vote, the maximum fees that they may claim in full payment for health services provided to policyholders of specified insurance plans" per se illegal under Sherman Act).

9. The best known early effort is Kenneth J. Arrow, Uncertainty and the Welfare Economics of Medical Care, $53 \mathrm{Am}$. Econ. Rev. 941 (1963) (contending that uncertainties inherent to medical care-relating especially to the incidence of disease and the efficacy of treatment-generate special economic problems that contradict the usual assumptions of the market). For a comprehensive contemporary analysis of Arrow's article and its influence, see Special Issue: Kennetb Arrow and the Changing Economics of Health Care, 26 J. Health Pol., Pol'y \& L. 823, 823-1214 (2001) (collecting essays). 
tion of economics to explain behavior in health care continues to provoke an extensive literature critical of market analysis. ${ }^{10}$

With the rise of managed care, competition has now firmly taken root in health care markets once dominated both economically and substantively by professional values and is reshaping the manner in which medicine is practiced and purchased in America. Antitrust law can take some credit for this transformation, but it should also bear commensurate responsibility. Most importantly, health care quality is by many accounts threatened by vigorous price competition involving physicians, hospitals, health insurers, and other medical suppliers. ${ }^{11}$ At the same time, the health care regulatory process shows limited ability to address quality concerns without significantly restricting the benefits of competition.

Our study is intended to determine whether antitrust law currently possesses the tools to take risks to quality into account and to respond appropriately. The answer to this question can shed light not only on the preferred model for governing health care markets but on the relationship between competition and regulation generally and the institutional capacity of private litigation to serve what are in essence regulatory objectives. $^{12}$ A precondition to making sound policy recommendations in

10. See, e.g., Thomas Rice, Can Markets Give Us the Health System We Want?, $22 \mathrm{~J}$. Health Pol., Pol'y \& L. 383, 383-85 (1997) (questioning ability of market forces to channel health policy in socially appropriate directions).

11. See Jane E. Sisk, Increased Competition and the Quality of Health Care, 76 Milbank Q. 687, 688 (1998) ("As price competition is growing, the challenge is to create conditions that safeguard the quality of care and reward its improvement over time in a manner that is consistent with the public's preferences."). Whether markets and competition will be able to deliver on both price and quality dimensions remains to be seen. One reason for skepticism is the basic incentive structure underlying systems of prepayment. See Marcia Angell \& Jerome P. Kassirer, Quality and the Medical Market Place-Following Elephants, 335 New Eng. J. Med. 883, 883 (1996). Angell and Kassirer observe:

[Q]uality of health care is now seriously threatened by our rapid shift to managed care as the way to contain costs. Managed-care plans involve an inherent conflict of interest. On the one hand they pledge to take care of their enrollees, but on the other their financial success depends on doing as little for them as possible.

1d. Moreover, consumers may not be in a position where they can accurately detect "stinting." Joseph P. Newhouse et al., Risk Adjustment and Medicare: Taking a Closer Look, Health Aff., Sept./Oct. 1997, at 26, 27 (defining "stinting" as the underprovision of services by prepaid plans). Another reason for skepticism is that no simple price-quality metric exists that permits problems of quality to be reduced to more easily resolved problems of price competition. Elizabeth A. McGlynn, Six Challenges in Measuring the Quality of Health Care, Health Aff., May/June 1997, at 7, 8 ("If there were a precise relationship between price and quality, we would only need to know how to translate premium prices and other charges into quality units. However, because there is no such direct relationship, a separate set of quality measures is essential." (footnote omitted)).

12. Our work therefore relates indirectly to a growing body of literature evaluating control of tobacco, guns, and other commercial activities with health or safety implications through the courts rather than legislatures and administrative bodies. See The RegulationLitigation Interaction (W. Kip Viscusi, ed.) (forthcoming 2002). 
these areas is a clear baseline understanding of the demands being made on antitrust law and the institutional competency of courts and enforcement agencies. In this Article we undertake and present such an empirical assessment. We intentionally cabin the scope of policy analysis in this Article to organizing our empirical findings, and reserve a full theoretical treatment of the issues to separate work, where we outline the contours of an integrated competition policy in health care. ${ }^{13}$

\section{Research Methods}

The health care industry has been the subject of substantial antitrust enforcement and legal scholarship, but to our knowledge our study represents the first systematic attempt to evaluate the role of quality and other nonprice concerns in health care antitrust litigation, or to assess the capacity of judges to undertake such forms of analysis. Because our goals and methods differ slightly from those traditionally associated with legal scholarship, we present our findings using conventions from scientific research, although we gratefully acknowledge the liberal space allowance that law review publication affords us. We take this approach in order that readers may evaluate the methods we employed and assess for themselves the persuasiveness of our findings. Accordingly, this section describes the manner in which we identified relevant antitrust disputes and analyzed their content, and it discusses the limitations of our methodology as well as its advantages. We also attach the coding instrument used to categorize judicial decisions as an Appendix to the Article. Readers who are interested primarily in our findings and how we interpret them should feel free to turn directly to our presentation of empirical results in Part II.

Despite the long history of the Sherman Act, there have been relatively few efforts to analyze empirically the nature of public and private antitrust enforcement. Among previous studies, the most common methodology has been to report on a random sample of antitrust cases filed in selected federal district courts and to gather data from court dockets, with occasional follow-up surveys of the attorneys litigating those cases to

13. A conceptual analysis of our empirical results can be found in William M. Sage \& Peter J. Hammer, A Copernican View of Health Care Antitrust, 65 Law \& Contemp. Probs. (forthcoming 2002). This Article is part of a larger study, titled Competing on Quality of Care: Comparing Antitrust Law to Market Reality, which is supported by an Investigator Award in Health Policy Research from the Robert Wood Johnson Foundation. This project also will examine in greater detail the work of the federal antitrust enforcement agencies in encouraging quality competition in medical markets and will explore how antitrust enforcement can be reconciled with other government regulatory and purchasing objectives as part of a broader "competition policy" for the health care sector. We have outlined the intellectual framework of the project elsewhere. See William M. Sage \& Peter J. Hammer, Competing on Quality of Care: The Need to Develop a Competition Policy for Health Care Markets, 32 U. Mich. J.L. Reform 1069 (1999) [hereinafter Sage \& Hammer, Competition Policy]. 
gain additional information about settlement practices. ${ }^{14}$ The Georgetown Antitrust Project, ${ }^{15}$ a NERA study commissioned by the American Bar Association, ${ }^{16}$ a GAO report of Department of Justice (DOJ) antitrust enforcement practices, ${ }^{17}$ and an early study by Richard

14. This was the method employed in the Georgetown Antitrust Project, infra note 15, and the NERA study, infra note 16. Only the Georgetown Antitrust Project sent follow-up surveys to the attorneys.

15. See Private Antitrust Litigation: New Evidence, New Learning (Lawrence J. White ed., 1988) [hereinafter Private Antitrust Litigation]. The Georgetown Antitrust Project provides the most extensive examination to date of private antitrust litigation. The study collected data on private antitrust cases filed in five federal districts (Manhattan, Chicago, San Francisco, Kansas City, and Atlanta) between 1973 and 1983. The sample produced 2357 cases (approximately one-sixth of all private cases filed during the time period). See Steven C. Salop \& Lawrence J. White, Private Antitrust Litigation: An Introduction and Framework, in Private Antitrust Litigation, supra, at 3-16 (providing an overview of the data). Data were obtained from the docket files and surveys were sent to the attorneys to inquire about settlements and fees. The study reports, among other things, distribution of cases by economic sector, antitrust statute sued under, illegal practices complained of, and business relationships between the parties. The study does not examine published opinions, nor does it evaluate the legal reasoning of particular courts. The data, however, permit fairly extensive investigation of the settlement dynamics of private antitrust litigation and have spawned substantial scholarship into the nature and social utility of private antitrust enforcement. See generally Private Antitrust Litigation, supra (collecting articles by antitrust scholars such as Stephen Calkins, Kenneth G. Elzinga, Thomas E. Kauper, Daniel L. Rubinfeld, Edward A. Snyder, and Donald F. Turner exploring the implications of the data generated by the Georgetown Antitrust Project).

16. Nat'l Econ. Research Assocs., lnc., A Statistical Analysis of Private Antitrust Litigation: Final Report for the American Bar Association Section of Antitrust Law (1979) [hereinafter NERA, Antitrust Report]. NERA collected data on private antitrust cases filed in the Southern District of New York between 1973 and 1978. Id. at 7-15 (summarizing the study methodology). A random sample of cases was selected, representing 55-63\% of all cases each year, for a total sample size of 352 cases. Data were obtained from the docket files and include information concerning the identities of the parties, the nature of the dispute (alleged unlawful conduct, statutory violations, and affected products and markets), procedural aspects of the litigation (class certification, counterclaims, nature and length of discovery), the resolution (pending status, dismissal, settlements, judgments, and whether an appeal was taken), and the extent, if any, of public antitrust involvement. Id. at 17-18. Unlike the Georgetown Antitrust Project, no follow-up surveys were sent to attorneys, providing less information on settlement practices. The study does not examine published opinions, nor does it attempt to assess the legal reasoning in particular decisions. For a discussion of the NERA study, see James P. Melican, Jr., The Treble Damage Case: Fact and Fiction, 49 Antitrust L.J. 981, 984-86 (1980).

17. Gen. Accounting Office, Justice Department: Changes in Antitrust Enforcement Policies and Activities (1990) [hereinafter GAO Report]. 1n 1990, the General Accounting Office published a report on the antitrust enforcement practices of the Department of Justice. The GAO examined DOJ resources and enforcement agency activity over a twenty year period between 1970 and 1989 to determine whether there had been systematic changes in antitrust enforcement strategies in the 1980s. Id. at 2-3. The GAO also reviewed summaries of all merger cases challenged by the Department between 1982 and 1987. The merger summaries were prepared by DOJ personnel. Id. at 52. The GAO found that in the 1980s, the DOJ's policy shifted from civil to criminal enforcement (primarily bid rigging and price fixing cases). Id. at 53. Between 1980 and 1989, the DOJ filed an average of 81 criminal cases and 13 civil cases annually (compared with an average of 20 criminal cases and 48 civil cases annually between 1970 and 1976). Id. at 39-47. 
Posner ${ }^{18}$ are the most important previous empirical contributions. The Georgetown and NERA approaches provide information about not only the cases that go to trial, but also the cases that settle or are dismissed. To the extent that these studies document discovery practices and other events occurring between the filing of a complaint and trial, they also improve our understanding of strategic behavior during the course of litigation. Unfortunately, none of these studies focuses on the health care industry, even as a specific subset of the cases evaluated. Neither do these studies examine the role of quality and nonprice concerns, or systematically analyze judicial reasoning in the opinions produced by litigation. ${ }^{19}$

We elected to assess the underlying capacity of antitrust courts to address quality concerns by examining judicial opinions in federal courts. We reviewed all opinions that were available on LEXIS, including opinions not formally "published" in official reporters. For cases brought by public antitrust enforcement authorities, we supplemented judicial opinions with settlements and administrative decisions. Admittedly, these materials capture only part of the universe of health care antitrust litigation. Many cases are dropped or settled without a court's formal involvement, ${ }^{20}$ while others run their full course through trial and still do not

Unfortunately, health care is not isolated in the analysis, nor are the activities of the Professions and Intellectual Property Section of the Antitrust Division or its policies towards hospital inergers subject to any specific examination.

18. Richard A. Posner, A Statistical Study of Antitrust Enforcement, 13 J.L. \& Econ. 365 (1970). Posner examined historical trends in public and private antitrust enforcement from 1890 to 1969. Posner reports data on the number of filings, the nature of alleged antitrust violations, length and outcome of proceedings, and choice of remedies. Most of the information is collected from public sources, such as the CCH Trade Regulation Reporter, as well as case summaries provided by the federal enforcement agencies. While Posner's primary focus is on patterns of public enforcement, useful trend data are also reported on private litigation: comparisons of criminal/civil enforcement ratios, ratios of private/public suits over time, and outcomes (win-loss ratios). Id. passim. Again, there is no sector specific analysis and no systematic effort to examine how courts address particular issues such as nonprice competition.

Posner's work was later extended by William Baxter. See William F. Baxter, The Political Economy of Antitrust, in The Political Economy of Antitrust 3, 16-26 (Robert D. Tollinson ed., 1980) (discussing Posner's findings on the mix of public and private Iitigation and upon the extremely low success rates among private antitrust plaintiffs). For further analysis of private litigation prior to 1964 , see John D. Guilfoil, Private Enforcement of U.S. Antitrust Law, 10 Antitrust Bull. 747 (1965) (noting divergence of judicial opinion and excessive duration of proceedings).

19. But cf. Pauline M. Ippolito, Federal Trade Comm'n, Resale Price Maintenance: Economic Evidence From Litigation (1988) (performing systematic examination of all 203 public and private litigated cases between 1976-1982 containing allegations of vertical price fixing to assess competing theories of resale price maintenance). The Ippolito report also discusses a number of the methodological issues a researcher faces in relying upon a set of litigated court cases as a database from which to make empirical and theoretical assessments about the underlying economic conduct. Id. at 25-35.

20. The Georgetown Antitrust Project estimated that some $73 \%$ of all filed private antitrust cases settle or are dismissed before resulting in a judgment. Salop \& White, supra 
result in an opinion. Nonetheless, judicial opinions are the appropriate unit of analysis for the questions of principal interest to us: "how" and "how well" antitrust courts have evaluated the quality concerns that are brought before them. Because antitrust litigation is fact intensive, with limited controlling precedent, we cannot answer these questions using traditional legal research methods that try to ascertain "what the law is." Instead, we use the written opinion as a window into the courtroom to determine what role quality concerns have played in antitrust litigation, what types of quality related arguments have been made and in which settings, how courts define and understand quality in health care (if at all), and what assumptions antitrust courts make about the effect on quality of competition or specific alleged restraints of trade.

\section{A. Selecting and Coding Judicial Opinions}

1. Developing the Coding Instrument. - Given the task of examining several hundred medical antitrust opinions, a major challenge was to devise a uniform, systematic means of classifying information. We therefore developed a comprehensive survey instrument to be used to "code" each opinion, a copy of which is reproduced in the Appendix. The coding instrument records several descriptive characteristics of the parties, the procedural posture of the case, case outcomes, the substantive antitrust allegations discussed by the court, the methods of antitrust analysis performed by the court, and a lengthy set of quality and nonprice concerns. $^{21}$ Some of these attributes are straightforward and relatively easy to identify. For example, the instrument requests information about the plaintiff's and defendant's identities (physician, hospital, insurance company, etc.), their location, and the type of business conduct in question in the case (for example, merger, exclusive contracting, private credentialing). These subjects can be coded with a fairly high degree of reliability. By contrast, matters such as "significant" case outcomes and the forms of antitrust analysis performed by courts require a greater degree of interpretive judgment on the part of the coder and were therefore subjected to more intensive review.

2. Case Selection. - After developing the coding instrument, we set out to locate relevant cases. Using LEXIS, we searched electronically for health care antitrust cases decided between 1985 and $1999 .{ }^{22}$ Health care

note 15 , at 10 . The 1979 NERA study placed the private antitrust settlement rate at $84 \%$. NERA, Antitrust Report, supra note 16, at 44. By coding all published opinions, and not simply cases that result in a final judgment, we capture cases dismissed by courts in published opinions and those that may in fact settle without a trial after the motion being addressed in the opinion is decided. As such, the settled/not settled distinction used elsewhere does not map well onto our cases.

21. The list of quality concerns is discussed in detail infra Part 1.B.

22. We selected this fifteen-year period because it encompassed enough of the recent history of health care to include reliably a variety of competitive situations but not so much that the number of cases generated would be unmanageable. 
was broadly defined to include disputes involving pharmaceuticals, medical devices, and other medical products in addition to a range of professional, institutional, and financial services. ${ }^{23}$ Dentistry, chiropractic and the like were included; dietary and veterinary cases were not. Our original search identified 3390 cases. ${ }^{24}$ A law student research assistant screened these cases, discarding ones where the underlying dispute clearly had nothing to do either with antitrust law or with health care. Cases of doubtful but possible relevance were retained. Screening reduced the number of cases to 988 , which were scheduled for full coding. Using the same search terms in other LEXIS library files, we also assembled a supplemental database consisting of settlements and administrative decisions of the Federal Trade Commission (FTC) and consent decrees between private defendants and the Department of Justice or state attorneys general. This process yielded an additional 81 documents, which were coded in the same manner as the judicial opinions.

3. Coding. - Case coding was conducted by one team of law student research assistants at the University of Michigan Law School and another team at Columbia Law School. All research assistants attended an orientation regarding antitrust law, health care, and the details of the coding instrument, and they were given a primer on antitrust law as a reference. Initial coding at each site was conducted in a group setting to encourage questions regarding the coding instrument to be asked and to allow answers to be shared. If students subsequently encountered difficulties applying the coding instrument to particular cases, they sent queries to us via e-mail, and answers were circulated to all students at both sites. Students were given packets containing approximately twenty-five cases each; packets were constructed so that all opinions relating to the same dispute were grouped together. Students worked with printouts of the cases and were instructed to enter relevant coding numbers in the margins of the opinion next to the text giving rise to the category. To facilitate subsequent review of the quality coding and to ensure that our analysis would not become too far removed from the language of the judicial opinions, students highlighted in yellow the relevant text of all opinions coded as including any quality related categories.

After each group of cases was coded by one research assistant, it was given to a different research assistant to be checked. Checking consisted of a manual review of all coded fields and an electronic search of the opinion using LEXIS for terms such as "quality," "choice," "skill," and

23. The LEXIS search used in the COURTS file of the GENFED library was as follows: "Antitrust and date aft 1/1/85 and date bef 6/1/99 and (physician or hospital or health insur! or HMO or pharmaceutical or nursing or medical device or dentist or chiropractor or mental health)."

24. We searched LEXIS state court files separately for health care decisions involving state rather than federal antitrust law and identified 107 opinions that met our search criteria. We coded these cases in similar fashion to the federal opinions discussed in this Article and will report their content in a subsequent paper. 
"innovation" to locate quality related considerations potentially missed by the initial coder. Coding for all cases was reviewed a third time by one of us and the results were entered onto a spreadsheet for tabulation.

As a check on the initial case screening, research assistants were asked to verify that the opinions they read were in fact about both antitrust law and health care. If an opinion contained "essentially no antitrust" or "essentially no health care," it was coded as fully as possible, but removed from the database. This process eliminated an additional 446 opinions, leaving a total of 542 separate health care antitrust opinions in the final sample. Opinions relating to the same underlying dispute were grouped together for analysis of certain characteristics. The 539 opinions in our main database represent 394 separate antitrust disputes. When the 82 DOJ, FTC, and state attorney general consent decrees and other agency decisions are combined with the 31 opinions in litigated cases where public parties are plaintiffs, one gets a total of 113 enforcement agency "opinions" representing 89 separate "disputes."

\section{B. Coding Quality of Care}

The most important and difficult assessments in the coding instrument involve the classification of quality. Quality is a slippery concept, and we are unaware of previous efforts to develop a comprehensive antitrust taxonomy of quality or nonprice competition, either inside or outside of health care markets. The coding instrument therefore gathers a range of information regarding judicial beliefs about the general effects of price and quality based competition in health care markets, the specific effects of the challenged conduct, and the role various quality and nonprice concerns play in courts' analyses of particular situations.

This is not to say that antitrust law is a blank slate when it comes to quality. Indeed, one of the challenges in designing the coding instrument was the fact that antitrust lawyers, economists, medical professionals, and health services researchers have very different and often conflicting understandings of what quality means. Thomas Kauper provides a useful analysis of how antitrust law and economics typically address quality. ${ }^{25}$ Kauper starts with an appreciation of the fact that "the appropriate

25. See Thomas E. Kauper, The Role of Quality of Health Care Considerations in Antitrust Analysis, Law \& Contemp. Probs., Spring 1988, at 273, 276-80, 292-319. While there is substantial overlap between antitrust lawyers' and economists' understanding of quality, they are not always the same. Antitrust law often reflects, as a matter of pragmatic necessity, the simplest core of economic reasoning. Unfortunately, with respect to nonprice competition, there is no core consensus among economists as to how quality should be defined or understood. Economists have approached quality in a variety of ways, depending upon what type of nonprice issue is being addressed. See generally Jean Tirole, The Theory of Industrial Organization 95-115 (1988) (presenting economic approaches to product characteristics). In most economic models, it makes a substantial difference whether consumers have the same preference orderings with respect to quality characteristics (vertical quality models), or whether consumer preferences over quality vary (horizontal quality models). See id. at 96-99 (discussing vertical and horizontal 
quality of care is in most instances virtually impossible to define."26 Rather than assessing quality in an absolute sense, antitrust lawyers and economists are prone to understand quality (and other nonprice factors) in terms of their tradeoffs with more traditional price concerns. ${ }^{27}$ Kauper goes so far as to assert that " [q] uality without regard to price is a relatively meaningless concept." 28 Given that resource tradeoffs lie at the heart of the antitrust analysis, the question then becomes how these tradeoffs are made. Not surprisingly, antitrust lawyers and economists view the market as the appropriate mechanism for making tradeoffs between price and quality. From an antitrust perspective, therefore, quality becomes a dimension of the competitive process itself. "Quality, then, is not an absolute. It is the result of a competitive process in which consumers have choices, and which provides incentives to producers to improve goods and services in ways that make them more saleable."29

Needless to say, this stands in sharp contrast with the views of the medical profession. While antitrust law tends to view quality as the outcome of an economic process, health care professionals tend to view quality as the outcome of a medical process. This leads them to frame quality in absolute terms, divorced from economic context. The Institute of Medicine's 1990 definition of quality is a case in point. Without incorporating any sense of budgetary constraints or opportunity costs, the 1nstitute of Medicine (IOM) defined quality as follows: "[Q] uality of care is the degree to which health services for individuals and populations increase the likelihood of desired health outcomes and are consistent with

differentiation). Locational models are often used to examine horizontal quality competition. These models view the consumer's selection of a quality characteristic as taking place within a "product space" very similar to the "geographic space" in which the consumer clecides where to purchase a product when the purchase decision is influenced by transportation costs. See, e.g., Harold Hotelling, Stability in Competition, 39 Econ. J. 41, 45-48 (1929) (developing Hotelling's classic model of locational competition). Alternatively, Kelvin Lancaster models goods as consisting of different bundles of quality characteristics and assumes that consumers have preferences regarding the quality characteristics rather than the particular good. See Kelvin J. Lancaster, A New Approach to Consumer Theory, 74 J. Pol. Econ. 132, 133-35 (1966). Various other consumer theories simply try to incorporate consumers' preferences for quality as an aspect of individual utility and resort to general models of welfare economics. See, e.g. Michael Spence, Product Differentiation and Welfare, 66 Am. Econ. Rev. 407, 413-14 (1976) (discussing difficulties modeling consumer preferences and demand). Using these types of models, economists have tried to examine questions such as the optimum level of quality that producers should select, whether there are too few or too many products offered on the market, and the relationship between product quality and imperfect information.

26. Kauper, supra note 25 , at 276.

27. Id. ("[A]t least given limited resources, consumer decisions about quality involve tradeoffs and consideration of price.").

28. 1d.

29. Id. at 293. 
current professional knowledge." 30 These conflicting orientations toward quality lead in fundamentally different directions. The medical professional wants to impose professionally predetermined restrictions on market processes, while the antitrust lawyer strives to free the market from such restrictions, with both groups asserting their positions in the name of quality. ${ }^{31}$

Health services research offers yet another perspective on quality. As defined in the health services research literature, quality consists of both the "technical" and the "interpersonal" aspects of medical care. ${ }^{32}$ Health services researchers also allow that patients (consumers) will be concerned about the "amenities" associated with the provision of care. ${ }^{33}$ The most widely used tool to operationalize these quality concerns is Donabedian's examination of the structure, process, and outcomes of providing medical care:

Quality of care can be evaluated on the basis of structure, process or outcome. Structural data are characteristics of physicians and hospitals (e.g., a physician's specialty or the ownership of a hospital). Process data are the components of the encounter between a physician or another health care professional and a patient (e.g., tests ordered). Outcomes data refer to the patient's subsequent health status (e.g., an improvement in symptoms or mobility). ${ }^{34}$

30. 1 Comm. to Design a Strategy for Quality Review and Assurance in Med., Inst. of Med., Medicare: A Strategy for Quality Assurance 21 (Kathleen N. Lohr ed., 1990). While a useful starting point, there are a number of limitations with the 1OM approach. Most significantly, the definition does not consider the opportunity costs involved with providing increased levels of care. See R. Adams Dudley et al., The Impact of Financial Incentives on Quality of Health Care, 76 Milbank Q. 649, 652 (1998) (noting that "[t]he IOM explicitly chose to ignore resource constraints in formulating its definition of quality"). For additional discussions of the IOM definition, see Mark R. Chassin \& Robert W. Galvin, The Urgent Need to Improve Health Care Quality: Institute of Medicine National Roundtable on Health Care Quality, 280 JAMA 1000, 1001 (1998); Sisk, supra note 11 , at $688-89$; McGlynn, supra note 11 , at 7,8 .

31. Kauper again articulates the prevailing view among antitrust scholars. "There is in most cases a fundamental contradiction in the argument that quality can be enhanced through restraints among producers (providers) that significantly restrain the competitive process and result in adverse price and output effects." Kauper, supra note 25, at 293.

32. 1 Avedis Donabedian, Explorations in Quality Assessment and Monitoring: The Definition of Quality and Approaches to its Assessment 4 (1980).

33. Id. at 5. Donabedian incorporates into his definition of health care "quality" only those aspects of amenities that affect the interpersonal dimensions of medical services. Id. If one views the interaction not through the physician-patient lens, but through the provider-consumer lens, then all amenities, even those that do not directly impact the interpersonal dimensions of medical care, would be relevant to analyzing the transaction. This also helps illustrate the differences between "quality" and "nonprice" concerns. From an economic perspective, "quality" as understood by Donabedian and other health services researchers would be a subset of a broader range of relevant nonprice concerns for antitrust purposes.

34. Robert H. Brook et al., Measuring Quality of Care, 335 New Eng. J. Med. 966, 966 (1996). For a detailed discussion of the structure, process, outcome paradigm, see 1 
The health services research literature therefore refines the traditional medical approach without bridging the philosophical gulf between health care professionals and economists.

Which of these understandings of quality (antitrust economic, medical professional, or health services research) are most appropriate depends largely upon the object of the inquiry. Our challenge was to develop a defensible system of evaluating the ways in which judicial opinions struggle with-or simply ignore-quality concerns. How should one expect antitrust courts to approach health care quality? Because any serious attempt to describe, understand, or discuss quality concerns would likely resort to themes reflected in the health services research literature, the presence or absence of language characteristic of that literature may provide a clue to the intensity of judicial interest in quality. Similarly, if quality concerns were being litigated with any regularity, then expert witnesses would likely draw upon similar language and concepts, which would also frequently be evident in judicial opinions.

Alternatively, antitrust courts may attempt to bypass the unfamiliar language of health services research, preferring to rely on proxy doctrines or other conventional legal devices. Kauper suggests that antitrust courts may be just as likely to avoid as engage quality concerns in health care. ${ }^{35}$ Furthermore, Kauper argues that health care quality concerns must first be translated into economic concerns before they will register in an antitrust analysis. ${ }^{36}$ If this is true, then courts would be more likely to speak of quality in terms of actions taken to reduce malpractice liability exposure or efforts to build a general reputation for good service, rather than employing the language of health services research, because re-

Donabedian, supra note 32 , at $79-85$; see also R. Adams Dudley et al., supra note 30 , at 663-73 (applying the structure, process, outcome framework to evaluate the results of different studies on the effects of fee-for-service and HMO financial incentives on the "quality" of patient care); Daniel R. Longo et al., Consumer Reports in Health Care: Do They Make a Difference in Patient Care?, 278 JAMA 1579, 1581 (1997) (“[S] tructural variables describe the nature, type and organization of . . services . . . ; process variables address the care process .... Variables indicating the outcome of care include ... mortality and patient satisfaction."); R. Heather Palmer, Considerations in Defining Quality of Health Care, in Striving for Quality in Health Care 1, 28 (R. Heather Palmer et al. eds., 1991) ("Structural data describe features of healtb care facilities, equipment, professional and nonprofessional staff, and organization for delivery of care. Process data describe the things actually done to or for a patient. Outcome data describe the change in health status of a patient that is attributable to health care.").

35. See Kauper, supra note 25 , at 278. To the extent that the motivation to avoid quality concerns is based upon the belief that the tradeoffs implicit in quality assessment are better left to legislators tban judges, our instrument should capture this reasoning. See infra Appendix $\$ \S 5-1-7,5-1-8,5-1-9$ (coding for discussions pertaining to whether courts should be cautious applying the antitrust rules to health care because of the professional values or social imperatives at stake, or whether courts should strictly apply the antitrust rules in health care in lieu of some express legislative direction to do otherwise).

36. See Kauper, supra note 25, at 296 (arguing that the range of legitimate quality concerns under antitrust law consists of efforts to ameliorate market failures, actions that increase efficiency, and actions that would permit providers to compete more effectively). 
duced liability and increased goodwill can be described as enhancing efficiency or competitiveness. ${ }^{37}$

In constructing the coding instrument, we endeavored to be inclusive and tried not to prejudge how courts would approach quality concerns. As a result, we drew freely from all the aforementioned perspectives. A complete list of quality related factors can be found in section 5 of the coding instrument (reproduced in the Appendix). Sections 5-3, 54, and 5-5 track concerns raised in the health services literature, although the instrument bifurcates the structural component of the structure-process-outcome triad into clinical structure and firm administration. Clinical structure includes advanced technology, qualifications of physicians and other licensed health professionals, adequacy of staffing, adequacy of physical facilities, continuity of care, accreditation, and certification. Firm administration includes solvency, firm governance, provision of charity and uncompensated care, bureaucratic restrictions, grievance procedures, consumer education, and amenities. Because sophisticated methods for assessing outcome are likely inaccessible to courts, the coding instrument folds clinical outcomes into process, which includes malpractice and negligence concerns, rankings in quality surveys (report cards), qualitative success scores, provision of preventative services, product defects, and the potential for clinical innovation.

Antitrust law generally analyzes markets rather than individual firms. We therefore distinguished in the coding instrument between firm-level and market-level attributes of quality. Antitrust law is also concerned with issues of product differentiation, consumer choice, and the role of information in the efficient operation of the market. Section 5-7 of the instrument examines these concerns by coding for the range of products and services available on the market, geographic location, freedom of choice among health care providers, the market effect of information, professionalism, and the market- or system-wide dimensions of physician qualifications and the quality of health care facilities. The result is a list that we believe casts a wide net for quality concerns of interest to health care policymakers that could plausibly be present in the case law.

\section{Limitations of the Methodology}

Scholarship purporting to conduct empirical assessments of legal issues is increasingly popular. ${ }^{38}$ The term "empirical" is used to describe a variety of topics and methodologies (and, arguably, to cover a variety of

37. Id. at 302-06 (discussing how actions taken to reduce malpractice liability or create a general reputation for high quality can be framed as improving efficiency or being procompetitive for antitrust purposes).

38. For a discussion of this approach to legal scholarship, see generally Michael Heise, The Importance of Being Empirical, 26 Pepp. L. Rev. 807 (1999). For an evaluation and critique of empiricism in legal scholarship, see Lee Epstein \& Gary King, The Rules of Inference, 69 U. Chi. L. Rev. (forthcoming 2002). 
sins). ${ }^{39}$ This is a confused area of legal scholarship, with few clear norms or standards to guide researchers. There is a tendency for each new enterprise to invent its own wheel, often in a fairly ad hoc manner. In some respects we are no different. Several previous studies are comparable to our own because they also treat judicial opinions as "data" for social science purposes and subject coded characteristics to various forms of statistical analysis. ${ }^{40}$ One of us is on record expressing skepticism about efforts

39. See, e.g., Saul M. Kassin, An Empirical Study of Rule 11 Sanctions, Federal Judicial Center 8-15 (1985) (discussing federal judges' responses to survey posing Rule 11 sanction questions under certain fact patterns); Thomas E. Willging et al., Empirical Study of Class Actions in Four Federal District Courts: Final Report to the Advisory Committee on Civil Rules, Federal Judicial Center 1-5 (1996) (studying practices and effects of class certification in four federal districts between 1992 and 1994); David C. Baldus et al., Racial Discrimination and the Death Penalty in the Post-Furman Era: An Empirical and Legal Overview, with Recent Findings from Philadelphia, 83 Cornell L. Rev. 1638, 1643, 1662-75 (1998) (studying effects of victims' and defendants' race on death penalty trials in Pennsylvania); Melinda Gann Hall \& Paul Brace, Towards an Integrated Model of Judicial Voting Behavior, 20 Am. Pol. Q. 147, 147-48, 155-58 (1992) (studying judicial voting patterns in state death penalty cases); Michael Heise, State Constitutional Litigation, Educational Finance, and Legal Impact: An Empirical Analysis, 63 U. Cin. L. Rev. 1735, 1735-39 (1995) (studying school finance litigation as a variable in determining levels of state spending on education); Robert M. Lawless \& Dylan Lager Murray, An Empirical Analysis of Bankruptcy Certiorari, 62 Mo. L. Rev. 101, 102-04 (1997) (studying 611 bankruptcy certiorari petitions to determine the relationship between case characteristics and the grant of Supreme Court review); William H. Manz, Cardozo's Use of Authority: An Enpirical Study, 32 Cal. W. L. Rev. 31, 31-35 (1995) ("surveying the use of authority in all the opinions of Benjamin N. Cardozo and his contemporaries on the New York Court of Appeals and the United States Supreme Court"); John H. Merryman, Toward a Theory of Citations: An Empirical Study of the Citation Practice of the California Supreme Court in 1950, 1960, and 1970, 50 S. Cal. L. Rev. 381, 381-82 (1977) (studying the types of authority relied upon in judicial opinions); Gregory C. Sisk, Michael Heise \& Andrew P. Morriss, Charting the Influences on the Judicial Mind: An Empirical Study of Judicial Reasoning, 73 N.Y.U. L. Rev. 1377, 1380-84, 1438-51 (1998) (studying effects of judges' backgrounds on legal outcomes under federal sentencing guidelines); Robert H. Smith, Justice Souter Joins the Rehnquist Court: An Empirical Study of Supreme Court Voting Patterns, 41 U. Kan. L. Rev. 11, 11-19 (1992) (examining voting patterns of justices to assess impact of changing membership of the Court).

40. See, e.g., Gerard Anderson et al., When Courts Review Medical Appropriateness, 36 Med. Care 1295, 1296-97 (1998) (coding and statistical analysis of judicial opinions in state and federal insurance coverage cases); Mark A. Hall et al., Judicial Protection of Managed Care Consumers: An Empirical Study of Insurance Coverage Disputes, 26 Seton Hall L. Rev. 1055, 1056-59 (1996) (same); James A. Henderson, Jr., Judicial Reliance on Public Policy: An Empirical Analysis of Products Liability Decisions, 59 Geo. Wash. L. Rev. $1570,1571,1586-89$ (1991) (coding of 2517 judicial opinions in products liability cases with analysis of the type and frequency of different forms of judicial reasoning); Ann Juliano \& Stewart J. Schwab, The Sweep of Sexual Harassment Cases, 86 Cornell L. Rev. $548,549-50,555-60$ (2001) (coding and statistical analysis of 650 judicial opinions in federal sexual harassment cases between 1986 and 1996); Vicki Schultz \& Stephen Petterson, Race, Gender, Work, and Choice: An Empirical Study of the Lack of Interest Defense in Title VII Cases Challenging Job Segregation, 59 U. Chi. L. Rev. 1073, 1089-95 (1992) (coding and statistical analysis of federal judicial opinions between 1965 and 1989 in Title VII cases); Peter D. Jacobson et al., The Role of the Courts in Shaping Health Policy: An Empirical Analysis, 29 J.L. Med. \& Ethics 278, 280-86 (2001) (coding judicial 
to treat judicial opinions in an overly quantitative manner. ${ }^{41}$ The key question in our minds is whether an appropriate fit exists among the problem being examined, the methodologies employed, and the specific questions that the researcher seeks to answer. For many purposes, we doubt that statistical methods substantially improve on traditional forms of legal analysis, although the effort systematically to examine a broad sweep of cases can bring new information to light. We therefore consciously designed our coding instrument to ensure that extracted data would not become too far removed from the underlying text of the opinions. All of our quality related codes are tied to highlighted passages in the judicial opinions, and we analyze and present our results in light of the context in which these discussions take place.

In assessing the strength and limitations of our methodology, the objective of the coding exercise must be kept in mind. The coding exercise is not intended as a means of determining "what the law is." 42 Instead, each opinion is treated as a discrete unit of analysis, a social artifact recording how a particular legal decisionmaker frames, understands, and decides a problem. In other words, the opinions are treated as data, not precedent. Since the opinions are not being treated as sources of law, the instrument does not differentiate between appellate and district court opinions. Each opinion is accorded the same weight, an approach antithetical to the structured hierarchy that is normally the law. ${ }^{43}$

opinions and assessing the relationship between types of judicial reasoning and case outcomes).

41. See William M. Sage, Judicial Opinions Involving Health Insurance Coverage: Trompe L'Oeil or Window on the World?, 31 Ind. L. Rev. 49, 61-68 (1998) (identifying small sample size, long time lags, selection bias, publication bias, and unstated rationales as limitations of the judicial dataset).

42. The principal difference between traditional legal research to determine "the law" and empirical studies of judicial opinions is that, particularly with respect to federal cases, the former is a much more selective enterprise. Legal treatises, casebooks, and law reviews typically focus their attention on disputes that reach the highest federal courts, and tend to ignore (often for good reason) the larger landscape. Decisions by the U.S. Supreme Court are authoritative. Decisions by federal appeals courts come next in the hierarchy, and certain courts are accorded substantial deference even if their rulings are not strictly binding on litigants in other jurisdictions. Decisions in federal district court, the lowest rank, have precedential value only for other federal courts in the same district, although such opinions may be considered persuasive by courts elsewhere if they involve comparable facts or if authored by a particularly respected judge. Because our sample of cases includes judicial opinions from each tier of the court system and our coding instrument makes no attempt to differentiate tbe persuasiveness of the legal analysis, our methodology is an imperfect guide to what the law is.

43. Some may still want to privilege the views of appellate courts, and it is possible to reconcile such desires with our study methodology. We examine judicial opinions over a fifteen-year period. One can view a district court opinion as reflecting the wisdom and advice of past appellate court decisions. As such, the district court opinion is a lagging indicator of appellate court developments. Over time, one should be able to observe the influence of particular appellate decisions as they are followed in subsequent cases. If an appellate opinion comes up with an innovative means of addressing quality claims, that would get coded not simply for tbe one appellate case, but for every subsequent occasion 
The coding exercise should be able to shed light on two distinct sets of questions. First, what are the core characteristics of medical antitrust litigation-who is suing whom, on what theories, and with what outcomes? Second, and more central to our long term project, what role do considerations of quality and nonprice competition play in medical antitrust litigation? In assessing these results, the reader needs to be sensitive to a number of possible limitations in our study design.

Any study of legal disputes raises questions of selection bias. Why are some antitrust cases brought while others are not? Which cases are likely to settle and which are likely to be litigated? Which cases are likely to be appealed and which will end at the trial court level? Not surprisingly, our study reveals the full pyramid of federal judicial activity. Federal district courts accounted for 347 of the 542 opinions in our database $(64 \%)$, federal appeals courts for 191 opinions (35\%), and the Supreme Court for merely 4 opinions $(1 \%){ }^{44}$

While one must consider the implications of a possible settlement bias in our sample, this issue may be less pronounced for us than for other researchers. By including all medical antitrust cases that generate an opinion, our sample includes cases that are litigated through final verdict and appeal as well as cases that settle after the issue in question is resolved by the court. ${ }^{45}$ As a result, the "settled"/"not settled" distinction

the same reasoning was invoked. Alternatively, if one believes that legal changes take place through periodic flashes of judicial insight, our process of highlighting and subsequently reviewing the text of quality related codes should detect these watershed events.

There are additional reasons for heing particularly concerned with district court cases. In assessing judicial capacity to address quality and nonprice concerns, we are interested in the law in practice. Medical antitrust litigation is fact intensive, product and geographic markets in health care are frequently small, and repeat players are few. Moreover, to the extent that a central part of our ohjective is to examine how judges think about quality and nonprice concerns, a focus on judicial opinions, and particularly district court opinions, is both natural and expected.

44. Cal. Dental Ass'n v. FTC, 526 U.S. 756 (1999); Summit Health Ltd. v. Pinhas, 500 U.S. 322 (1991); Patrick v. Burget, 486 U.S. 94 (1988); FTC v. Ind. Fed'n of Dentists, 476 U.S. 447 (1986). Two other significant Supreme Court opinions involving health care shortly preceded our sampling period and unquestionably exerted influence over the cases we studied. See Jefferson Parish Hosp. Dist. No. 2 v. Hyde, 466 U.S. 2 (1984); Arizona v. Maricopa County Med. Soc'y, 457 U.S. 332 (1982).

45. George Priest and Benjamin Klein have illustrated how "disputes selected for litigation (as opposed to settlement) will constitute neither a random nor a representative sample of the set of all disputes." George L. Priest \& Benjamin Klein, The Selection of Disputes for Litigation, 13 J. Legal Stud. 1, 4, 17-20 (1984). Instead, when the assumptions of the Priest-Klein model are satisfied, litigated disputes tend to group in a fairly symmetric manner around the controlling "standard of decision," whatever that standard may be. Id. at 4,14-15. It is difficult to assess fully the selection bias in our sample. Unlike Priest and Klein's binary distinction between "litigated" cases (only those cases where a verdict is rendered) and "settlements" (all other cases), our sample includes a variety of legal disputes: motions to dismiss, motions for summary judgment, new trial motions, and appeals. As such, our sample can be viewed as multiple Priest-Klein clusters around a range of different "decision standards." Id. We do not pretend that this collection produces a full representative sample, but it should produce a fuller, although perhaps 
does not map well onto our case sample. One might be more concerned about possible selection bias if one believed that cases raising different types of quality claims were systematically more likely to settle and therefore escape our notice. We do not believe this to be the case. The nuanced understandings of quality and nonprice claims that would engender such settlement practices do not yet exist in the literature or case law, and are not part of the folklore among experienced practitioners. ${ }^{46}$

A more serious problem for us may be a publication bias rather than a settlement bias. We examine only those cases resulting in a written opinion. A case may settle before an opinion issues, or a case may work its entire way through the legal process and result in a jury verdict without an accompanying opinion. The seriousness of this limitation is difficult to assess. By relying upon LEXIS rather than the official reporters, we capture and code many cases not formally destined for "official" publication. In addition, cases treating novel issues and cases creating new law are the strongest candidates for publication. To the extent that sophisticated discussions of quality and nonprice competition fall into these categories, we are relatively confident that they will end up in our sample.

A related selection problem is that legitimate health care quality concerns may simply not be litigated. Antitrust litigation is expensive. If litigating quality related claims requires expert testimony or detailed economic analysis, such claims would more often be pursued in cases where the stakes are high and the litigants well funded. The fact that, compared to price claims, quality claims are likely to represent higher risk strategies with lower expected payoffs would tend to accentuate this effect. Alternatively, because contemporary antitrust law does not create many obvious placeholders for nonprice concerns, quality may be litigated under alternative guises. It is difficult for any coding instrument to detect claims that are not brought, or that are brought (or resolved) in camouflaged doctrinal form. As a partial solution, our coding instrument liberally employs categories for "other" and "unspecified" quality concerns to detect some of these instances, and our review of the cases was done with these possibilities in mind. ${ }^{47}$

Various strategic biases may also be in play. In general, empirical assessments of litigation from an "objective" social science perspective

noisier sample than would result from a focus on a narrow subset of disputes. A more serious issue for us may be accounting for the biases attributable to the factors influencing whether or not a judicial decision or legal outcome results in a puhlisbed opinion. We explore the extent to which the cases in our sample comply with or deviate from the PriestKlein hypothesis. See infra notes 129-133 and accompanying text.

46. Uncertainty may discourage settlement because the parties are less likely to have convergent expectations about the probability of particular outcomes and therefore the value of the case. On the other hand, greater uncertainty may increase the incentives of risk averse parties to settle claims. Which effect predominates may determine whether quality claims are under or overrepresented in a sample of litigated (unsettled) cases. For further discussions of settlement models, see infra notes 129-138 and accompanying text.

47. See, e.g., infra Appendix $\$ \$ 5-47,5-6-3,5-7-9$. 
often underappreciate the extent to which outputs of the legal process are determined by adversarial proceedings fraught with strategic behavior, including at the stage of drafting a judicial opinion. Specifically, not all "quality" claims are equally meritorious. There is a long history in antitrust law of quality claims being used to rationalize behavior that is patently anticompetitive. Quality may even be invoked strategically to confuse issues or introduce greater uncertainty into the litigation. Judges also have various motives for writing opinions, and do not necessarily reveal the true reasons for their decisions in text. ${ }^{48}$ Our coding instrument cannot detect strategic behavior on the part of litigants or judges, although information we adduce about the scope of legal analysis and comparisons between quality claims and case outcomes can help shed light on this question.

Finally, we have kept statistical analysis to a minimum in reporting our results. Formal predictive models should be reserved for situations in which the specific legal question examined in each case is similar. ${ }^{49}$ Our sample, on the other hand, involves every type of antitrust claim. Nevertheless, several comparisons and associations we report require statistical validation. The general model for these analyses used simple bivariate cross-tabulations of categorical data. Statistical significance of observed relationships was determined using tests of association, including chisquare tests. Where coded information involved multiple but not mutually exclusive categories, we examined cross-tabulations that permitted overlapping responses. Results were significant at $p \leq .05$ unless otherwise specified.

\section{EMpirical Results}

We divide the results of our case review into three parts: information about the universe of private disputes involving the health care industry that arise under federal antitrust law, information pertaining to the formal antitrust enforcement activities of public agencies, and, finally, specific observations about judicial and enforcement agency treatment of nonprice competition and health care quality.

We report some results in terms of the number of judicial opinions in our sample $(\mathrm{N}=542)$ that exhibit particular characteristics. These include the procedural question giving rise to a particular judicial determination (for example, summary judgment, motion to dismiss, appeal of

48. See, e.g., Richard A. Posner, What Do Judges and Justices Maximize? (The Same Thing Everybody Else Does), 3 Sup. Ct. Econ. Rev. 1, 25-30 (1993) (describing how the motivations of judges affect judicial opinions).

49. Anderson et al., supra note 40; Juliano \& Schwab, supra note 40; and Schultz \& Patterson, supra note 40 , fall into the category of collecting and analyzing comparable legal questions and are more appropriate candidates for the statistical methods those authors employ. Of course, similar methods of analysis could apply to subsets of a heterogeneous sample if the subset contained sufficiently analogous legal questions and was sufficiently large. 
jury verdict), the resolution of each such question (both the party favored by the court and the specific remedy granted or withheld), the alleged violations of antitrust law considered by the court, and the type of legal analysis performed. However, in order to avoid skewing our conclusions toward parties or fact patterns that for one reason or another gave rise to protracted litigation that occupied the courts over a series of opinions, we report other results (for example, characteristics of the parties, the business conduct involved, the geographic market implicated) in terms of the number of distinct disputes $(\mathrm{N}=394)$ represented by the opinions in our sample. ${ }^{50}$ Where dates were needed for disputes as opposed to individual opinions, we used the date of the first opinion generated by the dispute.

\section{A. Private Medical Antitrust Litigation}

Federal antitrust law provides several enforcement avenues: criminal and civil enforcement by the Department of Justice (DOJ), civil administrative enforcement by the Federal Trade Commission (FTC), civil enforcement by state attorneys general, and civil actions by private parties with the prospect of treble damages (as well as defensive antitrust pleadings by private parties in civil litigation). As might be expected, public enforcement concentrates on conduct deemed by the government most likely to threaten social welfare, and accordingly it is likely to attract greater attention from legal scholars. ${ }^{51}$

Empirical evidence reveals a different picture. Between 1985 and 1999, private antitrust suits dominated public ones in terms of the number of cases resolved by courts. In our review, litigation by public enforcement agencies generated only 22 of the 394 health care antitrust disputes we identified $(6 \%)$. By contrast, private plaintiffs were involved in 372

50. Of the disputes associated with multiple opinions, 5 disputes generated 5 opinions, one dispute generated 4 opinions, 22 disputes generated 3 opinions, and 78 disputes generated 2 opinions. These numbers are relatively small because, as noted above, we only coded opinions that, considered in themselves, involved both health care and antitrust law. If one includes opinions on procedural and other matters that do not meet our test for relevance, one dispute (In re Brand Name Prescription Drugs Antitrust Litig., 123 F.3d 599 (7th Cir. 1997)) generated 42 opinions, 2 disputes generated 8 opinions, 2 disputes generated 7 opinions, 4 disputes generated 6 opinions, 5 disputes generated 5 opinions, 8 disputes generated 4 opinions, 28 disputes generated 3 opinions, and 117 disputes generated 2 opinions.

51. This is at least true for public litigation. By contrast, the underbelly of public enforcement, which consists of consent decrees, business review letters, and advisory opinions, is often neglected. See infra Part II.B. This is a potentially serious oversight. While the figures are a little dated, it is reported that between 1973 and 1981 some $92 \%$ of civil antitrust actions ended in the entry of consent decrees. Janet L. McDavid et al., Antitrust Consent Decrees: Ten Years of Experience Under the Tunney Act, 52 Antitrust L.J. 883, 883 (1983). Moreover, as antitrust enforcers act increasingly as regulators rather than prosecutors, what happens outside of the courtroom may be more iniportant than what is litigated and reported in judicial opinions. The DOJ's and FTC's regulatory roles are explored in greater detail infra notes 155-160 and accompanying text. 
disputes $(94 \%)$. Therefore, we present results relating to private litigation before turning to public antitrust enforcement activities.

1. Parties. - Most private cases involved more than one plaintiff and more than one defendant. Physicians in solo or small group practice were by far the largest plaintiff group, accounting for 195 private disputes $(53 \%)$. Pharmaceutical companies and medical device manufacturers were the second largest plaintiff group (45 disputes; $12 \%$ ), followed by nonphysician health professionals such as nurses and chiropractors (26 disputes; $7 \%$ ) and hospitals (23 disputes; $6 \%$ ). All but one of the disputes with nonphysician health professionals as plaintiffs occurred in the first five years of the study period (1985-1989). Hospitals constituted the largest defendant pool (225 disputes; $61 \%$ ), followed by solo or small group physicians (124 disputes; 33\%). ${ }^{52}$ Professional associations served as plaintiffs in 11 disputes (3\%), and as defendants in 24 disputes (6\%). Large physician groups were plaintiffs in only 5 disputes $(2 \%)$ and defendants in 9 disputes (2\%). Although there are 17,000 nursing homes in the United States, and long-term care accounts for approximately $\$ 90$ billion annually in spending, ${ }^{53}$ a trivial amount of antitrust litigation involved nursing homes ( 2 disputes as plaintiffs; 2 disputes as defendants).

For reasons that will become clear below, the most common plaintiffdefendant pairing in our data pits physicians against hospitals (166 disputes; $45 \%$ ), and the second most common pairing pits physicians against other physicians (105 disputes; 28\%). Hospitals sued each other far less often than they were sued by physicians (17 disputes; $5 \%$ ) and even more rarely sued physicians (7 disputes; $2 \%$ ), reflecting the historical relationship between the two in which hospitals treated physicians as customers rather that co-producers because of physicians' control over hospital use by patients. ${ }^{54}$

Pharmaceutical companies, medical device manufacturers, and other health care suppliers became embroiled in litigation from time to time as both plaintiffs ( 59 disputes; $16 \%$ ), and defendants (57 disputes; $15 \%$ ), most of the time against one another (38 disputes; $10 \%$ ). Disputes with pharmaceutical company defendants increased from 7 in 1985-1989 to 21 in 1995-1999. 1t was rare for providers of medical goods (e.g., pharmaceutical companies) and providers of medical services (e.g., hospitals)

52. Because plaintiffs commonly sue more than one defendant, the number of defendants in our sample greatly exceeded the number of distinct disputes.

53. See Robert Pear, U.S. May Ease Rein on Nursing Homes, N.Y. Times, Sept. 5, 2001, at A1; Katharine Levit et al., Health Spending in 1998: Signals of Change, Health Aff., Jan./Feb. 2000, at 124, 125 (reporting that $\$ 87.8$ billion was spent on nursing homes in 1998). One possible explanation is that long-term care is chronically underfunded, with state Medicaid agencies financing approximately half of expenditures. As a result, few competitors have sought to serve that sector, and nonprofit organizations still account for nearly half of nursing homes (this may be changing as the aging population creates greater paid demand for these services). Perhaps most importantly, affiliations with nursing homes are not important to most physicians' livelihoods.

54. Paul Starr, The Social Transformation of American Medicine 161-69 (1982). 
to square off against one another. Part of this is attributable to rules of antitrust standing that generally preclude suits by indirect as opposed to direct purchasers. ${ }^{55}$ Another part may reflect the relative paucity of cases in our sample from vertically integrated sectors of health care markets, even though the extent of integration is increasing with the growth of managed care. One exception to this claim was In re Brand Name Prescription Drugs Antitrust Litigation, a dispute that was prompted by contractual ties among health insurers, hospitals, and pharmaceutical companies through pharmacy benefit managers (PBMs), which were challenged by independent pharmacies as unlawful price discrimination. ${ }^{56}$

Two additional observations are worth making from these data. First, in the rapid transition to managed care over the time period studied, insurance companies, HMOs, and other financing intermediaries were more likely to be involved in private litigation as defendants (61 disputes, $16 \%$ ) than as plaintiffs (19 disputes; $5 \%$ ). The most common plaintiffs in cases with insurance related defendants were physicians (19 disputes; $5 \%$ ), followed by other insurance related organizations (14 disputes; $4 \%$ ). Second, because physicians were the most common plaintiffs and hospitals the most common defendants, a lot of antitrust litigation involved for-profit plaintiffs suing nonprofit defendants (89 disputes; 24\%). ${ }^{57}$ Private, nonprofit organizations were seldom plaintiffs in the cases we studied (18 disputes; $5 \%$ ).

2. Business Conduct. - What types of commercial arrangements lead to antitrust litigation in health care? The business conduct at issue in the disputes we reviewed is shown in Figure 1, which compares private plaintiffs with public enforcement (combined litigation and settlements). In

55. A private antitrust plaintiff faces a number of possible hurdles in terms of standing and injury requirements. Private plaintiffs must suffer some form of antitrust injury. Brunswick Corp. v. Pueblo Bowl-O-Mat, Inc., 429 U.S. 477, 489 (1977). In addition, plaintiffs must suffer an individual injury to their "business or property," 15 U.S.C. $\S 15$ (a) (1994), that is of a direct rather than an indirect nature. Illinois Brick Co. v. Illinois, 431 U.S. 720, 735 (1977). These rules reflect an effort to achieve a difficult balance. The policy objective is to align the private interests of those granted standing with the public interests of the antitrust laws and to ensure that the entities granted standing have sufficient incentives to pursue valid claims, while at the same time avoiding the possibility that the antitrust laws themselves are coopted to serve anticompetitive ends in the hands of one competitor against another. For a general discussion of antitrust standing, see Hovenkamp, supra note $3, \S \S 16.2-16.6$. The issue of whether these private standing doctrines have been effective in presenting and framing issues in a manner that advances the public interest in medical antitrust cases is addressed infra note 146 and accompanying text.

56. 123 F.3d 599 (7th Cir. 1997). The appeal primarily involved claims under section 1 of the Sherman Act, 15 U.S.C. $\$ 1$, alleging a price fixing conspiracy by drug manufacturers. Id. at 602 .

57. Approximately $60 \%$ of acute care hospitals in the United States are private, nonprofit organizations. Bradford H. Gray, Hospital Ownership Form and Care of the Uninsured, in The Future U.S. Healthcare System: Who Will Care for the Poor and Uninsured? 207, 208 (Stuart H. Altman, Uwe E. Reinhardt \& Alexandra E. Shields eds., 1998). 
private litigation, $62 \%$ of the disputes involved dealings between physicians and hospitals, and followed two dominant patterns. The most common type of private claims involved staff privileges (129 disputes; $35 \%$ ), with a physician denied membership on a hospital medical staff suing the hospital and the staff physicians involved in the denial alleging that the action was taken to prevent competition from the newcomer. ${ }^{58}$ (Some staff privileges disputes involve current members of the medical staff whose privileges are curtailed or revoked, rather than prospective members). The second, related pattern challenges a hospital's decision to grant an exclusive contract to one physician or physician group to provide professional services in a department of the hospital, such as an emergency room or radiology suite (106 disputes; $28 \%$ ). ${ }^{59}$ Of the 143 disputes that did not fall into one of these two categories, corporate combinations (mergers and joint ventures) were at issue in 23 disputes, insurance arrangements were at issue in 50 disputes, 30 disputes involved information, and 62 disputes involved other matters. ${ }^{60}$ The information cases included matters such as membership decisions by professional associations, accreditation decisions by private self-regulatory organizations, restrictions imposed by professional bodies on advertising and marketing activities by members, and sharing information among competitors. ${ }^{61}$

Figure 2 shows the distribution of cases over time. ${ }^{62}$ The total number of disputes was essentially constant from the first period studied

58. The "medical staff" of a hospital consists of the physicians who treat patients at that hospital, and is typically a self-governing body independent of the hospital's corporate organization. Most American hospitals have an "open medical staff," meaning that any qualified physician can seek the privilege of admitting patients to and caring for patients at that hospital. Membership on a medical staff is usually determined by a committee of the current members, who tend to be physicians in private practice in the community. Barry R. Furrow et al., Health Law 795-96 (4th ed. 2001). Because new applicants to a medical staff are judged through collective action by their potential competitors, medical staff disputes map easily onto the template of possible Sherman Act section 1 violations. See, e.g., Patrick v. Burget, 486 U.S. 94, 105-06 (1988) (finding that medical staff admissions are not sheltered by the state action doctrine from antitrust enforcement in the absence of active state supervision, and upholding a nearly $\$ 2$ million judgment in favor of a surgeon denied staff privileges); see also Health Care Quality Improvement Act of 1986, 42 U.S.C. $\$ \$ 11,101-11,152$ (1994) (granting antitrust immunity to medical staff admission processes that meet certain standards).

59. Approximately two-thirds of the exclusive contracting disputes followed this physician-hospital pattern. The remaining one-third of exclusive contract cases involved pharmaceutical companies, other medical suppliers, or insurance companies entering into exclusive relationships rather than hospitals.

60. Approximately $10 \%$ of the cases involved more than one category of conduct, so that the sum of the private cases according to business conduct exceeds 372 .

61. See infra notes $199-208$ and accompanying text.

62. Because litigation is time consuming, it may take several years for a dispute to generate a published judicial opinion. The Georgetown Antitrust project reports the mean length of private antitrust cases generally to be 24.9 months (just over two years) from filing to termination, with the median length of 16.6 months (just under a year and a half). Salop \& White, supra note 15 , at 10. NERA reports an average time of nearly nineteen months between filing and disposition. NERA, Antitrust Report, supra note 16, 
Figure 1: Business Conduct at Issue

Private Enforcement

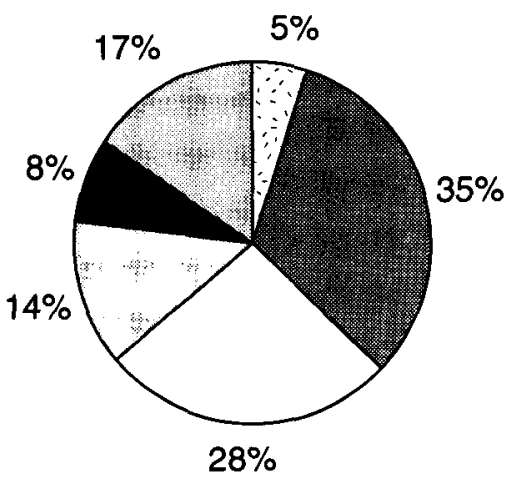

Corporate Combinations

Staff Privileges

Exclusive Contracting

EInsurance

Information

Other

Public ENForCEMENT

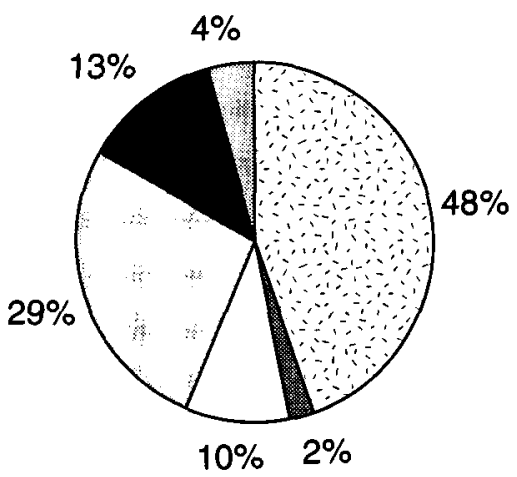

Corporate Combinations

Staff Privileges

$\square$ Exclusive Contracting

回Insurance

Information

圆Other

(1985-1989) to the last (1995-1999). Staff privileges cases declined from 51 in 1985-1989 to 34 in 1995-1999, probably reflecting the facts that very few of these cases are decided in favor of plaintiffs and legislation making it even harder for plaintiffs to prevail was enacted in $1986 .{ }^{63}$ Information cases also decreased in frequency from the earliest to the most recent part of the study period. Specifically, claims involving private credentialing and conduct by professional organizations-both physician dominated categories-declined over time, providing further support for the erosion of physicians' economic power in recent years. On the other hand, exclusive contracting cases increased slightly over time (although the difference is not statistically significant), overtaking staff privileges

at 51 . Regardless, the litigation process is highly variable, so time series data should be interpreted cautiously.

63. Health Care Quality Improvement Act, 42 U.S.C. $\$ \S 11,101-11,152$ (making it more difficult to sue doctors successfully by granting qualified immunity to doctors engaged in a peer review process). 
cases as the most common fact pattern in 1995-1999. In addition, rising pharmaceutical and medical product litigation led to an increase in "other" cases in 1995-1999.

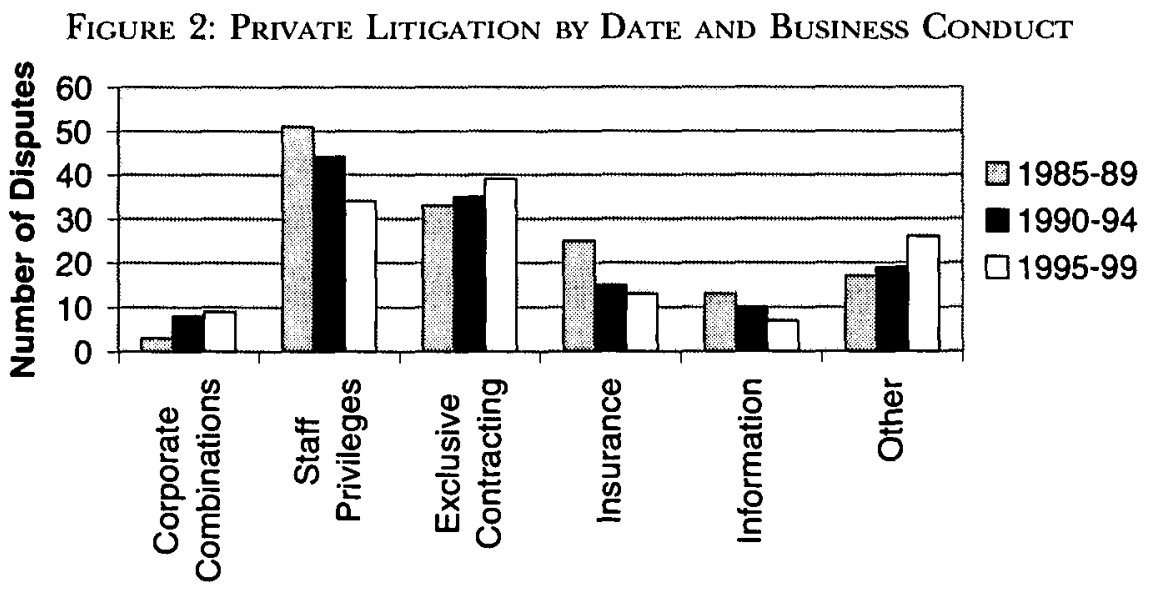

Type of Conduct

Our data show some impact of the horizontal consolidation (for example, large hospital systems) and vertical integration (for example, ventures between insurance companies and health care providers) that have been prominent features of the health care landscape of the last decade. ${ }^{64}$ Including public litigation (private challenges to mergers are uncommon), disputes involving corporate combinations rose from 6 in 1985-1989 to 15 in 1995-1999. Despite managed care, insurance cases have decreased over time. While case involving contractual terms set unilaterally by defendants (mostly insurance companies) generated 6 disputes in both 1985-1989 and 1995-1999, disputes over noncontractual payer standards and practices dropped sharply from 14 in 1985-1989 to 2 in 1995-1999. A possible explanation for this is that the latter category frequently involved insurers placing limits on coverage of services by nonphysician health professionals such as chiropractors, raising concerns that physicians were conspiring with one another and with insurers to exclude their competitors. These cases have faded, while contract of adhesion cases have not, because managed care has increased the power of insurers and allowed them to dictate terms to physicians rather than vice versa. ${ }^{65}$

64. See generally James C. Robinson, The Corporate Practice of Medicine 63-210 (1999) (describing patterns of integration and consolidation); William M. Sage, "Health Law 2000": The Legal System and the Changing Health Care Market, Health Aff., Fall 1996, at 9, 15-24 (describing the legal consequences of integration and consolidation in health care).

65. The change over a relatively short period of time is fairly dramatic. Compare Va. Acad. of Clinical Psychologists v. Blue Shield of Va., 624 F.2d 476, 485 (4th Cir. 1980), 
3. Geography. - The physical location of antitrust disputes has important legal and public policy implications. For several reasons, one might expect more antitrust activity in health care than in other sectors of the economy, with that activity concentrated in smaller geographic markets. First, it is more difficult to transport services than to transport goods. Therefore, geographic markets for care by physicians, hospitals, and other service providers tend to be smaller than for manufactured items such as pharmaceuticals and durable medical equipment. ${ }^{66}$ Second, the importance of coordination in health care service delivery enhances the need for familiarity among the participants, and therefore geographic proximity. Third, the professional nature of health care increases the role of informal information networks based on personal relationships. Fourth, patients requiring health care are often sicker and less mobile than is the case for most services in the general economy. These aspects of health care reduce demand and supply substitution, making it more likely that producer concentration will confer market power or that collusion might arise, provoking an antitrust complaint. Smaller, rural markets also have been the focus of efforts by the health care industry to obtain legislative relief from antitrust enforcement on the grounds that hospitals and physicians in those areas are "failing firms" or perhaps even "natural monopolies," combining or acting in concert simply in order to survive economically. ${ }^{67}$

where the court was concerned about the extent to which physicians might be powerful enough to co-opt the independent decisionmaking authority of the payor and exploit it towards anticompetitive ends, with Ambroze v. Aetna Health Plans of N.Y., No. 95 CIV. 6631 (DLC), 1996 U.S. Dist. LEXIS 7274, at *13-*14 (S.D.N.Y. May 28, 1996), vacated by No. 96-7778, 1997 U.S. App. LEXIS 1048 (2d Cir. Jan. 24, 1997), where the plaintiff physicians' theory of the case was that managed care plans are so powerful that they can dictate contractual terms to physicians that might impair their ability to exercise independent professional judgment.

66. See Hovenkamp, supra note $3, \S 3.6 \mathrm{~b}$ (discussing geographic markets for stationary goods and services). One effect of managed care has been to expand geographic markets for services by transporting customers to the service. For example, some managed care organizations give patients strong financial incentives to utilize more distant hospitals, especially for specialized services (so-called "tertiary care" or "quaternary care") such as cancer care or organ transplantation. This ability has been central to the geographic market definition and market power analysis in several recent hospital merger cases. See, e.g., FTC v. Tenet Health Care Corp., 186 F.3d 1045, 1049-55 (8th Cir. 1999) (citing increasing tendency of managed care plans to "steer" patients in justifying a broader geographic market than defined by district court and therefore reversing district court's grant of preliminary injunction blocking defendants' hospital merger).

67. Most of this legislative activity has taken place at the state level. Before state law can extend antitrust immunity to private actors, however, it must satisfy the requirements of the state action doctrine. See U.S. Gen. Accounting Office, Pub. No. HEHS-94-220, Health Care: Federal and State Antitrust Actions Concerning the Health Care Industry 10-13 (1994) (detailing efforts of states to grant hospitals and other health care providers immunity under state action doctrine); Fred J. Hellinger, Antitrust Enforcement in the Healthcare Industry: The Expanding Scope of State Enforcement, 33 Health Services Res. $1477,1480-86$ (1998) (summarizing recent activities of states that have attempted to exempt health care conduct from antitrust liability under state action doctrine). 


\section{Figure 3: Geographic Markets of Private Disputes}

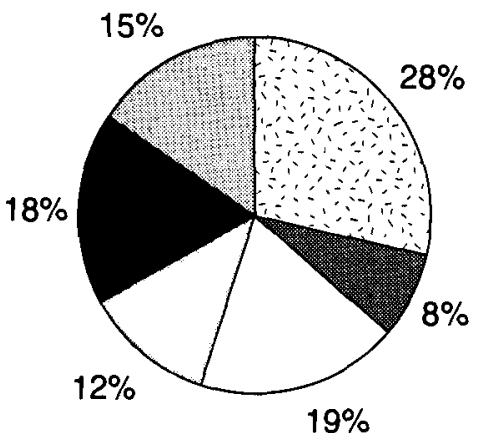

$\square$ Small City or Town
Rural Area
$\square$ Large City
$\square$ Suburb
S State or Regional
National

Our data show a wider geographic range of antitrust activity than the preceding analysis would predict (see Figure 3), with litigation seeming to track prosperity and financial resources as much as any other factor. Smaller market areas accounted for 139 disputes (37\%); larger market areas for 233 disputes $(63 \%){ }^{68}$ Setting aside disputes occurring in statewide, regional, national, or global markets, most of which involved health care goods rather than services, nearly as many antitrust disputes arose in large cities and suburbs as in smaller communities. Suburban locations accounted for 46 disputes (12\%), raising the possibility that increased competition and the restructuring of economic relations that accompanies it are as likely as diminished competition to lead to antitrust litigation. ${ }^{69}$ Rural areas generated only 30 disputes $(8 \%)$, far less than political rhetoric would suggest. The distribution of disputes between larger and smaller market areas was stable over the time period we studied. However, controversies in large cities were less common in 1985-1989 (11 disputes) than in 1995-1999 (28 disputes), while those in suburban areas were less common in 1995-1999 (10 disputes) than in 1985-1989 (21 disputes).

68. We defined geography by locating in an atlas the businesses whose conduct prompted antitrust litigation. Cities with populations less than 100,000 , not within the metropolitan area of a larger city, were deemed "small." Towns with populations less than 10,000 , not clustered with other towns of similar or larger size, and areas with diffuse populations, were deemed "rural." Towns within the metropolitan area of cities with populations greater than 100,000 were deemed "suburbs." Some disputes involving professional associations or governments were judged "statewide" or "regional." Disputes involving manufactured goods were judged "statewide," "regional," or "national/global" depending on the circumstances. Some cases involved conduct taking place across different economic markets. The existence of multiple coding explains why the coded categories slightly exceed the number of total disputes.

69. Prior to the health care cost crisis of the 1980s, emerging suburbs were natural locations for new health facilities. These locations benefited from rising real estate values and low charitable care loads and could predictably cover expenses with payments from Medicare and private insurers. More recently, private managed care and Medicare's prospective payment system, implemented in 1982, subjected these organizations and the physicians who practiced in them to a much harsher financial environment. See Furrow et al., supra note 58 , at $695-98$. 


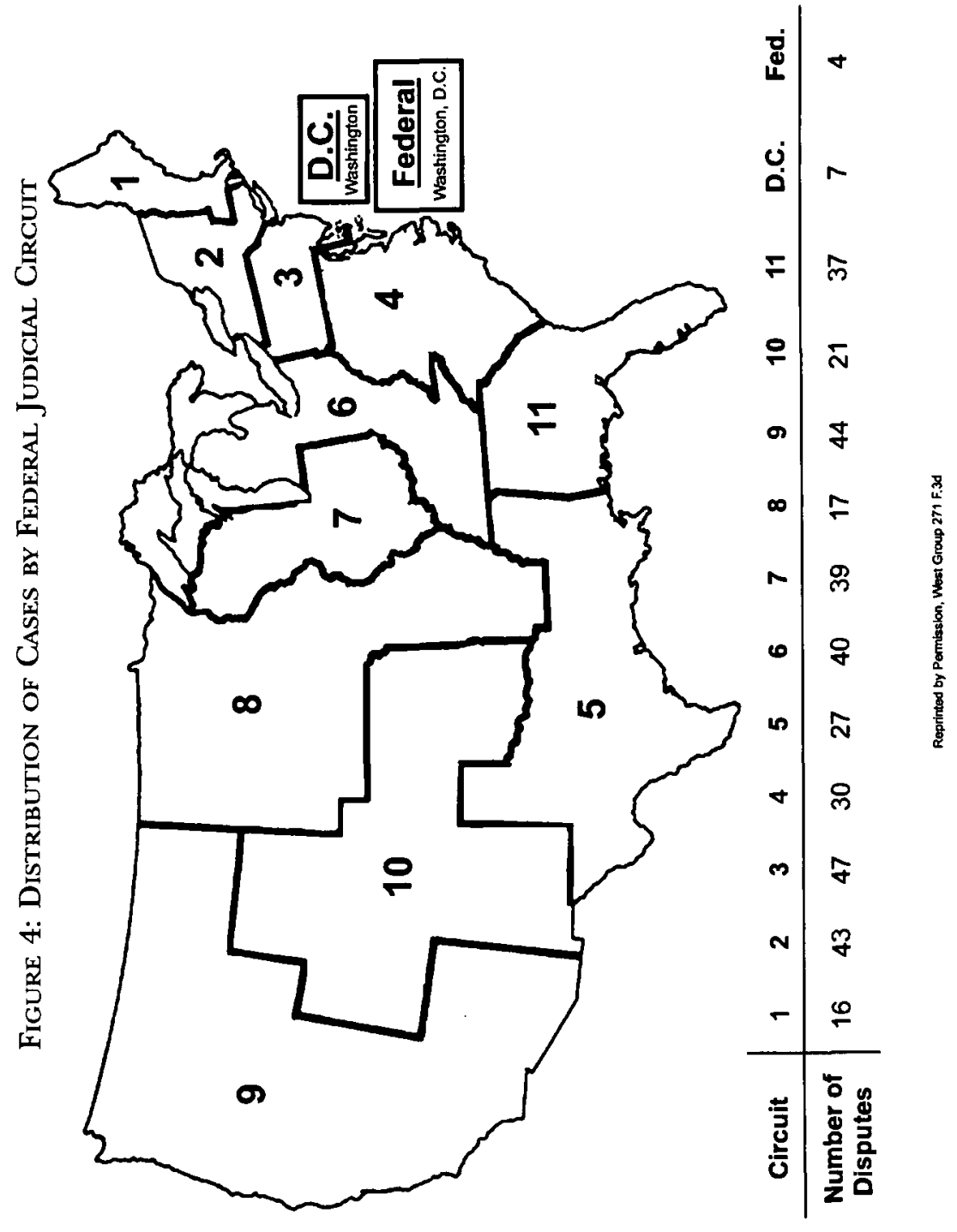


Dividing the cases according to business conduct, nearly half of staff privileges disputes involved small cities or towns $(57 ; 44 \%)$, with most of the remainder split about evenly between large cities $(25 ; 20 \%)$ and suburbs $(23 ; 18 \%)$. Exclusive contracting disputes were more broadly distributed, with the hospital related cases largely resembling staff privileges cases, but with the pharmaceutical and insurance related exclusive contracting cases implicating larger geographic markets. Approximately $10 \%$ of staff privileges and exclusive contracting cases involved rural areas.

4. Court. - The distribution of cases among the federal appellate circuits in the United States is given in Figure 4. The greatest number of cases arose in the Third, Second, and Ninth Circuits, and the fewest in the First and Eighth Circuits. Dividing cases according to business conduct (see Figure 5), staff privileges disputes were concentrated in the Fifth, Eighth, and Eleventh Circuits, and exclusive contracting disputes were concentrated in the Fourth, Sixth, and Ninth Circuits. These differences basically track regional variations in the structure of health care delivery and in the competitiveness of hospital markets. Not surprisingly, courts in the Second and Seventh Circuits heard the most cases involving business conduct other than staff privileges or exclusive contracting, with many of these disputes relating to pharmaceuticals or other medical products.

Figure 5: Business Conduct by Court

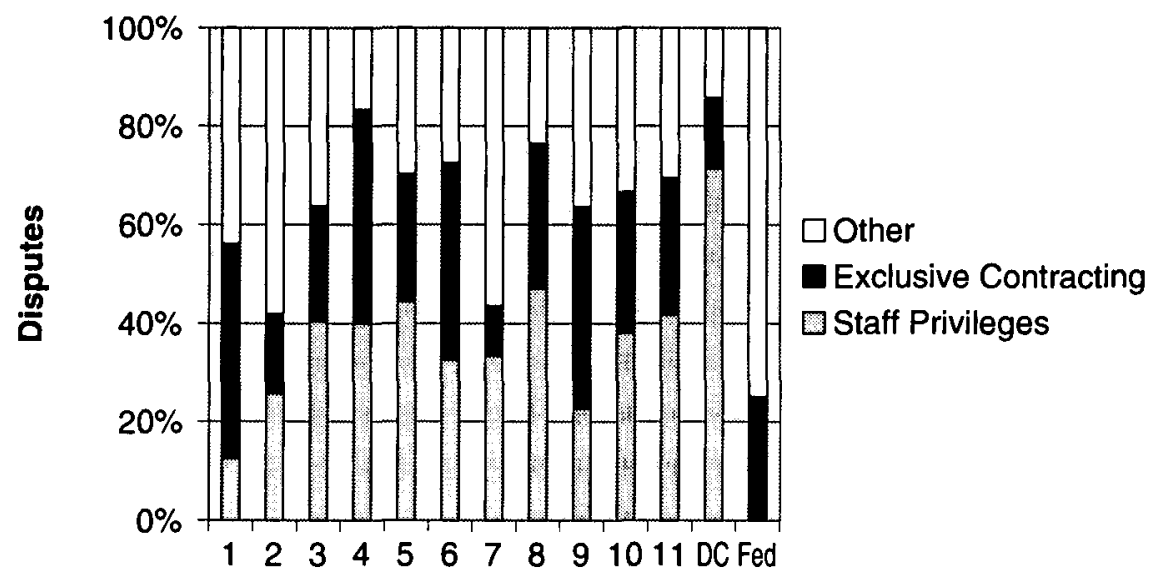

Federal Judicial Circuit

5. Procedural Posture and Outcome. - Motions heard by federal district judges accounted for $331(65 \%)$ of the 511 private opinions in our database, most of which (286) were defense motions for summary judgment, with the remainder including motions by plaintiffs for injunctive relief, post-trial motions, motions in limine to exclude evidence, and fights over the scope of discovery. The remaining 178 opinions (35\%) 
were written by appellate courts, over $80 \%$ of those ( 145 opinions) resolving appeals by plaintiffs. These results imply that defendants in health care antitrust cases usually succeed in deflecting suits prior to trial. ${ }^{70}$

The infrequency with which plaintiffs prevail in private health care antitrust disputes is confirmed by our results regarding significant dispositions in favor of one party or the other. We considered a disposition to be "significant" if it determined or substantially influenced the overall outcome of the dispute between the parties. Minor procedural rulings in favor of one party were not considered significant. We counted denial of a summary judgment motion made by the defendant as a plaintiff victory, because it imposes potentially large trial costs on defendants even if they eventually prevail, and therefore promotes settlement. ${ }^{71} \mathrm{We}$ also counted a significant outcome for the plaintiff in a given opinion as a plaintiff victory regardless of whether it was subsequently reversed on appeal. ${ }^{72}$ Even with this expansive definition of plaintiff victory, only 70 (14\%) of the opinions in our database favored plaintiffs, while $341(67 \%)$ favored defendants and $100(20 \%)$ did not significantly benefit either party.

Separating opinions according to business conduct (see Figure 6), plaintiffs were least successful in staff privileges cases, prevailing in only 12 opinions $(7 \%) .{ }^{73}$ Plaintiffs were most successful in cases involving information, prevailing on 11 occasions (26\%). Exclusive contracting cases, insurance cases, and "other" cases (for example, pharmaceutical disputes) showed intermediate rates of plaintiff victories.

Several other attributes of private cases were significantly correlated with the disposition of judicial opinions, some of which were likely mediated by the business conduct at issue. Physician plaintiffs were less likely to obtain favorable rulings than other types of plaintiffs such as hospitals, insurance related organizations, or pharmaceutical companies. Insurance or pharmaceutical company defendants were less likely to obtain favorable rulings than physician or hospital defendants. Opinions from

70. As noted previously, a limitation of our study is that we cannot determine the percentage of cases that settle or the terms of such settlements. See supra text accompanying notes 45-46. For example, it is possible that denials of medical staff privileges are revisited when legal complaints are filed, and membership subsequently granted. Our sense based on experience, however, is that these suits are more likely to be dropped by plaintiffs than to be settled by defendants.

71. In the process of briefing and arguing the defendant's unsuccessful summary judgment motion, the parties also obtain additional information about the merits of their rival's case, as well as the judge's disposition toward the underlying claim. The reduction in uncertainty created by the new information may lead the parties' expectations to come closer together, which may induce settlement.

72. Again, this approach differs from traditional forms of legal analysis that focus primarily upon the outcome at the final stage of the legal process. As made clear in our discussion of methodology, judicial opinions are being viewed as social science data, not precedent, and as discrete social artifacts, not sources of law.

73. Plaintiffs were also unsuccessful in challenging corporate combinations, although the number of cases in this category was too low to draw conclusions with confidence. 
Figure 6: Effect of Business Conduct on Disposition of Private Litigation

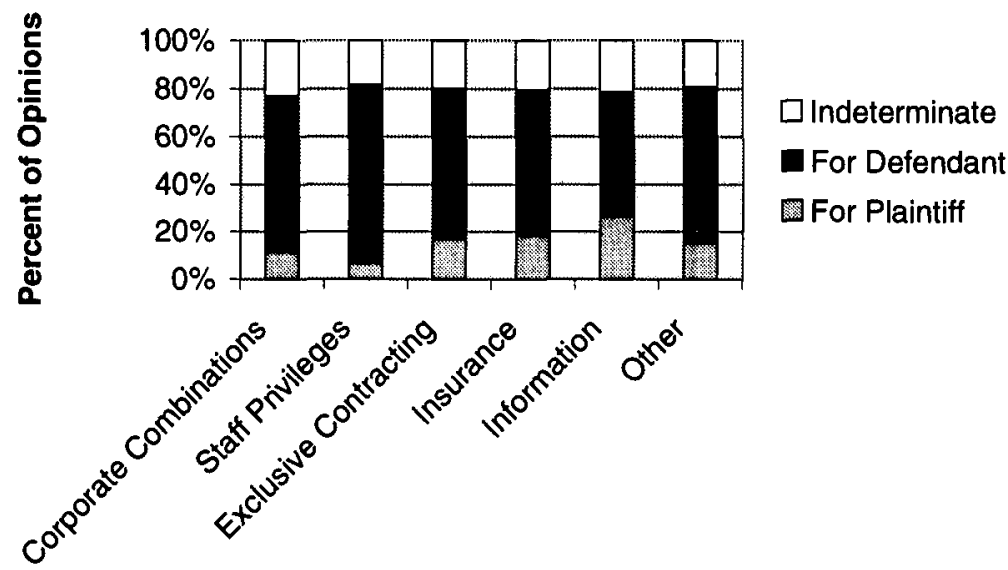

courts in the Tenth, Fourth, and Second Circuits were more likely to find for plaintiffs than courts in the First, Eleventh, or Sixth Circuits. ${ }^{74}$ The findings regarding the Fourth and First Circuits are surprising because the former heard a comparatively large percentage of staff privileges and exclusive contracting claims, which are hard to win, while the latter heard relatively few of those cases.

Interestingly, the size of geographic market did not correlate with outcome. Nor did the five-year period during which an opinion was issued influence its disposition, except that opinions issued in 1990-I994 were more likely to be indeterminate than to favor defendants, while opinions issued in 1995-I999 were more likely to favor defendants than to be indeterminate (the proportion favoring plaintiffs remained constant). This difference was primarily attributable to staff privileges cases, raising the possibility that the courts required a few years to develop confidence applying the Health Care Quality Improvement Act of 1986.

Only 14 disputes (4\%; generating 22 opinions) resulted in courts granting remedies to private plaintiffs. Damages were awarded in just 6 disputes (generating 10 opinions). ${ }^{75}$ Injunctions were granted in just 3

74. A caveat is that the absolute number of cases in some of these jurisdictions was small, making these findings unstable despite their statistical significance.

75. Brown v. Presbyterian Healthcare Servs., 101 F.3d 1324, 1336 (10th Cir. 1996) (reversing district court's order vacating jury's award of compensatory and punitive damages on plaintiff's tortious interference claim; affirming denial of punitive damages on antitrust claim and affirming jury's finding of antitrust liability and damages); Oltz v. St. Peter's Cmty. Hosp., 656 F. Supp. 760, 765 (D. Mont. 1987) (upholding jury verdict in favor of plaintiff nurse anesthetist on antitrust liability, but granting defendant's motion for new trial on damages), aff'd, 861 F.2d 1440, 1452-53 (9th Cir. 1988) (affirming district court's finding of liability and holding that ordering new trial on damages was not abuse of discretion), remand to No. CV 81-271-H-JFB, 1991 U.S. Dist. LEXIS 20594, *24 (D. Mont. May 10, 1991) (excluding certain of plaintiff's proffered evidence on damages and 
disputes (generating 6 opinions). ${ }^{76}$ Two of the disputes resulting in damage awards were staff privileges cases, two were exclusive contracting cases, and two were insurance cases (including one involving allegations of a boycott and exclusionary conduct to block the market entry of an HMO). Other remedies included a successful effort to remove an antitrust case out of a bankruptcy court, and a defendant successfully obtaining Rule 11 sanctions against a plaintiff bringing a frivolous antitrust claim. ${ }^{77}$ As discussed below, the DOJ and FTC have had substantially greater success than private plaintiffs, but even their remedies have been

granting defendant's motion for partial summary judgment), rev'd, 19 F.3d 1312, 1313 (9th Cir. 1994) (reversing partial summary judgment on damages and remanding for a new trial); Reazin v. Blue Cross \& Blue Shield of Kan., Inc., 663 F. Supp. 1360, 1421, 1429-30 (D. Kan. 1987) (upholding jury verdict on Sherman Act $\$ 1$ and $\$ 2$ claims, state tortious interference claim, and award of damages), aff'd, 899 F.2d 951, 983 (10th Cir. 1990).

76. Redwood Empire Life Support v. County of Sonoma, No. 91-16444, 1993 U.S. App. LEXIS 1913, at *2 (9th Cir. Jan. 29, 1993) (affirming grant of preliminary injunction to antitrust plaintiff as not being abuse of district court's discretion); Blue Cross \& Blue Shield United of Wis. v. Marshfield Clinic, 883 F. Supp. 1247, 1258-60, 1267 (W.D. Wis. 1995) (upholding jury's Sherman Act $\S 1$ and $\S 2$ verdicts and entering broad injunctive relief in the form of a conduct remedy), aff'd in part and rev'd in part, 65 F.3d 1406, 1411-17 (7th Cir. 1995) (reversing finding of liability on price fixing and monopolization claims, but affirming finding of liability on market allocation claim and remanding case for new trial on damages resulting from illegal market allocation agreement and to reformulate injunction), remanded by 980 F. Supp. 1298, 1301-02 (W.D. Wis. 1997) (district court granting defendant's motion for partial summary judgment holding that plaintiff failed to prove damages on market allocation claim and dissolving completely its previous injunction), aff' $d$ in part and vacated in part, 152 F.3d 588 (7th Cir. 1998) (affirming grant of summary judgment due to absence of damages, but reversing on question of plaintiff's entitlement to injunctive relief and some portion of fees and costs); Wilk v. Am. Med. Assoc., 671 F. Supp. 1465, 1477-84, 1505 (N.D. 11l. 1987) (finding on remand that AMA was liable for antitrust violations against plaintiff chiropractor and issuing permanent injunction against specific illegal conduct), aff d, 895 F.2d 352, 355 (7th Cir. 1990); see also FTC v. Univ. Health, Inc., 938 F.2d 1206, 1225-26 (11th Cir. 1991) (reversing district court's denial of FTC's request for preliminary injunction and issuing its own injunction to block defendant hospital merger pending FTC adjudication); FTC v. Tenet Healthcare Corp., 17 F. Supp. 2d 937, 939 (E.D. Mo. 1998) (issuing preliminary injunction enjoining hospital merger pending full administrative review), rev'd, 186 F.3d 1045, 1055 (8th Cir. 1999); FTC v. Cardinal Health, 1nc., 12 F. Supp. 2d 34, 68 (D.D.C. 1998) (granting FTC preliminary injunction preventing merger of wholesale prescription drug distributors); United States v. Rockford Mem'l Corp., 717 F. Supp. 1251, 1292 (N.D. Ill. 1989) (granting DOJ's motion for preliminary injunction preventing hospital merger), aff d, 898 F.2d 1278, 1286 (7th Cir. 1990).

77. See Lifemark Hosps. of La. v. Liljeberg Enters., Inc., 161 B.R. 21, 27 (Bankr. E.D. La. 1993) (granting plaintiff's motion to remove antitrust issue from bankruptcy proceeding); Colo. Chiropractic Council v. Porter Mem'l Hosp., 650 F. Supp. 231, 245 (D. Col. 1986) (ordering Rule 11 sanctions against losing antitnust plaintiff for bringing frivolous suit); see also United States v. N.D. Hosp. Ass'n, 640 F. Supp. 1028, 1044 (D.N.D. 1986) (granting DOJ's summary judgment motion on liability, but denying government's request for injunction because there was no continuing violation). 
limited. ${ }^{78}$ For example, only one case in our sample involved criminal penalties. ${ }^{79}$

6. Antitrust Allegations and Violations. - The range of antitrust violations in the cases we examined can be divided into three categories: allegations under the Sherman or Clayton Act traditionally considered "per se" violations of law (for example, price fixing), allegations under the Sherman or Clayton Act usually subjected to more detailed rule-of-reason analysis (for example, exclusive dealing), and allegations under other statutes such as the Robinson-Patman Act or various state antitrust laws. Most antitrust plaintiffs will allege as many violations as possible in their complaints. For example, alleging conduct that is illegal per se is strategically valuable because it can reduce plaintiffs' discovery and expert witness costs (anticompetitive effects are presumed once a prima facie case is established). We coded alleged violations only when the court rendering the opinion took the issue seriously enough to discuss its merits.

The most common allegations were unreasonable restraint of trade (184 opinions; $36 \%$ ), monopolization (184 opinions; $36 \%$ ), attempted monopolization (156 opinions; $31 \%$ ), and boycott (146 opinions; $29 \%$ ). These allegations correspond to the fact patterns presented in staff privileges and exclusive contracting cases. Violations that would fall into traditional per se illegal categories of antitrust law were alleged 237 times in the 511 private opinions reviewed. Because of the prevalence of staff privileges disputes, more than half (146) were boycott claims. Boycott claims are useful because they may trigger a form of per se liability, although the pragmatic benefits of claiming per se illegal boycotts are less significant after cases such as Northwest Wholesale Stationers, Inc. v. Pacific Stationary E Printing Co. ${ }^{80}$

Hard core per se violations-price fixing, geographic market allocation, and product market allocation-were alleged in a total of 63 opinions $(12 \%)$. These allegations were raised more often in insurance cases (24 opinions; $27 \%$ ) exclusive contracting cases (18 opinions; $13 \%$ ), and

78. See infra text accompanying notes $98-104$.

79. United States v. Alston, 974 F.2d 1206, 1215 (9th Cir. 1992) (reversing acquittals notwithstanding verdict against two dentists for illegal price fixing, but permitting district court to consider ordering new trials). The absence of criminal prosecutions stands in contrast with the Reagan and early Bush administrations' policies in other areas of antitrust enforcement, which orchestrated a shift away from civil and towards criminal cases. See GAO Report, supra note 17, at 3 (noting shift).

80. 472 U.S. 284, 298 (1985) (holding that conduct of joint purchasing cooperative was not per se unlawful absent proof of market power). While the state of boycott law remains confused after Northwest Wholesale Stationers, most courts require proof of some level of market power on the part of the defendant before invoking the per se rule. A similar "soft" per se rule now governs tying agreements as well. See Jefferson Parish Hosp. Dist. No. 2 v. Hyde, 466 U.S. 2, 15-16 (1984) (adding market power requirement as part of plaintiff's prima facie case before invoking per se rule against tying). But see NYNEX Corp. v. Discon, Inc., 525 U.S. 128, 135 (1998), and FTC v. Superior Court Trial Lawyers Ass'n, 493 U.S. 4I1, 421-23 (1990), for cases suggesting that some aspects of a hard per se rule may still exist for certain group boycotts. 
"other" business conduct cases (11 opinion; $14 \%$ ) than in information cases ( 4 opinions; $10 \%$ ), staff privileges cases ( 8 opinions; $4 \%$ ), and corporate combination cases ( 1 opinion; $3 \%$ ). Illegal tying was alleged in 63 opinions $(12 \%)$.

As might be expected from the low number of pro-plaintiff outcomes detailed above, few actual violations of antitrust law were ascribed by federal courts in written judicial opinions. ${ }^{81}$ Potentially per se illegal conduct (including boycotts) was identified in only 10 different opinions. Price fixing violations were found in 2 opinions representing two separate disputes. ${ }^{82}$ Per se illegal geographic market allocations were found in 4 opinions from the same underlying dispute, one of which also opined that product markets had been unlawfully allocated. ${ }^{83}$ Concerted refusals to deal or group boycotts were found in 3 opinions representing three disputes. ${ }^{84}$ Allegations not suggesting per se illegality generated a total of I4 opinions finding actual violations of antitrust law. Six opinions representing four disputes found violations best classified as "unreasonable restraints of trade" under section 1 of the Sherman Act, although these cases generally have undercurrents of price fixing and boycotts as well. ${ }^{85}$

81. Recall that in our coding system we treat each opinion as a separate unit, and, therefore, include violations found at the district court level that were subsequently reversed on appeal, as well as violations in opinions that form only part of an overall dispute.

82. See Blue Cross \& Blue Shield United of Wis. v. Marshfield Clinic, 883 F. Supp. 1247,1259 (W.D. Wis. 1995), rev'd in part and aff'd in part, 65 F.3d 1406, 1417 (7th Cir. 1995); Hahn v. Or. Physicians' Serv., No. 78-0887-MA, 1990 U.S. Dist. LEX1S 16899, *11-*12 (D. Or. Oct. 26, 1990). The court in Sandy River Nursing Care v. Aetna Cas., 985 F.2d 1138, 1147-48 (1st Cir. 1993), expressly found a per se illegal price fixing agreement, but concluded that the conduct was immunized under the state action doctrine.

83. See Marshfield Clinic, 883 F. Supp. at 1259, aff'd, 65 F.3d 1406 (7th Cir. 1995).

84. See Patrick v. Burget, 486 U.S. 94, 105-06 (1988) (finding no state action immunity and reinstating jury verdict of concerted refusal to deal); Hahn, 1990 U.S. Dist. LEXIS 16899, at $* 11-12$ (finding that physician boycott of podiatrists had effect of unreasonably restricting trade); Wilk v. Am. Med. Ass'n, 671 F. Supp. 1465, 1477 (E.D. Ill. 1987) (finding AMA liable for concerted refusal to deal), aff'd, 895 F.2d 352, 378 (7th Cir. 1990). Again, the court in Sandy River Nursing Care, 985 F.2d at 1147-48, found behavior constituting a group boycott, but held such conduct immune.

85. See Boczar v. Manatee Hosps. \& Health Sys., Inc., 993 F.2d 1514, 1519 (11th Cir. 1993) (reversing district court JNOV and reinstating a jury verdict finding an unreasonable restraint of trade); Key Enters. of Del., Inc. v. Venice Hosp., 919 F.2d 1550, 1560-62 (11th Cir. 1990) (reinstating jury verdict for plaintiff in durable medical equipment case finding reciprocal dealing), reh'g en banc granted, 979 F.2d 806 (11 th Cir. 1992); Oltz v. St. Peter's Cmty. Hosp., 656 F. Supp. 760, 763 (D. Mont. 1987) (upholding jury verdict finding unreasonable restraint of trade), aff'd, 861 F.2d 1440 (9th Cir. 1988); Reazin v. Blue Cross \& Blue Shield of Kan., Inc., 663 F. Supp. 1360, 1425 (D. Kan. 1987) (upholding jury finding of an unreasonable restraint of trade), aff'd, 899 F.2d 951 (10th Cir. 1990); see also United States v. N.D. Hosp. Ass'n, 640 F. Supp. 1028, 1036-41 (D.N.D. 1986) (granting DOJ motion for summary judgment finding Sherman Act section 1 violation). In some of these cases, one gets the impression that courts make a conscious effort not to frame the claim as a boycott in order to avoid addressing a complicated and confusing area of law. 
Three opinions, representing two disputes, found section 2 monopolization violations. ${ }^{86}$

It is interesting that price fixing and tying arrangements were alleged more often in the Georgetown Antitrust Project, which surveyed general antitrust litigation, than in our sample of health care cases. ${ }^{87}$ Fewer price fixing allegations in health care may reflect the deterrent effect of high profile public enforcement actions in the medical industry, as well as the influence of the Supreme Court's 1982 decision in Maricopa confirming the appropriateness of per se liability for medical professionals. ${ }^{88}$ It may also reflect the intrinsic difficulties in concealing price fixing agreements between health care providers for very long in a system predicated upon third party payment. Similarly, the Supreme Court's 1984 decision in Jefferson Parish Hospital District No. 2 v. Hyde rejecting tying liability for the hospital's exclusive contract may have had a chilling effect on such claims in the health care sector during our sample period. ${ }^{89}$

The Georgetown Antitrust Project and NERA also both reported high numbers of boycotts, concerted refusals to deal, and dealer termination cases, although the groupings and understandings of these claims

86. See Marshfield Clinic, 883 F. Supp. at 1255-59, 1265, rev'd in part and aff'd in part, 65 F.3d 1406 (7th Cir. 1995); Reazin, 663 F. Supp. at 1486-89 (upholding jury verdict on section 2 monopolization claim), aff'd, 899 F.2d 951 (10th Cir. 1990).

87. According to the Georgetown Antitrust Project, traditional categories of per se illegality dominate other antitrust allegations. Horizontal price fixing was alleged in $21.3 \%$ of all cases, refusals to deal in $25.4 \%$ of cases, and tying or exclusive dealing in $21.1 \%$ of cases (reporting results combining primary and secondary allegations). Salop \& White, supra note 15 , at 6 . The authors allowed as many codes as were relevant to be marked, so that (as with many of our results) percentages usually do not sum to 100 . Differences in methodology may account for this disparity. The Georgetown Antitrust Project and NERA report allegations made in the complaint. Our methodology was to count only allegations substantively addressed by courts in their opinions.

88. Arizona v. Maricopa County Med. Soc'y, 457 U.S. 332, 335-37, 357 (1982). On the other hand, this result appears to be fairly sensitive to the manner in which the coding takes place. For example, if one uses the NERA study to calculate alleged violations as a percentage of the number of cases, horizontal price fixing and market allocations were alleged in only $11.2 \%$ of all cases-roughly comparable to our finding of price fixing being a seriously addressed violation in approximately $9 \%$ of the cases. See NERA, Antitrust Report, supra note 16, at 28 (calculation based on Table 8). One must also consider the extent to which differences reflect disparities in the time frames: 1973-1978 (NERA), 1973-1983 (Georgetown), and 1985-1999 (our sample). One should consider as well differences in geographic location. All the NERA data comes from the Southern District of New York (Manhattan), where one might expect garden variety price fixing to constitute a lower percentage of the antitrust disputes than would be found elsewhere. For a brief summary of the methodologies employed in these studies, see supra notes 15-18.

89. 466 U.S. 2, 28-29 (1984). Again, however, the lower number of tying allegations in our sample reflects in part different groupings in the respective coding instruments. Rather than grouping exclusive dealing cases with tying cases, we coded exclusive dealing under the category of vertical nonprice restraints and coded tying cases separately. NERA grouped tying cases with exclusive dealing cases and reported that, as a percentage of cases rather than allegations, they arose in a surprising $43.9 \%$ of all disputes. See NERA, Antitrust Report, supra note 16, at 28 (calculation based on Table 8). 
are likely to differ to some degree from ours. ${ }^{90}$ These statistics suggest that boycott and dealer termination claims in antitrust law generally may play an analogous role to that of staff privileges cases in health care; i.e., plaintiffs often complaining about the intensity of competition rather than its absence. Interestingly, allegations of unspecified restraints of trade in violation of section 1 of the Sherman Act and allegations of monopolization and attempted monopolization in violation of section 2 were less common in private antitrust litigation generally than in our health care sample. ${ }^{91}$ The greater role of monopolization and attempted monopolization in our sample reflects, in part, the disproportionate presence of hospitals as defendants. To challenge the unitary acts of a hospital in either a staff privileges or exclusive contracting case, the complaint must often be styled in terms of either monopolization or attempted monopolization. ${ }^{92}$ The greater role of monopolization and attempted monopolization claims also reflects the higher levels of concentration characteristic of service markets.

7. Antitrust Analysis. - Befitting the predominance of cases that require plaintiffs to prove that defendants possess market power ("rule of reason" cases under section 1 of the Sherman Act, all claims under section 2 of the Sherman Act, and merger cases), 176 opinions in private antitrust disputes (34\%) discussed market definition, and 144 opinions $(28 \%)$ discussed levels of market concentration. The fact that only 49 opinions $(10 \%)$ evaluated barriers to market entry by new competitors suggests that courts were able to shortcut their analysis in a substantial number of cases after holding that the market was not sufficiently concentrated to support a finding of market power.

Defenses are extremely common in health care antitrust litigation, existing in one form or another in almost all opinions. ${ }^{93}$ By far the most

90. Georgetown's combined total was $34.3 \%$. See Salop \& White, supra note 15 , at 6 (calculations based on Table 1.4). NERA's adjusted combined total was $45.6 \%$. See NERA, Antitrust Report, supra note 16, at 28 (calculation based on Table 8).

91. The Georgetown study found allegations of generic "restraints of trade" in only $10 \%$ of the complaints and allegations of monopoly or attempted monopolization in only $8.8 \%$ of complaints. See Salop \& White, supra note 15 , at 6 . The NERA study did not even break out monopolization concerns as an independent line on its tables.

92. Section 1 allegations typically run up against the Copperweld doctrine when a hospital is accused of conspiring with its own medical staff. See, e.g., Oksanen v. Page Mem'l Hosp., 945 F.2d 696, 703-04 (4th Cir. 1991) (holding no Sherman Act section 1 claim can be based upon the plaintiff's revocation of staff privileges because under Copperweld a hospital cannot conspire with itself); Canady v. Providence Hosp., 903 F. Supp. 125, 127 (D.D.C. 1995) (granting defendants' motion to dismiss by finding no concerted action in light of the Copperweld doctrine); Purgess v. Sharrock, 806 F. Supp. 1102,1109 (S.D.N.Y. 1992) (identifying circuits in which hospitals have been found to be incapable of conspiring with members of their medical staffs).

93. We use the term "defenses" very loosely. These "defenses" encompass a broad range of considerations, not all of which fit tightly into understandings of affirmative defenses or claims of immunity. Defenses here are intended to capture the wide range of arguments defendants might employ in avoiding antitrust liability. 
common defenses were lack of standing to sue or the absence of antitrust injury, which are related doctrines (243 opinions; $48 \%$ ). Defenses involving legitimate business purposes, procompetitive effects, and efficiencies were raised in 110 separate opinions (22\%). Other commonly discussed defenses included state action (Parker) immunity (88 opinions; 17\%), lack of a conspiracy because only one enterprise was involved (Copperweld) (77 opinions; $15 \%$ ), peer review immunity under HCQIA (44 opinions; $8 \%$ ), and political action (Noerr-Pennington) immunity (40 opinions; $8 \%$ ).

Looking at judicial analysis by time period, discussions of market definition, market concentration, and entry barrier analysis were less frequent in 1985-1989 than in recent periods when merger cases have become more common. Essential facility claims arose most often in 1990-1995, tracking the expansion of managed care into markets dominated by a single hospital or medical group. Oligopoly explicitly entered courts' discussions only in 1995-1999. Defenses based on intraenterprise conspiracy were less common in 1985-1989 than subsequently, but state action and McCarran-Ferguson Act $^{94}$ defenses were more common earlier. Finally, per se analysis was performed less frequently by courts in 1985-1989 than in more recent periods. Although this undoubtedly reflects the changing case mix over time, it may also indicate lower courts' growing comfort with the Supreme Court's 1982 refusal in Maricopa to immunize professional activities from per se scrutiny. ${ }^{95}$

Legal analysis correlated strongly with the type of parties involved and the business conduct at issue. Regardless of whether hospitals, physicians, insurance organizations, pharmaceutical companies, or other parties were plaintiffs or defendants, courts assessed market definition and concentration more or less equally across the board. Evaluation of barriers to entry, by contrast, was emphasized in cases with insurance plaintiffs or defendants, with courts generally holding that such barrier are low in insurance markets. Cases with physician plaintiffs and defendants indulged in fewer discussions of entry barriers, likely because claims were disposed of before reaching that point in the analysis of market power. Correspondingly, examining the case according to business conduct reveals that entry barrier analysis is concentrated in corporate combination cases (for example, mergers) and insurance cases, and is conspicuously absent from staff privileges disputes. Interestingly, courts defined markets most often in exclusive contracting cases, generally in order to determine whether the defendant possessed sufficient power to render

94. 15 U.S.C. § 1011 (1994).

95. 1t will be interesting to see if this pattern reverses course in the future as lower courts digest the Supreme Court's revival in California Dental of Goldfarb's dictum regarding professional activities and rule of reason analysis. See Cal. Dental Ass'n v. FTC, 526 U.S. 756, 771 n.10 (1999) (quoting Goldfarb v. Va. State Bar, 421 U.S. 773,788 n.17 (1975) (suggesting that the public service aspects of the professions might justify special antitrust treatment)). 
an exclusive arrangement anticompetitive. The fact that exclusive contracting cases defined markets much more frequently than staff privileges cases supports the inference that courts view these categories as analytically distinct rather than merely excusing all hospital defendants from antitrust scrutiny.

Lack of antitrust injury or standing was the most common defense analyzed in suits against hospitals and insurance companies as defendants, and was also invoked frequently by other types of defendants. Pharmaceutical companies most often invoked an efficiencies defense; that approach was also common in cases with insurers as defendants. HCQLA predictably was the principal defense for physicians, and applied uniquely to them (much as McCarran-Ferguson Act defenses are available only to insurance companies). State action immunity was employed liberally by physician and hospital defendants, but not by insurance or pharmaceutical companies. Political action immunity was much more commonly discussed in suits against pharmaceutical companies than in other cases. Sorting according to categories of business conduct, efficiencies defenses were least common in staff privileges cases (again distinguishing those cases from exclusive contracting disputes). Discussions of state action immunity were clustered in staff privileges and exclusive contracting cases, and political action immunity was addressed mainly in the residual category of cases that includes pharmaceutical and other medical product litigation. As expected, HCQIA was strictly limited to staff privileges disputes.

The prevalence and diversity of these defenses illustrate several facets of contemporary antitrust law. Courts' reliance upon structural economic analysis and the screening role played by the antitrust injury doctrine are striking. To prevail on an antitrust claim, the plaintiff must establish an injury to competition. This typically requires the defendant to be large enough to possess some level of market power and the conduct in question to be substantial enough to have an adverse impact on the market. If these conditions are not satisfied, then the case can be dismissed at a relatively early stage of the proceedings. Our data suggest that this is happening in a large number of medical antitrust cases and that staff privileges and exclusive contracting cases are particularly vulnerable to this type of attack.

Other defenses serve quite different functions. Unlike screening devices, consideration of economic efficiencies, procompetitive benefits, and the presence of legitimate business justifications are indicative of merits-based analysis likely to be associated with closer and more difficult cases. The fact that this type of analysis takes place on a substantially less frequent basis as compared with analysis of antitrust injury suggests that cases where an actual assessment of the merits is necessary are the exception, not the rule.

A final category of defenses includes various types of statutory antitrust immunity. The immunity enjoyed by certain labor, insurance, and 
physician peer review practices represents a type of legal zoning, in which Congress has declared certain conduct to be antitrust concerns and other conduct not. These defenses also perform an implicit channeling function, taking classes of disputes out of the judicial arena and forcing battles over the nature of antitrust liability to be fought in the legislature. The judicially crafted state action doctrine and, to a lesser extent, the Noerr-Pennington doctrine serve similar functions. Not surprisingly considering the strong regulatory tradition in health care, defenses serving these zoning and channeling functions play a significant role in health care antitrust litigation.

A few other correlations are worth noting. Some differences in legal analysis over time were observed in the data. Invocation of state action immunity declined from 1985-1989 to 1995-1999, while use of the Copperweld doctrine increased. Although HCQIA was enacted in 1986, its effect only became apparent in litigation after 1990. On the other hand, size of geographic market did not correlate with market power analysis, and only influenced analysis of legal defenses to the extent that medical products cases involve large geographic markets. The number of cases within each federal judicial circuit was too small to support strong statistical claims, but a curious finding was that cases in the Tenth Circuit analyzed barriers to entry much more often than cases elsewhere, while cases in the Eighth Circuit hardly discussed barriers to entry at all.

Finally, monopsony was considered in only two opinions. ${ }^{96}$ Considering that managed care has led to the proliferation of intermediary organizations that purchase health care services from providers and resell them to end users under various insurance arrangements, it is striking that concentrated purchasing power is so rarely attacked directly in antitrust litigation. ${ }^{97}$ Rather than seeing the concerted action of purchasers

96. The two opinions coded for discussing monopsony power were U.S. Healthcare, Inc. v. Healthsource, Inc., 986 F.2d 589, 598 (1st Cir. 1993), and Ball Mem'l Hosp., 1nc. v. Mutual Hosp. Ins., 1nc., 784 F.2d 1325, 1334 (7th Cir. 1986). In U.S. Healthcare, the First Circuit rejected the argument that the defendant HMO possessed monopsony power in large part because it rejected the existence of a distinct market for HMO services as opposed to a market for health care services and financing more generally. $986 \mathrm{~F} .2 \mathrm{~d}$ at 598. Similarly, in Ball Memorial, the Seventh Circuit affirmed the denial of a requested preliminary injunction seeking to prevent the plaintiff from offering a new preferred provider organization (PPO) product. $784 \mathrm{~F} .2 \mathrm{~d}$ at 1346 . Defining the market broadly to include all health care services and financing, the court held the plaintiff lacked market power and therefore there could be no Sherman Act section 1 or section 2 violation. Id. at 1337.

97. One explanation is that antitrust law has always been relatively more tolerant of buyer than of seller behavior. See Kartell v. Blue Shield, 749 F.2d 922, 930 (1st Cir. 1984) (praising the aggressive actions of the health care insurer for producing low prices for its subscribers). Part of the greater deference afforded buyers may result from the analytic difficulty courts have understanding that the problems of monopsony power are symmetric to the problems of monopoly power. See Hovenkamp, supra note $3, \S 1.2 \mathrm{~b}$ (outlining the economic consequences of monopsony power). Another part may represent legitimate recognition by courts that joint activity on the buyer side of the market can reduce the transaction costs of purchasing in procompetitive ways. See, e.g., Northwest Wholesale 
as an antitrust problem, however, courts in 14 opinions (3\%) considered the defense that the conduct in question was by a buyer rather than a seller and therefore should be treated more favorably.

\section{B. Public Antitrust Enforcement}

Of the 542 opinions in our sample, only 31 (representing 22 disputes) involved cases brought by the DOJ (10 disputes), the FTC (11 disputes), or state attorneys general ( 1 dispute). In addition, 52 administrative decisions and consent orders with private parties were entered by the FTC during the period of our sample in 39 disputes, as were 22 consent decrees between private parties and the DOJ ( 3 of them also involving states) in 20 disputes, and 8 consent decrees between private parties and state attorneys general. Public litigation remained uncommon from the first five-year period studied to the most recent. By contrast, consent decrees and administrative actions by the DOJ and the FTC rose sharply in later years of the study (see Figure 7).

Figure 7: Public Enforcement 1985-99

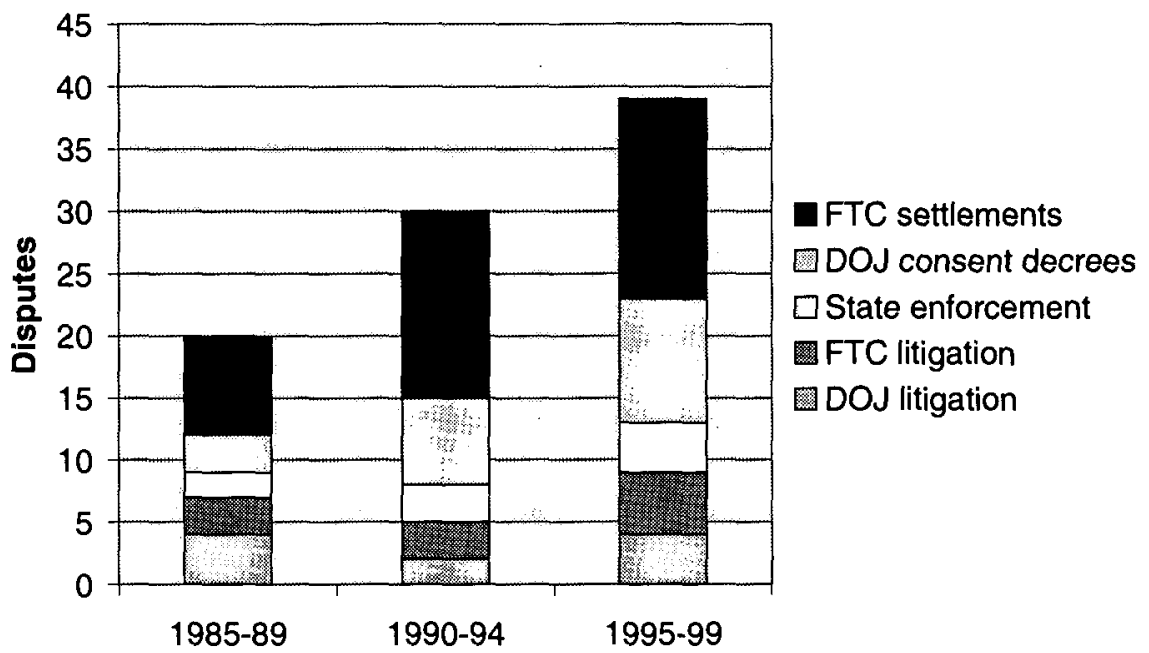

Stationers, Inc. v. Pac. Stationery \& Printing Co., 472 U.S. 284, 295 (1985) (discussing efficiencies of joint purchasing). Another set of explanations concerns whether and when market power will exist on the buyer's side of health care markets. As acknowledged in U.S. Healthcare and Ball Memorial, the markets for health care financing in which these purchasers act as resellers are so large, both geographically and in product scope, that a formal finding of market power is unlikely. See U.S. Healthcare, 986 F.2d at 598; Ball Memorial, 784 F.2d at 1334-35; see also Blue Cross \& Blue Shield United of Wis. v. Marshfield Clinic, 65 F.3d 1406, 1413 (7th Cir. 1995) (rejecting the idea of a distinct HMO market). Still, monopsony continues to generate academic interest. See, e.g., Mark V. Pauly, Market Power, Monopsony, and Health Insurance Markets, $7 \mathrm{~J}$. Health Econ. 111, 111 (1988); Mark V. Pauly, Monopsony Power in Health Insurance: Thinking Straight While Standing on Your Head, 6 J. Health Econ. 73, 74 (1987). 
Government plaintiffs were much more successful in court, carrying $42 \%$ of opinions that reached a significant disposition, than were private plaintiffs, who carried $14 \%$ (see Figure 8 ). More than half of the government cases $(18 ; 58 \%)$ involved allegedly anticompetitive mergers. Only one case found an actual Clayton Act section 7 merger violation, although courts in another 4 disputes granted the government preliminary injunctions in merger cases. ${ }^{98}$ The remainder of the allegations split nearly equally among boycotts, monopolization, and unreasonable restraints of trade. Two opinions in different disputes found violations of section 5 of the FTC Act, based on unreasonable restraints of trade. ${ }^{99}$ Only one fully litigated case each alleged price fixing, product market allocation, or geographic market allocation, presumably because parties caught in these acts tend to settle the charges against them rather than go to court.

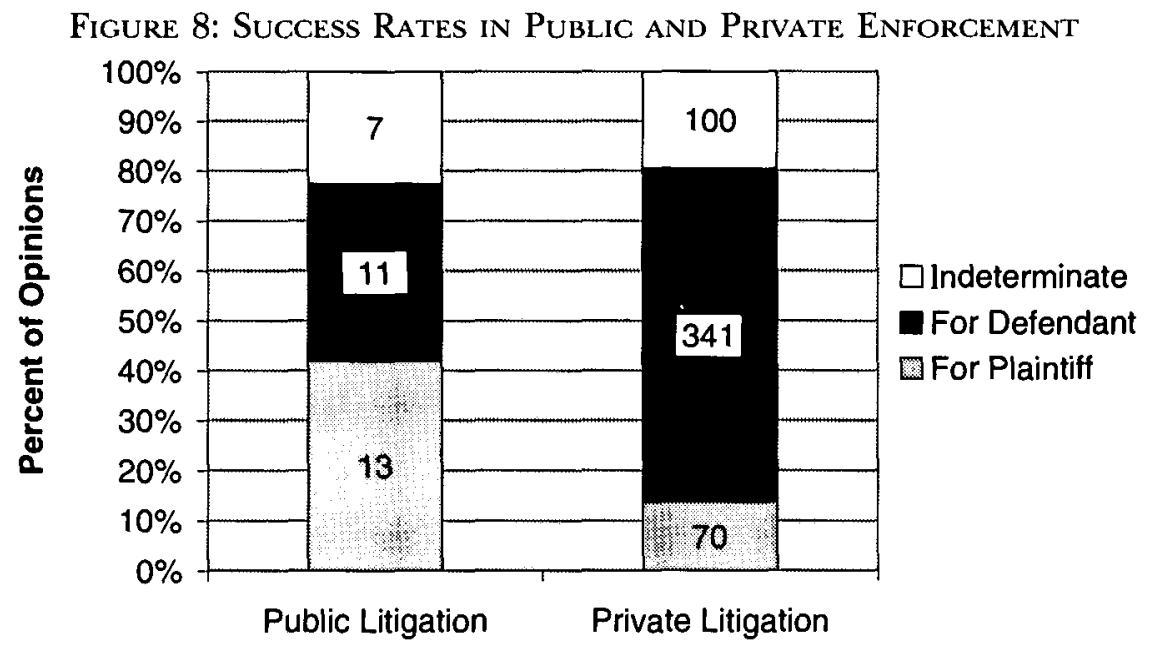

In 50 of the 82 settled cases in our sample $(61 \%)$, enforcement action resulted in injunctive relief in favor of the DOJ or state attorneys general, or the issuance of a cease and desist order by the FTC. The FTC also required full or partial divestiture in 18 merger settlements $(21 \%)$ and compulsory licensing in 4 settlements $(5 \%)$. Damages were sought as

98. See Hosp. Corp. of Am. v. FTC, 807 F.2d 1381, 1389 (7th Cir. 1986) (upholding FTC determination that merger violated the Clayton Act). Given changes in the law which permit the FTC to seek preliminary injunctions against mergers in district court, most cases are now won or lost at the injunction stage. Disputes resulting in successful injunctive relief are detailed supra note 76 .

99. See FTC v. Ind. Fed'n of Dentists, 476 U.S. 447, 466 (1986) (finding refusal to supply $x$-rays violated section 1 of the Sherman Act and therefore constituted a violation of section 5 of the FTC Act); Cal. Dental Ass'n v. FTC, 128 F.3d 720, 730 (9th Cir. 1997) (upholding FTC finding of an unfair trade practice), rev'd, 526 U.S. 756 (1999), on remand, 224 F.3d 942 (9th Cir. 2000) (finding insufficient evidence to establish a violation under the rule of reason). 
part of the settlement of only two consent decrees, both of which were brought by state attorneys general. In a handful of instances, defendants subsequently prevailed before the FTC in efforts to modify or set aside consent orders.

Combining litigated cases with consent decrees and settlements provides an overall picture of public enforcement that differs from private litigation in several respects. Public enforcement was more likely than private litigation to involve pharmaceutical companies $(20 \%$ vs. $12 \%$ of disputes) and professional or trade associations (15\% vs. $6 \%)$ as defendants, and was less likely to target individual physicians (9\% vs. $33 \%$ ) and hospitals ( $38 \%$ vs. $61 \%$ ). However, hospitals were still common targets for public enforcement, particularly with respect to merger activity amid the waves of consolidation that have buffeted the hospital sector since the early 1980s.

Compared to private litigation, public enforcement concentrated on policing corporate combinations ( $48 \%$ of public disputes), and maintained a substantial presence in insurance $(29 \%)$ and information $(13 \%)$ cases, while devoting few resources to exclusive contracting (10\%) or staff privileges (2\%) disputes (see Figure 1). Not a single litigated staff privileges case involved a public plaintiff, and the only case of public litigation involving hospital exclusive contracts was brought by a state attorney general, not the DOJ or FTC. This finding can be explained by one or more of the following: adequacy of private enforcement activity in such instances, lack of a broad effect of conduct in these areas on public welfare, unlikelihood of achieving a significant legal precedent, and the absence of true anticompetitive behavior or antitrust injury. Two FTC consent orders involved the conduct of hospital medical staffs denying or terminating staff privileges. The facts of these cases, however, differ substantially from those in most private suits. One case involved the categorical denial of privileges for nurse midwives and was pursued under a theory of preserving consumer choice. ${ }^{100}$ The other case involved a collective refusal by physicians to participate in a new HMO entering the market, combined with threats to terminate the privileges of any physician who joined the HMO network. ${ }^{101}$

Somewhat surprisingly, overall public enforcement did not differ from private litigation in terms of the geographic markets involved, although cases actually litigated by government enforcement agencies focused on relatively more isolated markets where concentration ratios are likely to be higher, and on larger national or global markets where substantial public interests may be at stake. Although the numbers were too small to assure statistical significance, more public than private cases ( $41 \%$ vs. $29 \%$ ) involved small cities or towns, and fewer (9\% vs. $32 \%$ )

100. See In re Med. Staff of Mem. Med. Ctr., No. 85I-0002, I987 FTC LEXIS $9, * 9$ (Oct. 6, 1987) ("Consumers have been limited in their ability to choose among alternative types of health care providers competing on the basis of price and service.").

101. See In re Addison, No. 871-0007, 1988 FTC LEXIS 69, at *5-*8 (Feb. I6, 1988). 
involved large cities and suburbs. Public plaintiffs were also more likely than private plaintiffs to litigate cases involving regional or national markets ( $45 \%$ vs. $33 \%)$.

Finally, the federal enforcement agencies tend to specialize. The DOJ monitored insurance companies and contracting intermediaries more closely than did other public enforcers, while the FTC took action more often against pharmaceutical and technology companies. ${ }^{102}$ The FTC dominated merger enforcement, pursuing 29 such cases compared to 9 for the DOJ. ${ }^{103}$ In part because FTC jurisdiction over nonprofit organizations outside of the merger context was not expressly confirmed by the Supreme Court until 1999,104 over two-thirds of the FTC's enforcement involved for-profit defendants, while the DOJ took action nearly two-thirds of the time against nonprofit defendants.

\section{Judicial Assessment of Quality}

The preceding results, though valuable, merely frame the central questions of our study: How do antitrust courts define and understand quality in health care (if at all)? How do courts analyze the effects of allegedly anticompetitive behavior on quality and similar considerations other than price? What quality related arguments are made and in what settings? To answer these questions, we reviewed the opinions in our sample for a range of legal and factual interpretations relating to nonprice competition.

As a preliminary matter, we attempted to determine how frequently courts explicitly articulate their assumptions about the effects of competition in health care markets. Unsurprisingly, relatively few opinions (101; $19 \%$ ) contained general statements of belief or disbelief in the benefits of health care competition. Of these, the majority expressed views consistent with prevailing economic analysis in the overall economy: 57 opinions stated that health care competition decreases prices, 15 that competition decreases costs, and 37 that competition increases quality. Despite the prominence given in the literature to "maverick" cases, we found very few opinions $(11 ; 2 \%)$ in which courts ventured unorthodox beliefs that health care competition increases prices ( 6 opinions), increases costs ( 7

102. Eighteen public enforcement actions in the sample involved pharmaceutical companies; 16 of these were brought by the FTC.

103. Of the 38 consent decrees involving mergers, 9 were brought by the DOJ, 5 by state attorneys general, and the remainder by the FTC. Only one DOJ merger consent decree involved a hospital merger. See United States v. Morton Plant Health Sys., Inc., No. 94-748-CIV-T23E, 1994 U.S. Dist. LEXIS 15352, at*4 (M.D. Fla. Sept. 29, 1994). The remaining DOJ merger cases involved medical devices and equipment. Nearly half of the FTC merger cases involved the pharmaceutical industry and typically resulted in partial divestiture or compulsory license agreements. The FTC also assumed responsibility for policing the merger activity of HCA/Columbia (producing 6 FTC consent decrees over a series of different transactions).

104. Cal. Dental, 526 U.S. at 767-68 (holding that the activities of a nonprofit professional association fall within the jurisdiction of the FTC Act). 
opinions), or decreases quality (3 opinions). Nor did many courts explicitly avail themselves of the leeway that Supreme Court precedent affords them regarding the health care industry. ${ }^{105}$ Only 16 opinions (3\%) stated that courts hearing health care antitrust cases should pay special attention to the professional issues involved, and only 11 courts (2\%) mentioned the social importance of health care as an analytic factor. Opinions issued in 1985-1989 were more likely to cite professional values than later opinions. Notably, 4 of the 13 opinions that expressed at least one of these countercurrent assumptions or special considerations involved nonprofit hospital mergers. ${ }^{106}$

Quality was discussed by courts as an attribute of competition in 436 passages, appearing in 194 different opinions (36\%). ${ }^{107}$ The incidence of quality discussions did not change from the beginning of our study period to the end. Adapting conventions from health economics and the

105. See Goldfarb v. Va. State Bar, 421 U.S. 773, 788 n.17 (1975). In Goldfarb, the court said:

The fact that a restraint operates upon a profession as distinguished from a business is, of course, relevant in determining whether that particular restraint violates the Sherman Act. It would be unrealistic to view the practice of professions as interchangeable with other business activities, and automatically to apply to the professions antitrust concepts which originated in other areas. The public service aspect, and other features of the professions, may require that a particular practice, which could properly be viewed as a violation of the Sherman Act in another context, be treated differently.

Id. It is possible that more courts will use the leeway afforded by Goldfarb following the Supreme Court's 1999 decision in Califormia Dental, 526 U.S. at 771 n.10 (reviving Goldfarb's footnote 17). See infra text accompanying note 187.

106. See HT1 Health Servs., Inc. v. Quorum Health Group, Inc., 960 F. Supp. 1104 (S.D. Miss. 1997); FTC v. Butterworth Health Corp., 946 F. Supp. 1285 (W.D. Mich. 1996); FTC v. Freeman Hosp., 911 F. Supp. 1213 (W.D. Mo. 1995); United States v. Carilion Health Sys., 707 F. Supp. 840 (W.D. Va. 1989). Significantly, two of the other cases involved judicial deference to legislative determinations about the possible adverse effects of health care competition. See Martin v. Mem'l Hosp., 86 F.3d 1391, 1399-1400 (5th Cir. 1996) (finding that suppression of competition in provision of end stage renal dialysis was beneficial and foreseeable result of state regulation under state action doctrine); Huron Valley Hosp., Inc. v. City of Pontiac, 650 F. Supp. 1325, 1337-39 (E.D. Mich. 1986) (granting defendants' motion for summary judgment and holding that defendants' conduct in attempting to deny plaintiff a "certificate of need" for new hospital was consistent with the planning mandate of governing legislation).

107. One of the most difficult aspects of case coding was to separate references to quality as a byproduct of competition from references to quality as a professional or technical issue. For example, cases involving denial of staff privileges often discuss the skill of the physicians in question because evidence of poor quality tends to explain the denial as other than anticompetitive. Few of these cases, however, assert that the hospital or the physicians associated with it will be more effective competitors by having protected the quality of the medical staff. In contrast, other courts expressly discuss how professional standards and qualifications are mediated through the marketplace. See, e.g., Koefoot v. Am. Coll. of Surgeons, 652 F. Supp. 882, 900-04 (N.D. lll. 1986) (discussing how professional society rules can enhance the market reputation of society members). This issue is addressed further in the discussion section. See infra text accompanying notes 183-187. 
health services research literature, we divided our inquiries regarding quality characteristics within health care firms into three groups: clinical structure, clinical processes (including clinical outcomes), and administration. ${ }^{108}$ In addition, we examined the opinions that mentioned quality to determine whether quality attributes were discussed in market or system terms, and whether those discussions focused on consumer choice or on other characteristics. Our results are shown in Figure 9.

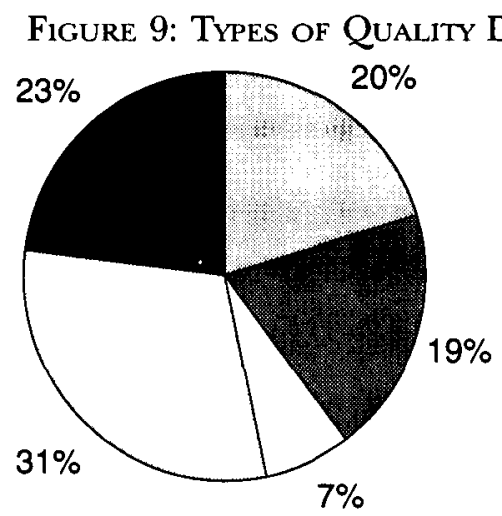

Discussed in Judicial Opinions

$\square$ Firm-level Clinical
Structure
Firm-level Clinical
Process
$\square$ Firm-level
Administration
$\square$ Health System or
Market Choice
Other System or Market
Characteristics

Although the difference was not statistically significant, slightly more opinions (134) mentioned quality as a market or system consideration as opposed to a firm-level consideration (122). Whether or not discussed in connection with a given firm, quality was frequently invoked as a general consideration (74 opinions) instead of being linked to specific manifestations of quality such as staffing, facilities, or technology. ${ }^{109}$ Outcome statistics, the gold standard for quality measurement in health services research, ${ }^{110}$ were mentioned only once. ${ }^{111}$ By contrast, malpractice claims

108. Cf. 1 Donabedian, supra note 32 , at $79-85$.

109. We coded a discussion of quality as "general" or "unspecified" even if another, unrelated part of the opinion contained a more specific discussion of quality, which was coded separately. Fifty-three separate opinions were coded as containing at least one or more abstract coding categories (section 5-3-7, 5-6-1, 5-7-8 or 5-7-9). See infra Appendix.

110. See generally 1nstitute of Medicine, Crossing the Quality Chasm: A New Health System for the 21 st Century 145-63 (2001).

111. See Angelico v. Lehigh Valley Hosp., Inc., 984 F. Supp. 308, 313-14 (E.D. Pa. 1997), rev'd by 184 F.3d 268 (3d Cir. 1999). Plaintiff alleged an antitrust conspiracy that coerced him to resign from defendant hospital and blacklisted him elsewhere. In assessing whether plaintiff's removal resulted in a reduction in quality and hence an antitrust injury under Brunswick Corp. v. Pueblo Bowl-O-Mat, Inc., 429 U.S. 477 (1977), the plaintiff's expert examined "raw data on mortality and ASG (admission severity group) supplied to hiin from the Pennsylvania Health Care Cost Containment Council" and found that "Dr. Angelico had equal or better mortality results in the aggregation of either of the other providers" at defendant hospitals. 984 F. Supp. at 313-14. The district court rejected these claims and other evidence regarding trends in mortality rates, ultimately finding that plaintiff had not established direct evidence of an anticompetitive effect and therefore lacked standing to pursue the clain. Id. at 314. The Third Circuit reversed, holding that 
against physicians, a notoriously poor indicator of quality but one with salience to courts (especially in staff privileges cases), were mentioned in 25 opinions. ${ }^{12}$

Paralleling their focus on markets and systems, courts discussed "horizontal" conceptions of quality-freedom of choice, range of products and services, geographic scope, and informed choice-in 96 opinions (18\%). These discussions were more common than ones involving "vertical" quality characteristics such as advanced facilities, skilled personnel, or reduced mortality. ${ }^{113}$ Static rather than dynamic views of quality dominated the opinions that contained quality related analysis: Only 6 opinions mentioned the potential for future quality improvement among firms, and only 7 opinions mentioned market or system-wide innovation and research.

Comparing cases that generated discussions of quality with those that did not reveals a few differences. First, opinions issues in connection with public litigation were much more likely to discuss quality than opinions issues in cases involving private plaintiffs $(71 \%$ vs. $34 \%)$. Possible explanations are that public enforcement focuses on more systematic threats to competition, and/or that the DOJ and the FTC are better prepared to make quality arguments. Second, opinions in cases with hospitals or physicians as plaintiffs were more likely to discuss quality than opinions in cases with pharmaceutical companies or insurance companies as plaintiffs. Sorting the data according to the identity of the defendants, the same trends were apparent but only hospital related cases achieved statistical significance, which suggests that plaintiffs have primary control over framing quality issues for courts. Third, the only detectable general influence of business conduct on quality related judicial analysis was that qual-

the district court failed to inquire into the existence of market power, which might support an inference of anticompetitive effect. 184 F.3d at 275-76.

112. Particularly in staff privileges cases, however, courts are often unclear as to whether denying privileges to a physician with a poor malpractice history should be regarded as beneficial to the hospital's competitive position, or merely supports the medical staff's contention that its decision was based on patient care rather than competitive concerns. See, e.g., Smith v. Ricks, 31 F.3d 1478, 1482 (9th Cir. 1994) (affirming dismissal of antitrust case with the court focusing on HCQIA and evidence of plaintiff's lack of medical competence as support for reasonableness of hospital's peer review action).

113. There may be some overlap here, however. An HMO or medical group practice that includes all potentially useful specialties can be both horizontally diverse and vertically superior. Cf. Blue Cross \& Blue Shield United of Wis. v. Marshfield Clinic, 65 F.3d 1406, 1412 (7th Cir. 1995). The court in Marshfield Clinic observed:

If an entire county has only 12 physicians, one can hardly expect or want them to set up in competition with each other. We live in the age of technology and specialization in medical services. Physicians practice in groups, in alliances, in networks, utilizing expensive equipment and support. Twelve physicians competing in a county would be competing to provide horse-and-buggy medicine. Only as part of a large and sophisticated medical enterprise such as the Marshfield Clinic can they practice modern medicine in rural Wisconsin.

ld. 
ity discussions occurred more often in corporate combination cases, and less often in the residual category that included pharmaceutical and other medical products cases. The latter finding raises the possibility that courts are failing to consider innovation as a quality concern in health antitrust litigation.

Turning to specific quality dimensions, opinions in staff privileges disputes were most likely to mention provider qualifications (an expected finding), and nearly all discussions of malpractice history as a quality concern arose in the context of staff privileges. Interestingly, staff privileges cases almost never discussed general firm reputation for quality or service, suggesting that, unlike exclusive contracting cases, courts approach these disputes as involving decisions by physician-competitors rather than the hospitals themselves. ${ }^{114}$

Different factors were associated with courts discussing choice as a quality attribute, although these discussions were again more common in public than in private litigation. Cases involving hospitals as plaintiffs or insurance companies as defendants, many of which related to selective contracting, were most likely to discuss choice. Cases with physicians as defendants, or pharmaceutical companies as plaintiffs or defendants, were least likely to discuss choice. Sorting by business conduct, discussions of choice were common in merger cases (loss of a competitor), exclusive contracting cases, and insurance cases (selective contracting), but were uncommon in staff privileges and "other" (medical products) cases.

Settlements by public enforcement agencies tend to offer less detailed analyses than most judicial opinions. Typically, all that is available is a copy of the complaint, a fairly terse competitive impact statement, and the actual consent decree or order which proscribes certain forms of conduct. In addition, these documents reflect the position of the enforcement agencies alone, whereas judicial opinions reflect the competing views of both sides to the dispute as filtered by a supposedly neutral arbiter. Nevertheless, discussions of quality occurred in 43 settlements

114. This finding is in some tension with the tendency of courts to invoke the intraenterprise conspiracy doctrine, which assumes a unity of interest between the hospital and its medical staff. Some of the tension is dispelled when the pragmatic function that the intraenterprise conspiracy doctrine plays is acknowledged. The intraenterprise conspiracy doctrine largely serves a screening function. Judges are highly skeptical of the antitrust merits of most staff privileges cases. The history of staff privileges case law is, in part, a study of the many strategies lawyers and judges have concocted to dismiss these cases early in the litigation process. At one point, it was fashionable to dismiss staff privileges cases on jurisdictional grounds, claiming an insufficient impact in interstate commerce. This tactic was ultimately rejected by the Supreme Court in Summit Health v. Pinhas, 500 U.S. 322, 330 (1991). A different strategy was to leverage various state mandates encouraging peer review into immunity under the state action doctrine. This tactic was rejected by the Court in Patrick v. Burget, 486 U.S. 94, 105 (1988), which required some level of active state supervision before immunity could be invoked. Today, the screening function is served through a combination of the antitrust injury requirement, the intraenterprise conspiracy doctrine, and federal protection afforded under HCQIA. 
$(52 \%)$, a higher frequency than in private litigation (172 opinions; $34 \%$ ). For both the DOJ and the FTC, quality discussions tended to relate to markets (46 coded entries) rather than to firms (13 coded entries)..$^{115}$ Choice was discussed in 20 settlements (24\%), again more often than in private litigation (84 opinions; $16 \%$ ). Surprisingly, more discussions of innovation as a dimension of quality were found in this small group of public settlements (9 entries) than in the much larger sample of judicial opinions that we reviewed ( 7 entries)..$^{116}$

\section{Discussion of Legal and Policy Implications}

The empirical research described in this Article was motivated by a desire to test three assumptions we held about the role of antitrust law in health care. We initially posited (1) that antitrust litigation plays a useful role by promoting price competition in medical markets, (2) that medical antitrust law is substantially influenced by the actions and policies of the federal enforcement agencies, and (3) that medical antitrust law does not adequately address quality and nonprice concerns. ${ }^{117}$ Our results

115. Of the 7 state attorney general consent decrees in our sample, admittedly a very small number, only two mentioned a specific attribute of quality, both focusing on provision of charity care. See Wisconsin v. Kenosha Hosp., 1997-1 Trade Cas. (CCH) I 71,669, at 71,669 (E.D. Wis. Dec. 31, 1996) (permitting hospital merger but committing the hospitals to establish an indigent care fund); Pennsylvania v. Capital Health Sys. Servs., 1995-2 Trade Cas. (CCH) I 71,205, at 71,205 (M.D. Pa. Dec. 15, 1995) (premising approval of merger on commitment that some portion of the efficiencies attributed to the merger go to provide services to the underserved).

116. The results pertaining to innovation are driven, in part, by pharmaceutical cases. Five of the six FTC codes for considerations of technological or organizational innovation come from consent decrees with drug companies. It is not surprising that innovation is a particularly important concern in this setting, where research and development is essential and where the core concern of intellectual property is the creation of incentives to encourage innovation. Significantly, the enforcement agencies' concern for innovation is not limited to this line of cases. Innovation is invoked as a concern in nonpharmaceutical cases and with respect to factors that go beyond technology to encompass organizational form; for example, the transition to various forms of managed care is a type of organizational innovation.

117. These assumptions derived in part from our familiarity with "leading cases" in health care antitrust as presented in the health law casebooks. Comparing such cases to the full litigation landscape is a useful exercise. As previously noted, we applied our coding instrument to the antitrust cases reported in the major health law casebooks to confirm the instrument's utility before embarking on the much larger endeavor of coding all published opinions. Although there is no reason to believe that the sample of casebook cases should mirror the larger universe of medical antitrust cases, it is interesting to note how the view of the world and the law reflected in the leading casebooks compares to our findings generally.

The casebook sample consisted of 26 cases, some of which are not in our larger sample because they were decided before I985. The casebook sample suggests that goverument suits are four to five times more common than they in fact are, that antitrust disputes with managed care defendants account for a third of all cases, and that litigation against professional and trade associations accounts for nearly $30 \%$ of health care antitrust disputes. Staff privileges and exclusive contracting cases are well represented, but account 
support the third hypothesis, but cast doubt on the first and second. Our data reveal that federal medical antitrust cases resulting in judicial opinions are mostly private, not public. Despite the rise of managed care, judicial dockets remain dominated by litigation between physicians and hospitals. This antitrust litigation disproportionately involves the denial of staff privileges and the legality of exclusive contracts to deliver clinical services. Moreover, very few private suits succeed. These findings raise questions about the social utility of private medical antitrust litigation, the manner in which public enforcement functions to influence behavior in health care markets if not through the federal courts, and the importance of antitrust law to markets dominated by managed care, which are also the markets in which quality is most vulnerable to the competitive process. In this Part, we discuss the connections between our empirical results and these broader legal and policy questions, both generally and with specific attention to the issue of quality competition.

\section{A. Is Medical Antitrust Litigation Socially Useful?}

The American system of antitrust law is premised upon an overlapping system of public and private enforcement. Not only may private citizens sue for violations of federal antitrust law, but they are given added incentives to do so in the form of treble damages and compensation for their attorneys' fees if they are successful. Because government's enforcement resources are limited, it should not be surprising that the vast majority $(94 \%)$ of health care antitrust disputes that resulted in judicial

for one-fifth rather than two-thirds of the cases. As with most casebook collections, one gets the impression that district courts do not exist $(88 \%$ of the cases are appellate level decisions). More significantly, one gets the impression that plaintiffs and defendants are more evenly matched than they in fact are. While twice as many appeals are by plaintiffs rather than defendants-suggesting more rulings adverse to plaintiffs at the district court level-plaintiffs enjoyed favorable outcomes in $30 \%$ of the casebook sample, while defendants enjoyed favorable outcomes in $40 \%$ of cases.

There are important similarities as well. The casebook sample gives a fair representation of the types of legal analyses courts perform, including a strong tendency towards structural economic analysis, a sensitivity to alleged efficiencies and procompetitive effects, and a significant role for defenses such as state action and the intraenterprise conspiracy doctrine. The casebook sample understates the role of the antitrust injury doctrine, but this is not surprising because largely meritless cases screened out by that doctrine do not make good teaching material. Interestingly, possibly as a byproduct of the overrepresentation of professional and trade association cases, the casebook sample substantially overstates the significance of Goldfarb-era concerns.

The casebook sample fairly represents judicial treatment of quality concerns. As in the larger sample, there is a nearly even split between firm-specific and market-level quality discussions. Concerns dominant in the health services research literature are found in neither sample. The quality related factors that arise in the casebooks resonate more broadly with courts: the qualifications of health care providers, malpractice, and the seemingly ubiquitous "unspecified quality of patient care concerns." On the market level, the casebook cases accurately suggest the importance of information and choice in courts' antitrust analysis, but these cases credit courts with a sensitivity to technological and organizational innovation somewhat greater than occurs in the world at large. 
opinions between 1985 and 1999 were brought by private parties. Previous studies of general antitrust litigation find similar splits between private and public plaintiffs. The Georgetown Antitrust Project reports that from the mid-1960s to the late $1970 \mathrm{~s}$ only $5 \%$ of antitrust cases filed in federal court were brought by the FTC or the DOJ. ${ }^{118}$ ln the 1980s, largely due to overall reductions in the number of private suits rather than increased public enforcement, $10 \%$ of all cases were brought by the two federal agencies. ${ }^{119}$

1. Private Litigation. - What motivates private parties to bring these suits? If we assume plaintiffs are rational economic actors, a private suit will be brought only if the expected gains in damages and/or injunctive relief exceed the expected costs of litigation. ${ }^{120}$ Antitrust law skews these

118. Salop \& White, supra note 15 , at 3 .

119. Id. Similar numbers are reported elsewhere, though none of those studies focus as we do on health care litigation. A GAO Report on changes in federal antitrust enforcement found that between 1980 and 1989, private cases constituted $91 \%$ of all antitrust cases filed in district courts. See GAO Report, supra note 17, at 14; see also NERA, Antitrust Report, supra note 16, at 1 (finding that in 1970-1978 between $93 \%$ and $96 \%$ of cases filed in district court were brought by private plaintiffs). Historic public/ private trends can be found in Posner, supra note 18, at 373. Between 1890 and 1940, the number of public and private cases filed were comparable. Id. Beginning in the 1940 s and continuing to 1969 , private antitrust filings began to substantially outpace public filings, which remained roughly constant. Id. Some caution should be exercised in comparing these sets of numbers with the results of our survey. Our survey examined medical antitrust cases, not antitrust litigation generally. Our survey was limited to cases that resulted in judicial opinions and thus did not include all district court filings. Our survey included cases brought by state attorneys general, an aspect of public enforcement not specifically included in the earlier studies. Finally, the exact percentage of public versus private suits in our study is sensitive to the inclusion or exclusion of public consent decrees. If both DOJ and FTC consent decrees are added to the mix, the percentage of public cases rises to $19 \%$ of the total sample in our study.

120. In economic models of litigation, the decision to sue, the decision to settle, and decisions concerning the amount of resources to devote to litigation are premised upon a series of interconnected cost benefit calculations. A number of models have been developed with the specific aim of studying antitrust settlement practices. See Baxter, supra note 18, at 11-26; Jeffrey M. Perloff \& Daniel L. Rubinfeld, Settlements in Private Antitrust Litigation, in Private Antitrust Litigation, supra note 15, at 149, 150-61; Salop \& White, supra note 15, at 16-24; see also John C. Coffee, Jr., Understanding the Plaintiff's Attorney: The Implications of Economic Theory for Private Enforcement of Law Through Class and Derivative Actions, 86 Colum. L. Rev. 669, 698-701 (1986) (finding that trials occur only when one party is overly optimistic and thus prevents agreement on litigation odds); Theodore Eisenberg, Litigation Models and Trial Outcomes in Civil Rights and Prisoner Cases, 77 Geo. L.J. 1567, 1570-72 (1989) (stating that expectation theory predicts that "objectively strong and weak cases do not reach trial"); Priest \& Klein, supra note 45, at 6-17 (using selection effect to show that parties' estimates of success drive litigation and differences in estimates cause nonsettlement). The basic insight from these economic models is fairly straightforward. Plaintiffs initiate suits when they believe that the expected value of their damage award will be greater than the expected costs of litigation. Within these models, cases will normally settle if plaintiffs and defendants have sufficiently convergent estimates of the value of the case (amount of damages), the legal principles governing the dispute, and the probability of success. Litigation is typically a sign of divergent expectations between the parties. However, where either party has incentives 
calculations in favor of suing by increasing the potential payoff and decreasing the expected costs of litigation by its fee shifting provision. Moreover, in addition to treble damages and attorney's fees, antitrust law empowers courts to provide extensive equitable relief (with more liberal standing and antitrust injury requirements than are required in damage actions). Any anticipated benefits of litigation, however, must be discounted by the expected probability of a successful outcome, which in our sample is quite low even using an expansive definition of success. The private parties in our study gained successful court outcomes only $14 \%$ of the time. ${ }^{121}$ Courts very rarely awarded damages and infrequently granted equitable relief. If one looks specifically at staff privileges cases, plaintiff success rates are particularly dismal. Plaintiffs receive favorable outcomes in staff privileges cases only $7 \%$ of the time. Our data on appellate opinions confirm our finding that plaintiffs are unsuccessful at the lower court level. Plaintiffs brought 168 appeals, whereas defendants appealed from adverse trial rulings on 39 occasions. Appellate opinions sustained trial rulings adverse to defendants only 5 times in private suits. Our findings mirror recent work by Jacobson, Selvin, and Pomfret, who conducted an empirical assessment of the relationship between health care litigation generally and health policy. ${ }^{122}$ In their much smaller sample of 47 medical antitrust opinions, courts ruled for plaintiffs in $24 \%$ and for defendants in $67 \%$, with $9 \%$ representing "partial" rulings-results roughly comparable to our own. ${ }^{123}$ The low rate of plaintiff victories

that go beyond the context of the dispute in question, such as a concern about how settlement of the present case might affect future litigation, it can produce different outcomes.

121. In drawing conclusions from these data, it is important to keep in mind the limitations of our methodology. First, as discussed earlier, we have no means of comparing our results from written opinions with the category of cases that settle. Second, even with respect to litigated cases, we only examine cases that generated a judicial opinion. There is no necessary reason that a plaintiff's (or defendant's) jury verdict will be included in our sample. The question, therefore, is whether the win-loss ratios derived from examining opinions accurately reflect the win-loss ratios in the universe of all litigated medical antitrust cases. Verdicts will be reported in opinions primarily if challenged by post-trial motions or if appealed. If plaintiffs and defendants have identical incentives to bring posttrial motions and appeals, then the trial outcomes reported in opinions should not be subject to any systematic selection bias. If the defendant's stakes in an adverse ruling are higher than the plaintiff's, then opinions would disproportionately report plaintiff trial victories. If antitrust plaintiffs as a class have fewer resources relative to antitrust defendants, and resources are positively correlated with the decision to seek review, then one would expect relatively fewer plaintiff challenges to adverse outcomes. Under either of these scenarios, we believe that if a selection bias does exist in our focus on judicial opinions, it would suggest that the low rates of plaintiff victories we report may actually represent an upper bound.

122. Jacobson et al., supra note 40, at 3-4. The Jacobson study also evaluated litigation involving ERISA, medical necessity, utilization review, and technology assessment.

123. Id. at $15,29-30$. 
found in our sample is also generally consistent with earlier studies of non-health care antitrust litigation. ${ }^{124}$

What explains the large number of private suits despite very low probabilities of success, and what do possible explanations imply about the social utility of private antitrust litigation in health care? First, assuming that our results are not simply the artifacts of a publication or settlement bias, these findings are consistent with the incentive effects of potentially high antitrust payoffs. The promise of treble damages, attorney's fees, and injunctive remedies may attract plaintiffs at the margin with weaker cases than would be the case if the payoffs were reduced. A possible analogy is medical malpractice litigation. According to one study, plaintiffs in medical malpractice suits were significantly less likely to prevail than other personal injury plaintiffs sustaining similar injuries, but damage awards in successful cases were approximately twice as high. ${ }^{125}$ In our study, however, so few cases generated damages or equitable relief with clear commercial value that we hesitate to endorse this hypothesis with respect to medical antitrust litigation. Publicity from early staff privileges cases with large damage awards, such as Patrick $v$. Burget, ${ }^{126}$ may have misled plaintiffs into overestimating their likely gains from litigation. However, such an effect would be short-lived, and our data show that the frequency of such cases remained fairly high throughout the study period. On the other hand, private staff privileges cases did decline from $51(39 \%)$ in 1985-1989 to 34 (28\%) in 1995-1999 (see Figure 2). The reduction in the later periods may have been caused by persistently

124. The Georgetown Antitrust Project found that $73.3 \%$ of all cases filed in their sample settled or were dismissed, and only $2.8 \%$ resulted in a judgment for some or all plaintiffs. Salop \& White, supra note 15 , at 10 . In contrast, $7 \%$ of all filed cases resulted in a judgment for one or all defendants. Id. Considering only cases in the Georgetown sample that went to judgment, plaintiffs prevailed in $28 \%$ of all cases (reduced to $11 \%$ if the dismissal of the case is considered to be a defendant victory, a characterization more consistent with our methodology). Id. at 16. The NERA study found that plaintiffs won only $2 \%$ of all filed cases, where a victory reflected either a trial verdict in their favor or a defendant's default. NERA, Antitrust Report, supra note 16, at 44. Defendants received judgments in $14 \%$ of all filed cases, including summary judgment motions, motions to dismiss, and victories at trial. 1d. If one looks only at cases proceeding to judgment, plaintiffs prevailed in $12 \%$ of cases in the NERA sample. ld. In comparing our results to those of the Georgetown Antitrust Project and the NERA study, the difference in our definition of a "plaintiff victory" must be kept in mind. Other studies of antitrust litigation define a plaintiff victory in terms of an actual judgment, such as a trial verdict or a default judgment. Our definition of a plaintiff victory is much broader. For both plaintiffs and defendants, we define a victory to include not simply judgments, but also prevailing in other respects, such as winning or losing a motion for summary judgment or a motion to dismiss. Perhaps most significantly, we treat the denial of a defendant's motion for summary judgment as a plaintiff's victory. The net effect of our approach would be to over-report the degree of plaintiff success rates as compared with earlier studies.

125. Randall R. Bovbjerg et al., Juries and Justice: Are Malpractice and Other Personal Injuries Created Equal?, 54 Law \& Contemp. Probs. 5, 16-21 (1991).

126. 486 U.S. $94,98-99$ (1988) (upholding a jury verdict awarding plaintiff nearly two million dollars in treble damages). 
low success rates or the Health Care Quality lmprovement Act of 1986,127 which granted peer review bodies limited antitrust immunity and provided for recovery of attorney's fees by prevailing defendants.

It is possible that prevailing plaintiffs earn rewards outside of court or in collateral proceedings that increase the potential payoff from litigation in ways that are not reflected in our data. Strong cases may be the very cases that settle, thereby skewing our results. It would be useful to know whether the mere fact of filing suit pressured hospitals to admit or reinstate a complaining physician to the medical staff, even though one would expect the negotiating value of such an action to be slight if the defendant is aware of how unsuccessful these antitrust claims are. We see no particularly strong strike value to these claims. The cost of trying a staff privileges case should not be inordinately high for the hospital, particularly given the availability of screening devices such as the antitrust injury doctrine to dispose of weak cases early in the process. Alternatively, the antitrust claim may simply be one of many legal theories being pursued against the hospital, with others consisting mainly of state tort and contract claims. From this perspective, a federal antitrust claim may be part of a larger mix, with the Sherman Act claims serving as a means to anchor the dispute in federal rather than state court. ${ }^{128}$

127. 42 U.S.C. $\$ \$ 11,101-11,152$ (1994).

128. Many staff privileges cases combine state tort and contract claims with a federal antitrust claim. On rare occasions, the plaintiff succeeds on all fronts. $\ln$ Brown $v$. Presbyterian Healthcare Services, for example, a physician sued a hospital after revocation of staff privileges on antitrust and state tort theories. 101 F.3d 1324, 1327-28 (10th Cir. 1996). The jury found in favor of the plaintiff on both theories. 1d. at 1328. In other cases, the plaintiff may win the state common law claim, but lose the federal antitrust claim. In Johnson v. Hospital Corp. of America, practitioners of environmental medicine sued on state tort and federal antitrust grounds for revocation of their staff privileges and the subsequent closure of the Environmental Medicine Unit. 95 F.3d 383, 386-87 (5th Cir. 1996). The district court found a violation of state tort law and awarded compensatory and punitive damages, but found no antitrust violation. The Fifth Circuit affirmed the finding of no antitrust liahility but reversed a portion of the damage award on the state tort theory. 1d. at 393, 395-96; see also Robles v. Humana Hosp., 785 F. Supp. 989, 999, 1002-03 (N.D. Ga. 1992) (granting defendants summary judgment as to antitrust claims but denying summary judgment on state tort and contract theories in staff privileges case). In the majority of instances, however, the federal antitrust claim is dismissed and the court declines to exercise jurisdiction over the state causes of action. See, e.g., Alba v. Marietta Mem'l Hosp., 184 F.R.D. 280, 290 (S.D. Ohio 1998) (granting summary judgment on tbe antitrust claim and declining to exercise pendant jurisdiction over state law claims in staff privileges case), aff'd, 202 F.3d 267 (6th Cir. 2000); Mathews v. Lancaster Gen. Hosp., 883 F. Supp. 1016, 1047 (E.D. Pa. 1995) (granting defendants summary judgment on antitrust claims and declining to exercise jurisdiction over state law claims in dispute between orthopedic surgeon and hospital peer review board), aff'd, 87 F.3d 624 (3d Cir. 1996); Willman v. Heartland Hosp. East, 34 F.3d 605, 612-613 (8th Cir. 1994) (affirming district court's grant of summary judgment for defendants on antitrust claims and finding that district court did not abuse discretion in declining to hear state law claims); Flegel v. Christian Hosp. Northeast-Northwest, 804 F. Supp. 1165, 1175-76 (E.D. Mo. 1992) (granting defendants summary judgment on antitrust claim and declining to exercise jurisdiction over state law claims in case involving changes in hospital bylaws that would 
A second possible explanation involves the asymmetry of payoffs rather than their absolute level. One of the more interesting predictions of the Priest-Klein settlement model is that the outcomes of litigated cases should favor each party about half the time. ${ }^{129}$ The fact that the win/loss ratio for private antitrust plaintiffs diverges substantially from this prediction is well known and has been widely noted. ${ }^{130}$ The most commonly suggested explanation for the historically low rate of plaintiff victories is that the stakes in most antitrust cases are highly asymmetric. Defendants often have more to lose in antitrust litigation than the plaintiffs stand to gain, a fact that violates one of the basic assumptions of the Priest-Klein model. Defendants may be worried about reputational effects of litigation and the effect that an adverse ruling or onerous injunctive relief could have on a wide range of their business practices. ${ }^{131}$ When the defendant has more to lose than the plaintiff has to gain, the model predicts both a higher rate of settlement and a lower rate of plaintiff victories, because defendants will only go to trial on those cases where they are fairly confident of victory. ${ }^{132}$

Asymmetric stakes are likely present in some of our health care antitrust cases as well. As in other industries, the broad equitable powers of antitrust courts expose defendants to the risk of costly injunctive relief. Defendants may also care more about reputational effects, both generally and in connection with provoking additional lawsuits. Still, at least in the setting of staff privileges and exclusive contacting cases, it is unlikely that a single hospital will be a repeat defendant in the same manner as a national manufacturer facing a steady stream of dealer termination cases. Similarly, the stakes for the discharged physician in terms of professional reputation and economic livelihood can be quite substantial as well.

result in categorical exclusion of osteopaths), aff'd, 4 F.3d 682 (8th Cir. 1993). Similar patterns can be observed in exclusive contracting cases. See, e.g., Diaz v. Farley, 15 F. Supp. 2d 1138, 1150 (D. Utah 1998) (granting defendants summary judgment and declining to exercise jurisdiction over the state law claims in dispute between groups of anesthesiologists), aff'd, 215 F.3d 1175 (10th Cir. 2000).

129. Priest \& Klein, supra note 45 , at $17-20$. In predicting an even win/loss ratio in litigated cases, the model assumes that litigation is more costly than settlement, id. at 13 , that the parties will make comparable types of errors in estimating outcomes, id. at 19, and that the parties' stakes in the litigation are symmetrical, meaning that the damage award the plaintiff stands to win represents the full and complete anticipated loss to the defendant. Id. at 12.

130. See, e.g., Baxter, supra note 18, at 16-20 (discussing how historic plaintiff win/ loss ratios in private antitrust litigation violate an analogous 50-50 hypothesis suggested by Baxter's own settlement model); Coffee, supra note 120, at 698-701 (noting the paradox of historically low plaintiff win rates in antitrust cases in the context of the Priest-Klein model); Eisenberg, supra note 120, at 1579-80 (same); Priest \& Klein, supra note 45, at 52-54 (discussing the unusually low rate of plaintiff victories in private antitrust cases in the context of their selection model); Salop \& White, supra note 15, at 25-26 (same).

131. Perloff \& Rubinfeld, supra note 120 , at 156.

132. Priest \& Klein, supra note 45 , at $25-26$. 
While certainly germane, the asymmetric stakes explanation alone does not seem to fully explain either the steady volume or the incredibly low rate of success in these cases. ${ }^{133}$ The standard Priest-Klein model predicts that the volume of litigated cases will decline as increased certainty about the legal rule leads to a greater convergence in the parties' expectations and an increase in settlement. Given the ongoing structural transformation of the health care sector, however, it is easy to imagine that there are sufficient new sources of uncertainty to outweigh any uncertainty reducing effect of previously litigated cases.

A third set of possible explanations involves relaxing the rational actor assumption as applied to physicians, or at least building into the physician's utility function elements not normally associated with engaging in litigation. This might be thought of as the "big ego/big wallet" or "big fish/little pond" explanation. ${ }^{134}$ Under this view, staff privileges cases and perhaps other cases are brought because they affect deeply personal and important aspects of the physician's reputation or competence and the physician has the financial resources to subsidize the litigation. ${ }^{135}$ Especially in small communities, antitrust litigation frequently has as much

133. Some might claim that asymmetric information rather than asymmetric stakes explains the persistently low plaintiff win/loss ratios. In the presence of asymmetric information, almost any win/loss ratio can be generated in the Priest-Klein settlement model. Steven Shavell, Any Frequency of Plaintiff Victory at Trial is Possible, $25 \mathrm{~J}$. Legal. Stud. 493, 500-01 (1996). It is doubtful that the existence of information asymmetries has much explanatory power in our sample beyond the issues of rationality and representation discussed below. Aside from the wide range of cases where equally sophisticated parties are on both sides of the litigation-hospital versus hospital, insurance company versus insurance company, pharmaceutical company versus pharmaceutical company, or even hospital versus insurance company-the asymmetric information explanation is largely unpersuasive even for the more limited context of staff privileges cases (physicians versus hospitals). As already noted, typical hospital defendants are unlikely to be very experienced in antitrust litigation. Neither do physicians resemble indigent plaintiffs or plaintiffs in medical malpractice suits. Each side in the physician-hospital dispute has economic resources and each side can purchase expertise in the market. The relevant information is itself a ready commodity-professional legal services. Outside counsel retained by hospitals may be better trained than lawyers representing individual physicians. However, these are not particularly difficult cases from an antitrust perspective and not an area where there would be substantial question as to the appropriate legal advice.

134. Some plaintiffs truly seem to have wandered through the looking glass. In one case, a surgeon in rural Idaho sued two hospitals for allegedly agreeing not to recruit additional surgeons into the community because reduced competition among surgeons forced him to work too hard. Patton v. E. Idaho Reg'l Med. Ctr., No. 92-36805, 1994 U.S. App. LEXIS 3192, at*2 (9th Cir. Feb. 18, 1994). The court commented: "Although it may have been foreseeable that the alleged conspiracy would result in Dr. Patton's overwork and stress, this . . . is not a cognizable antitrust injury." Id. at *7.

I35. This pattern extends beyond antitrust litigation to other legal claims. Because of the strong personalities, high moral tone, and large financial stakes in health care, internecine feuds among physicians often spill over into the courts. The first part time job that one of the authors had in law school involved reviewing medical records in malpractice litigation based on data on poor cardiac surgery outcomes that the medical cardiologists at a major academic center in California, who were in the midst of a bitter turf battle with the surgeons, had leaked to the press. 
to do with personal animosity as economic injury. ${ }^{136}$ Furthermore, physicians in solo or small-group practice may feel that being denied access to their preferred hospital in a new town (staff privileges cases) or being shut out of the hospital in which they are accustomed to practicing (exclusive contracting cases) is tantamount to costing them their livelihood, and may be willing to go to substantial lengths to prevent it. Exclusive contracting cases may have additional symbolic importance to physicians. While staff privileges disputes are typically triggered by fellow physicians' efforts to remove a colleague who is incompetent and/or incorrigible, exclusive contracting cases reflect a fundamental restructuring of the marketplace that shifts economic power and decisionmaking authority from physicians to hospitals. ${ }^{137}$

A last set of possible explanations involves agency failure in the legal profession. Are the lawyers who agree to represent these physicians, and who presumably know the slim odds they face, failing in their counseling role, or are their clients simply too stubborn to listen to good advice? It would be enlightening to know more about the fee structures used by plaintiffs' attorneys in medical antitrust cases. One might speculate that the pro-plaintiff fee shifting provisions of the federal antitrust laws tempt lawyers into misleading the physicians paying their hourly rates that the fees will ultimately be covered by defendants. One also wonders how many of these cases would be brought if the plaintiffs' attorneys had to undertake the claim on a contingency fee basis. In any event, the lack of attorney self discipline suggested by our data makes us doubt that sound client counseling regarding antitrust obligations and liabilities is taking place, or that the public ends of antitrust law are necessarily being furthered by the actions of the private bar. ${ }^{138}$

On the positive side, our survey suggests that courts recognize the weaknesses of most medical antitrust claims and are fairly effective in

136. The histrionics portrayed by the parties in Wright v. Southern Mono Hospital District are perhaps extreme, but far from unique: "[Dr.] Stehlik [was] accused of severely breaching good interprofessional conduct and physically threatening Dr. Paulson, his wife, and unborn child. ... [And] Dr. David Matthews ... and Dr. Stehlik engaged in a fist fight behind closed doors in the radiology suite at Mammoth Hospital." 631 F. Supp. 1294, 1298 (E.D. Cal. 1986), aff'd sub nom. Stehlik v. S. Mono Hosp. Dist., 924 F.2d 1063 (9th Cir. 1991). For additional pathos, the court goes on to note that "[a]t the present time, there are no witnesses to the altercation, independent or otherwise. . . Dr. Matthews was killed in a single aircraft collision. . . . Dr. Stehlik committed suicide." Id. at 1299 n.3.

137. This was particularly true for cases that arose during the $1990 \mathrm{~s}$, when hospital finances were strained and competition intense. Some of the earlier cases involved battles between rival physician groups for control of hospital departments, with the hospital caught in the crossfire, rather than placing the hospital in a position of economic and clinical authority.

138. See Coffee, supra note 120, at 684-90 (discussing how methods of attorney compensation can undermine the public integrity of various private attorney general provisions). 
weeding them out. ${ }^{139}$ According to the GAO, the total number of private antitrust cases (in all industries) filed in federal district courts fell over $50 \%$ (from 1,292 to 638) between 1981 and 1989. ${ }^{140}$ Many attribute this dramatic decline to increasing reliance by courts on structural economic analysis (the express examination of market definition and assessments of market power) and the use of standing limitations and screening devices such as the antitrust injury doctrine. While our research does not document a decline in the number of medical antitrust cases being brought over the fifteen-year period we studied, it does document judicial use of various doctrinal devices to screen out weak cases, to frame the legal issues in contested cases, and to distinguish disputes raising concerns germane to antitrust law from disputes that are better addressed in legislative or administrative fora, or as a matter of state common law. The antitrust injury doctrine stands out in our data as the most effective such heuristic. $^{141}$

Although social resources are arguably wasted in the process of litigating these cases, medical antitrust disputes are not necessarily generating bad outcomes, or systematically curious results. ${ }^{142}$ The exclusive contracting cases, for example, reflect a move away from a "physician workshop" model of hospitals and toward an integrated vertical relationship between hospitals and suppliers of certain physician services, such as radiology, anesthesiology, pathology, and emergency medicine. As noted above, courts have readily acknowledged the efficiencies and improved quality of services often associated with such contracts. ${ }^{143}$ From this perspective, suits challenging exclusive contracting can be understood as efforts to use the antitrust laws to preserve traditional power relations and streams of economic benefits in health care. Such a tactic is neither unique to health care nor necessarily improper. In rejecting most of these claims, courts have projected onto the health care sector the same economic assumptions they make about the efficiency of vertical relations and nonprice restraints elsewhere in the economy. ${ }^{144}$ Arguably, this has helped facilitate further, socially appropriate market restructuring.

139. This claim has some obvious normative overtones. It is based upon our interpretation of the survey results in conjunction with our systematic review of tbe cases. In reviewing the cases, one obtains a fairly strong instinct for what constitutes a strong or a weak claim. One also gains a fair amount of respect for how courts have used structural economic analysis, a sensitivity to efficiency claims in appropriate settings, and the full range of immunities and defenses available in antitrust law, admittedly blunt instruments in and of themselves, to screen cases lacking in substantive merit and to identify those cases most likely to present a threat to competition.

140. GAO Report, supra note 17 , at 4 .

141. Antitrust injury or standing was addressed in $45 \%$ of the opinions we studied. See supra text accompanying notes 93-95.

142. The same type of caveats we make in footnote 139 about the normative nature of this claim apply here as well.

143. See infra text accompanying notes 174-175.

144. In non-health care setcings, vertical nonprice restraints are evaluated under the rule of reason as a matter of course, see Continental T.V., Inc. v. GTE Sylvania Inc., 433 
Still, it would be a stretch to conclude that private health care antitrust litigation between 1985 and 1999 produced substantial social benefits. Such litigation was common, and comprised a large and growing proportion of antitrust lawsuits as a whole. Most cases were losers and were dismissed at early stages of review. It remains possible that buried in our data are a handful of cases with real impact, but relatively few private cases in our sample pose "big questions" about the optimal structure of the health care industry. Rather, most of the antitrust litigation we observed was mired in a thicket of physician-hospital relations. The subset of cases involving pharmaceuticals and other medical products seems more analytically interesting than the larger universe of physician and hospital disputes, ${ }^{145}$ perhaps presaging a series of decisions in the future as large insurers and other managed care companies have their day in

U.S. 36, 36-37 (1977), with a strong presumption that such restraints are efficient. See Bus. Elecs. Corp. v. Sharp Elecs. Corp., 485 U.S. 717, 726 (1988). This same template is now being applied in many hospital exclusive contracting cases. See, e.g., Coffey v. Healthtrust, Inc., 955 F.2d 1388, 1392-93 (10th Cir. 1992) (characterizing the relationship between the defendant hospital and its physicians as vertical in nature and therefore subject to rule of reason analysis).

145. An important trend in pharmaceutical litigation involves challenges to systems for pricing and distributing prescription drugs. See, e.g., In re Brand Name Prescription Drugs Antitrust Litig., 123 F.3d 599, 603, 616 (7th Gir. 1997) (blocking effort by small retail pharmacies to challenge the pricing structure created by large purchasers and managed care plans negotiating special deals for prescription drugs); Barton \& Pittinos, Inc. v. SmithKline Beecham Corp., 118 F.3d 178, 179 (3d Cir. 1997) (affirming summary judgment against plaintiff in antitrust litigation over the wholesale distribution of hepatitis$B$ vaccine to nursing homes); Burlington Drug Co. v. VHA, Inc., No. 2:95-CV-15, 1998 U.S. Dist. LEXIS 17787, at *2-*3 (D. Vt. Sept. 3, 1998) (granting plaintiff drug company's motion for defendant health care organization to supplement discovery in antitrust litigation over wholesale distribution of pharmaceuticals and jointly negotiated price discounts); Merck-Medco Managed Care, Inc. v. Rite Aid Corp., 22 F. Supp. 2d 447, 450 (D. Md. 1998) (alleging conspiratorial boycott by defendant pharmacies to undermine plaintiff's efforts to build pharmacy network), aff'd, 201 F.3d 436 (4th Cir. 1999); FTC v. Cardinal Health, Inc., 12 F. Supp. 2d 34, 36-37 (D.D.C. 1998) (enjoining a proposed merger between two large wholesale drug distributors); Rudner v. Abbott Labs., Inc., 664 F. Supp. 1100, 1101 (N.D. Ohio 1987) (involving Robinson-Patman Act price discrimination claim against pharmaceutical manufacturer).

A second important trend involves disputes between the manufacturers of brand name and generic drugs. Some of this litigation implicates conduct before the FDA at the market/regulatory interface. See Cheminor Drugs, Ltd. v. Ethyl Corp., 168 F.3d 119, 120 (3d Cir. 1999) (finding that alleged misrepresentations by defendant did not vitiate NoerrPennington immunity for petitioning the government to protect it against imports of bulk ibuprofen by plaintiffs); Mylan Labs., Inc. v. Akzo, N.V., 770 F. Supp. 1053, 1058 (D. Md. 1991) (alleging improprieties in securing FDA approval of generic drugs). Other cases challenge marketing tactics. See, e.g., Nat'l Ass'n of Pharm. Mfrs., Inc. v. Ayerst Labs., 850 F.2d 904, 906 (2d Cir. 1988) (seeking review of dismissal of antitrust and Lanham Act claims by generic drug manufacturer against brand name drug manufacturer for circulation of letter to pharmacies discussing possible dangers of generic drug substitution). Occasional cases pit competing prospective manufacturers of generics against each other. See Invamed, Inc. v. Barr Labs., Inc., 22 F. Supp. 2d 210, 214-15 (S.D.N.Y. 1998) (alleging anticompetitive behavior by affiliated entities in suit between rival prospective generic drug producers of warfarin sodium). 
court. Nonetheless, our results strongly suggest that we must look beyond the private litigation of the past fifteen years to find antitrust analysis that is robust enough to accomplish our policy goal of incorporating both quality and price considerations into health care competition.

2. Public Enforcement. - To a degree, the conclusion of the preceding Section is unsurprising. There is no reason to believe that the self interest of private parties who can claim standing under the antitrust laws will necessarily coincide with public objectives. ${ }^{146}$ Although there is a long tradition of private antitrust suits following on public investigations and litigation-cases in which one might assume a degree of correspondence between public aims and private actions-very little contemporary private litigation falls into this category. ${ }^{147}$ Similarly, there is little evidence of follow-on litigation in our sample. The common types of private health care antitrust suits being brought (staff privileges and exclusive contracting) and the sectors in which they concentrate (physician-hospital relations) often fail to implicate important competitive or health policy concerns.

One would expect, however, the activities of the federal enforcement agencies (the DOJ and FTC) to serve the general welfare, at least as it is understood by the presidential administration in power. ${ }^{148}$ If medical antitrust law fails to exert beneficial effects on competition through private litigation, then does it do so through public enforcement? Public en-

146. Antitrust injury and standing doctrines are fluid, and courts have been flexible in their application to permit plaintiffs to bring suits that might raise legitimate claims. See, e.g., In re Brand Name Prescription Drugs Antitrust Litig., 123 F.3d at $604-06$ (invoking an exception to Illinois Brick's indirect purchaser bar where intermediate purchasers, wholesale middlemen, were also alleged conspirators); Rozema v. Marshfield Clinic, $977 \mathrm{~F}$. Supp. 1362, 1375 (W.D. Wis. 1997) (rejecting defendant's argument that "HMO subscribers [were] indirect purchasers of physician services" that were being "resold" through the HMO). Still, there have always been substantial difficulties empowering consumers who are in theory the preferred private antitrust plaintiffs. See, e.g., Askew v. DCH Reg'l Health Care Auth., 995 F.2d 1033, 1037-41 (11th Cir. 1993) (holding that defendant was a political subdivision and was immune under state action doctrine in light of Alabama statutes); Advocacy Org. for Patients \& Providers v. Mercy Health Servs., 987 F. Supp. 967, 970 (E.D. Mich. 1997) (denying plaintiffs' request for TRO to block defendants' hospital merger, finding little likelihood of plaintiffs' success on the merits).

147. Thomas E. Kauper \& Edward A. Snyder, Private Antitrust Cases That Follow on Government Cases, in Private Antitrust Litigation, supra note 15, at 329, 332 (reporting that less than $9 \%$ of the private cases in the Georgetown sample represented follow-on forms of private litigation). The $9 \%$ follow-on cases in the Georgetown sample contrasts with reports that nearly $75 \%$ of all private cases in the first half of the last century came in the wake of government prosecutions. Robert W. Stedman, Comment, Consent Decrees and the Private Action: An Antitrust Dilemma, 53 Cal. L. Rev. 627, 628 n.7 (1965).

148. In this Article, we adopt a relatively uncritical public interest theory of government enforcement. At this stage of our study, we are primarily interested in using the government cases as a foil against which to compare and contrast private enforcement efforts. The extent to which public antitrust enforcement actually furthers the public interest is an important and difficult question. In a subsequent phase of our study, we intend to focus more closely on government enforcement efforts and to examine more critically the social value of public antitrust activity in this area. 
forcement (including by state attorneys general) accounted for merely $6 \%$ of all litigated disputes in our survey-a small portion of the medical antitrust cases decided in federal courts. Nonetheless, these cases may have importance disproportionate to their numbers by halting especially harmful conduct, deterring misbehavior by other similarly situated parties, or aiding the productive evolution of the underlying substantive law. In addition, litigated cases represent only a fraction of the potentially anticompetitive activity investigated and addressed by the DOJ and the FTC using other enforcement tools. ${ }^{149}$ Settlements, advisory opinions, policy statements and the like may be more powerful influences on industry conduct than litigated cases. We must therefore explore two questions using our empirical findings. First, what is the impact of public enforcement actions on the federal courts? Second, how do litigated cases relate to other work performed by the enforcement agencies?

The small number of cases brought by the DOJ and the FTC does not necessarily indicate that antitrust law cannot promote competition in medical markets. Antitrust law can serve as an effective deterrent even without many prosecutions. For example, the Supreme Court's 1982 decision in Maricopa put the health care industry on notice that it was subject to the Sherman Act's per se rule against price fixing. The fact that DOJ and FTC consent orders involve price fixing and other per se conduct more often than do litigated cases provides support for this hypothesis. ${ }^{150}$ Furthermore, even though the DOJ has not pursued many crimi-

149. The 22 litigated disputes are the tip of a public enforcement iceberg, constituting $24 \%$ of the combined total of 89 agency enforcement actions during the study period. The 39 disputes resolved by FTC consent orders and administrative decisions and the 20 disputes resolved by DOJ consent degrees represent another layer of effort. Beneath both of these layers is the bulk of the agencies' work: cases investigated but not pursued, responses to business review letters and advisory opinions, as well as speeches by enforcement agency personnel to industry groups, comments on proposed legislation, and the production of industry specific guidelines. Between 1985 and 1999, the DOJ issued 60 business review letters in health care matters, and the FTC issued 73 advisory opinions.

150. Our data shed some light on the question of which public cases settle and which are litigated. As stated earlier, there are historic estimates that place the settlement rate for government antitrust enforcement efforts generally at 80\% from 1955-1973 and at 92\% from 1973-1981. McDavid et al., supra note 51, at 883. In our health care specific survey, $67 \%$ of DOJ cases and $78 \%$ of FTC cases settled. Assuming that the older numbers retain some contemporary significance, the rate of settlement in health care cases appears to be lower than in other antitrust cases. The hospital merger cases, which we argue elsewhere as being aberrational, drive some of these results. Defendant hospitals with concentration ratios that would be considered presumptively unlawful (and treated as such) in any other sector of the economy proceed to trial and have obtained a remarkable level of success in the district courts. The data further support the contention that government cases alleging per se illegal conduct are more likely to settle. None of the litigated cases involve cases against contracting intermediaries, such as IPAs and PPOs (likely facilitators of price fixing agreements), while 9 consent decrees $(13 \%)$ name such entities as defendants. Only 2 litigated cases involve conduct classified as joint contract negotiations $(9 \%)$, while such conduct is at issue in 17 consent decrees (25\%). Finally, price fixing was alleged in only one publicly litigated case (the criminal prosecutions in 
nal cases in health care-and even though the verdicts obtained in United States $v$. Alston were not upheld by the Ninth Circuit-the few prosecutions that have occurred received substantial publicity. While one must ask whether these signals are lost or muted because of the noise generated by substantially larger numbers of often meritless private lawsuits, the volume of private suits may actually exert a sentinel effect, furthering the general deterrent message in per se cases by keeping potential defendants vigilant regarding potential antitrust liability.

Still, our data suggest an unsettled relationship between courts and the enforcement agencies with respect to medical antitrust law, limiting the potential impact of public enforcement decisions on competition. Courts take cases brought by the DOJ and the FTC seriously and frequently side with those agencies against private parties. ${ }^{151}$ Occasionally, however (more than occasionally where hospital mergers are concerned), the courts disagree with public enforcement, which inevitably affects the power of the agencies to negotiate private settlements in similar situations as well as their decisions to litigate future cases. ${ }^{152}$ At one level, this accords well with the notion, familiar from recent antitrust literature, that the FTC and the DOJ may be more effective as regulators than as prosecutors, particularly in highly specialized industries such as health care. ${ }^{153}$ Under this theory, courts would play a backstop role, using judicial accountability to keep the agencies honest in their regulatory role. Other health care regulation is conducted similarly; for example, efforts by the Office of Inspector General (OIG) of the Department of Health and Human Services to root out fraud and abuse affecting the Medicare and Medicaid programs. ${ }^{154}$ This pattern is typical of the administrative law

United States $v$. Alston), whereas price fixing was alleged in $18(27 \%)$ of the cases producing consent decrees. A similar pattern exists for boycott claims.

151. While the government's approximately $50 \%$ win ratio in health care cases looks good in comparison with the extremely low rate of private plaintiff victories, it compares unfavorably with historic government antitrust win/loss ratios. See Priest \& Klein, supra note 45 , at 53 (reporting that historically DOJ and FTC won $81 \%$ of antitrust cases litigated) (calculation based on tables compiled by Posner, supra note 18, at 381 tbl.11). Antitrust is a relative newcomer to the professions in general and to health care in particular. The novelty of many of the claims may explain part of the lower rates of victory. Part of the explanation must also lie with the government's abysmal success rate in the hospital merger cases. Hospital mergers account for 9 of the 11 health care outcomes classified as defendant victories.

152. One would expect this effect to be more pronounced for the DOJ, which has no formal enforcement authority apart from judicial process, than for the FTC, which can bring cases through administrative adjudicatory mechanisms, subject to appellate level judicial review.

153. See Spencer Weber Waller, Prosecution by Regulation: The Changing Nature of Antitrust Enforcement, 77 Or. L. Rev. 1383, 1417-35 (1998). These arguments generally lead to the conclusion that a regulatory approach requires a less confrontational style and a greater expectation of a continuing relationship with the subject of one's investigation than is common among prosecutors.

154. A growing proportion of antifraud enforcement activity is conducted through settlements, "corporate integrity agreements," and other forms of self policing. When 
model of the post New Deal state, which views courts primarily as trustees of congressional intent, restraining agencies from misinterpreting or overstepping their mandates, rather than as lawmakers in their own right.

Indeed, the FTC and DOJ have behaved like regulators in recent years, sometimes following explicit congressional instructions but often acting on their own. In 1993, 1994, and 1996, the two agencies issued joint Policy Statements Regarding Antitrust Enforcement in the Health Care Industry. ${ }^{155}$ It is generally accepted that the 1993 policy statements were released in order to demonstrate the agencies' willingness to engage in dialogue with the health care industry, which was in the first throes of consolidation in response to managed care, and thereby to forestall legislative action as part of national health reform that might extend antitrust immunity to various constituencies and activities. ${ }^{156}$ Because they focus on a single industry, the policy statements are unique among guidance documents published by the federal enforcement agencies. ${ }^{157}$ In addi-

negotiations falter and OIG or DOJ must initiate formal judicial enforcement processes, the rules of the game change dramatically because courts often respond differently to the underlying facts and law. See generally Timothy Stoltzfus Jost \& Sharon L. Davies, The Empire Strikes Back: A Critique of the Backlash Against Fraud and Abuse Enforcement, 51 Ala. L. Rev. 239, 305-07 (1999) (discussing the settlement process for medical fraud claims and high risk borne by providers who elect to go to trial).

155. See Department of Justice and Federal Trade Commission Statements of Antitrust Enforcement Policy in Health Care, 4 Trade Reg. Rep. (CCH) I 13,153, at 20,799 (Aug. 5, 1996); Department of Justice and Federal Trade Commission Statements of Enforcement Policy and Analytical Principles Relating to Health Care and Antitrust, 4 Trade Reg. Rep. (CCH) II 13,152, at 20,769 (Sept. 30, 1994); Department of Justice and FTC Antitrust Enforcement Policy Statements in the Health Care Area, 4 Trade Reg. Rep. (CCH) I 13,151, at 20,755 (Sept. 15, 1993).

156. For this reason, the 1993 policy statements did not break new ground, but basically restated existing law in reader friendly prose, with examples. The 1994 and 1996 policy statements, by contrast, attempted in truer regulatory fashion to address cutting edge practices that had not yet been resolved by the courts. Agency "good citizenship" under threat of legislative curtailment of enforcement authority persists to this day. Former Representative Campbell continually introduced legislation into the House that would bave granted independent physicians the same right to collectively bargain that is enjoyed by labor unions. See, e.g., H.R. 1304, 106th Cong. (1999); H.R. 4277, 105th Cong. (1998). In 2000, the Campbell bill was passed by the House of Representatives but not brought to a Senate vote.

157. The enforcement agencies have issued guidelines on a number of different topics. Perhaps best known are the Horizontal Merger Guidelines, Department of Justice and Federal Trade Commission Horizontal Merger Guidelines, reprinted in 4 Trade Reg. Rep. (CCH) I 13,104, at 20,569 (issued Apr. 2, 1992, revised Apr. 8, 1997), but the agencies have also issued guidelines in the areas of intellectual property, Department of Justice and the Federal Trade Commission Antitrust Guidelines for the Licensing of Intellectual Property, reprinted in 4 Trade Reg. Rep. (CCH) 1 13,132, at 20,733 (Apr. 6, 1995), and international undertakings, Department of Justice and the Federal Trade Commission Antitrust Enforcement Guidelines for International Operations, 4 Trade Reg. Rep. (CCH) II 13,107, at 20,589 (Apr. 5, 1995). State attorneys general have also promulgated antitrust enforcement guidelines. See Vertical Restraints Guidelines, 49 Antitrust \& Trade Reg. Rep. (BNA) No. 1243, at 996 (Dec. 4, 1985); Horizontal Merger Guidelines, 52 Antitrust \& Trade Reg. Rep. (BNA) No. 1306, at S-1 (Mar. 12, 1987). 
tion to explaining the agencies' analytic approach to common fact patterns, the statements identify "safety zones" that will not attract scrutiny, and pledge the agencies to rapid turnaround of requests for pretransaction review. All of these features are more familiar to regulators than to prosecutors. ${ }^{158}$ Similarly, one can observe patterns of enforcement agencies using their authority to discourage specific practices they deem to be a threat to competition, such as "most favored nation" (MFN) clauses in certain insurance reimbursement contracts. ${ }^{159}$

However, there are two problems with a regulatory approach to antitrust enforcement. First, the federal antitrust laws, unlike the fraud laws, do not contain a detailed statutory scheme that can guide judicial interpretation. Instead, the Sherman Act's broad "restraint of trade" language envisions a strong role for the courts as developers of law. ${ }^{160}$ Second, because courts are preoccupied with often groundless private litigation, most health care antitrust decisions in our sample did not refine or advance the law, weakening the case for the courts guiding the public enforcement agencies. Again, the exception is the hospital merger cases, but it remains to be seen whether the defeats suffered by the FTC and the DOJ will help them refine their enforcement approach, rather than being regarded merely as "judicial nullification." Nonetheless, our data

158. In fraud enforcement, a good example is the issuance of advisory opinions regarding potential kickbacks, a practice long resisted by the DOJ as incompatible with prosecution of crime because it required the agency to divine the presence or absence of criminal intent. Only in the intense political climate of the mid-1990s did Congress finally require the Secretary of HHS to issue advisory opinions. See Health Insurance Portability and Accountability Act of 1996, 42 U.S.C. $\$ 1320$ a-7d (Supp. 1999).

159. All five entries under "unilateral imposition of contracts provisions" in the consent decree subset involved challenges by the DOJ to MFN provisions. See United States v. Med. Mut., 1999-1 Trade Cas. (CCH) I 72,465, at 84,264 (N.D. Ohio 1999) (nullifying Most Favored Rate requirement instituted by insurer in attempt to secure lowest rate that a hospital gave to any third party); United States v. Delta Dental of R.I., 1997-2 Trade Cas. (CCH) I 71,860, at 80,045 (D.R.I. 1997) (nullifying similar scheme instituted by dental insurer); United States v. Vision Serv. Plan, 1996-1 Trade Cas. (CCH) I 71,404, at 77,037 (D.D.C. 1996) (nullifying similar scheme instituted by vision insurer); United States v. Or. Dental Serv., 1995-2 Trade Cas. (CCH) I 71,062, at 75,045 (N.D. Cal. 1995) (nullifying similar scheme instituted by dental insurer); United States v. Delta Dental Plan of Az., 1995-1 Trade Cas. (CCH) I 71,048, at 74,962 (D. Az. 1995) (same).

160. Section 1 of the Sherman Act broadly prohibits contracts, combinations, and conspiracies in restraints of trade, 15 U.S.C. $\$ 1$ (1994), while section 2 prohibits monopolization and attempted monopolization. 1d. $\$ 2$. Judges have interpreted this language as extending to courts an organic mandate to develop a federal common law of antitrust. See Peter J. Hammer, Antitrust Beyond Competition: Market Failures, Total Welfare, and the Challenge of Intramarket Second-Best Tradeoffs, 98 Mich. L. Rev. 849, $906 \mathrm{n} .151$ (2000). Even the FTC Act, which is a mandate to an administrative agency rather than the courts, speaks at a high level of generality. Section 5 of the FTC Act broadly prohibits " $[u]$ nfair methods of competition." 15 U.S.C. $\S 45(\mathrm{a})$. To be fair, some health care fraud laws are also vague and overbroad. See, e.g., 42 U.S.C. $\$ 1320 \mathrm{a}-7 \mathrm{~b}$ (b) (2001) (prohibiting "remuneration" in exchange for referring Medicare or Medicaid patients); see also William M. Sage, Fraud and Abuse Law, 282 JAMA 1179, 1180 (1999) (describing large gray areas in federal fraud law). 
strongly suggest that meaningful oversight of competition in health care will depend in large part on evolving a more theoretically coherent relationship between the public enforcement agencies and the courts.

\section{B. How Do Antitrust Courts Approach Quality and Nonprice Competition?}

Turning to the centerpiece of our empirical investigation-nonprice competition in health care-we begin by restating our initial hypothesis: Antitrust courts are unlikely to examine quality concerns often and are not likely to address them very well. This is essentially a negative hypothesis and, as such, one that is difficult to establish persuasively. What evidence would tend to disprove our assertion? If we were to conclude that courts were adequately addressing quality concerns, we would expect to find evidence that courts first acknowledged the existence of quality related problems in medical antitrust cases, and then brought to bear appropriate theoretical and empirical understandings to help resolve those issues. We found little evidence of courts acknowledging quality concerns. We found almost no evidence of courts taking advantage of existing theoretical or empirical understandings of quality that might be drawn from fields such as the health services research literature. Finally, we found little evidence of courts devising useful heuristics to guide their analysis that could substitute for more formal models of nonprice competition. From these observations we conclude with a fair level of confidence that current courts applying existing doctrine are not adequately addressing quality concerns. ${ }^{161}$

No dominant pattern of judicial treatment of quality concerns emerges from the diverse collection of cases we reviewed, precluding any attempt to articulate a unified theory of health care quality under federal antitrust law. The lack of a unitary approach to health care quality competition is not surprising. As already noted, quality is a slippery concept. Even within medical science and health services research, quality is notoriously difficult to define, assess, or operationalize. Economics fares little better. Economic theories and models to predict the implications of market structure and competition for quality and other nonprice concerns are often indeterminate. This is true not only for health care quality, but for nonprice competition throughout the economy. ${ }^{162}$ Unless and until economists and health services researchers can produce simple predictive

161. The desire to prove a negative helps explain our commitment to comprehensively examining medical antitrust cases with a highly detailed coding instrument. After casting a fine-gauged net, trolling the entire sea of opinions over the past 15 years, and coming up largely empty, we believe we have demonstrated that not much quality related activity is taking place.

162. For a discussion of the lack of a cohesive economic approach to nonprice competition generally, not merely for health care, see supra note 25; see also Sage \& Hammer, Competition Policy, supra note 13, at 1078-88 (asserting that price does not constitute an accurate proxy for quality). 
models of the impact of competition on objectively verifiable dimensions of health care quality, courts will largely be feeling their way in the dark.

Significantly, in the absence of a cohesive theoretical framework, courts have not tried to impose their own views on quality as a matter of judicial fiat. ${ }^{163}$ Many quality concerns simply do not fit well within the frames of reference that antitrust disputes provide for the private litigants who contest the lion's share of cases, regardless of whether courts might be receptive to such arguments. On the plaintiff's side, harm to quality or restrictions on available price-quality combinations create fewer incentives to litigate, are less salient for triers of fact, and present much more speculative evidence of antitrust injury and damages, than issues of price and cost. ${ }^{164}$ Certainly, the few winning cases in our sample did not argue

163. Might sometimes makes right in law as elsewhere, but the voice of the highest U.S. court has seldom been heard directly where quality is concerned. Of the four Supreme Court opinions in our sample, two were staff privileges cases, one was a concerted refusal to provide documentation to insurers, and one involved self-regulatory restrictions on professional advertising. The last two cases did raise issues of quality, but the Court's opinions take opposite approaches to the problem. In FTC $v$. Indiana Federation of Dentists, a case decided in 1986, the Court basically assumed that markets would function well and produce appropriate price/quality tradeoffs. 476 U.S. 447, 459-62 (1986). Indiana Federation of Dentists can also be seen as a product of its time. The case involved professional resistance to early utilization review by third party payors. The Court sent a clear signal that provider efforts to resist the growth of managed care would not be treated kindly under antitrust law. In Califormia Dental Ass'n v. FTC, decided in 1999, the Court adopted a much more skeptical view of markets and their ability to safeguard quality in health care. 526 U.S. 756, 772 (1999). California Dental Ass' $n$ can be seen as a bellwether of the growing backlash against managed care. This opinion, however, comes at the chronological end of our sample, so its full effects on lower courts remain to be seen. Still, neither opinion stakes out a clear position on the nature of quality in health care or the relationship between quality and price.

Chronology is also significant as it bears on the relative importance of price and nonprice competition in health care. We chose as a starting date for our empirical sample the year 1985, when private employers and the insurers who served them were beginning to experiment with care management techniques in order to control persistent double digit increases in annual premiums, and shortly after Medicare had converted to a prospective payment policy for hospitals with the explicit goal of cost containment. Clark Havighurst has argued that the Goldfarb case broke down the most intractable obstacle to price competition in health care-professional immunity from antitrust enforcementand allowed managed care to flourish. Clark C. Havighurst, Health Care as a (Big) Business: The Antitrust Response, 26 J. Health Pol., Pol'y \& L. 905, 906-09 (2001). As described above, see supra note 11 and accompanying text, our focus in this Article on quality competition derives in part from our concern regarding price-quality tradeoffs after managed care unleashed vigorous price competition. Yet our sample, even in the later years, contains few managed care cases. Rather, it remains dominated by disputes over medical staff privileges and hospitals' exclusive contracting practices. Nor does our sample encompass many disputes involving pharmaceuticals, medical devices, or biotechnology, even though the cost of medical innovation has in recent years risen to the top of both public and private health reform agendas.

164. Quality claims are difficult to establish both as a conceptual and an evidentiary matter. In United States v. Mercy Health Services, 902 F. Supp. 968, 986-87 (N.D. Iowa 1995), vacated by 107 F.3d 632 (8th Cir. 1997), the government argued that the hospital merger would substantially reduce the level of quality and nonprice competition in the 
subtleties such as effects on quality, but offered clear proof of classic per se illegal, anticompetitive, monopolistic, or exclusionary behavior. ${ }^{165}$ On the defense side, articulating a rough quality rationale for challenged conduct may be useful in order to secure antitrust immunity under HCQIA, but it is far more difficult to establish quality affirmatively as a competitive parameter that can be measured and used to refute allegations of harm to consumers.

Even though no unified theory of quality competition emerges from the cases, one can identify distinct pockets of judicial activity regarding quality that document a number of interesting tendencies and beliefs. The remainder of this Section is devoted to exploring these themes.

1. The Unquestioned Orthodoxy: The Virtues of Competition. - How do courts view the relationship between competition and quality in health care? In the absence of affirmative theories about health care quality and its relation to competition, orthodox economic assumptions about the virtues of competition win substantially by default. What is interesting is not that unorthodox arguments are rejected, but that such arguments are seldom raised. The theoretical effects of competition on quality in health care markets are largely uncontested. This is surprising. Lack of price

market. The district court, either disingenuously or through a true misunderstanding of the nature of the claim, caricatured the government's position as a failure of the hospitals to remodel private rooms or to give away free child car seats to maternity patients. Id. at 987. The court proceeded to reject the government's arguments, citing the absence of hard evidence on likely adverse impacts on price or quality. Id.

From this perspective, it is interesting to note what has constituted acceptable evidence of quality in other cases. In FTC v. Butterworth Health Corp., 946 F. Supp. 1285, 1301 (W.D. Mich. 1996), the court relied upon its own impressions obtained from a personal tour of the defendant hospital facilities. While not providing much specific analysis, the judge was confident that he knew quality when he saw it. In HTI Health Services, Inc. v. Quorum Health Group, 960 F. Supp. 1104, 1140 (S.D. Miss. 1997), the court relied heavily on aspirational statements by physicians associated with the defendant hospitals that post-merger recruitment of specialists would decrease morbidity and mortality rates. "The Court was most impressed by the highly credible testimony of the physician witnesses who expressed a sincere intent that this merger provide a means for improving medical services and saving patients' lives." Id. at 1140. The Eleventh Circuit panel that reinstated the plaintiff's jury verdict in Key Enterprises of Delaware, Inc. v. Venice Hospital, 919 F.2d 1550, 1555, 1560 (11th Cir. 1990), reh'g en banc granted, 979 F.2d 806 (11th Cir. 1992), was persuaded by evidence that plaintiff lost substantial market share after defendant hospital's entry into the DME market, even though other evidence suggested that plaintiff's services were of a consistently higher quality than the defendant's.

Other litigants have not fared as well. In Flegel v. Christian Hospital, 4 F.3d 682, 688 (8th Cir. 1993), plaintiff submitted affidavits by osteopathic physicians (DOs) in general practice that the plaintiff, a DO urologist, provided higher quality care than did the competing MD urologists on staff at the defendant hospital. The court regarded these as insufficient to excuse the need to provide direct evidence of market power on the part of the defendant. In Kaczanowski v. Medical Ctr. Hospital, 612 F. Supp. 688, 695 (D. Vt. 1985), the court granted summary judgment to the defendant based upon its own conclusory assertions that sensitive medical equipment should not be entrusted to those "who fail to meet a high level of advanced medical training."

165. See supra notes $80-92$ and accompanying text. 
competition in health care markets can both produce monopoly rents and channel competitive forces into supplying products with more nonprice characteristics. ${ }^{166}$ However, economists scrupulously abstain from opining whether higher quality at a higher price is better or worse than lower quality at a lower price. Rather, they postulate that unfettered competition will yield the range of price-quality combinations that consumers want, and will therefore be "efficient" absent identifiable market failures. ${ }^{167}$ By contrast, there has always been much agonizing in health policy circles and among medical professionals about the degree to which health care is simply different from other products and services. This wringing of hands is often accompanied by loud laments over the "sacrifice" of quality to the bottom line (that is, price). Related protests are based on the supposedly adverse effects of competition on "professionalism," which encompasses values such as charity, compassion, and social harmony, as well as quality. ${ }^{168}$

Our data indicate that in most health care antitrust litigation, such "meta concerns" are rarely on the judicial radar screen. ${ }^{169}$ Of the opinions that expressed general beliefs about the role of competition, the vast majority adhered to traditional economic assumptions. Competition in health care markets is presumed to lower health care prices, reduce health care costs, and improve health care quality. ${ }^{170}$ Only a small number of courts articulated sentiments critical of, or inconsistent with, this orthodoxy. Discussions about whether health care markets are different in ways that should be accommodated within antitrust doctrine also were relatively rare, even though the Supreme Court's decision in Goldfarb $v$.

166. See Sage \& Hammer, Competition Policy, supra note 13, at 1072-73.

167. Indiana Federation of Dentists, 476 U.S. at $459-62$, is probably the best citation for this position, although other courts have asserted the same proposition with varying degrees of enthusiasm. See, e.g., Ambroze v. Aetna Health Plans, No. 95 CIV. 6631 (DLC), 1996 U.S. Dist. LEXIS 7274, at *21-*22 (S.D.N.Y. May 28, 1996), remanded by No. 967778, 1997 U.S. App. LEXIS 1048 (2d Cir. Jan. 24, 1997) (expressing faith in market's ability to strike appropriate price-quality tradeoffs); Koefoot v. Am. Coll. of Surgeons, 652 F. Supp. 882, 904 (N.D. Ill. 1986) (“[T]he 'best' product or service will be selected by consumers when their choice is made in an open market free of restraints.").

168. See, e.g., Jerome P. Kassirer, Managing Care-Should We Adopt a New Ethic?, 339 New Eng. J. Med. 397, 397-98 (1998) (arguing against corporatized medicine); Rice, supra note 10 , at 383, 387-96 (describing failures of market theory in health care system); Steffie Woolhandler \& David U. Himmelstein, Extreme Risk-The New Corporate Proposition for Physicians, 333 New Eng. J. Med. 1706, 1706-08 (1995) (criticizing market medicine); see also, e.g., Sherry Glied, Chronic Condition: Why Health Reform Fails 26-33 (I997) (describing "medicalist" opposition to market models).

169. See supra notes I05-I06 and accompanying text.

170. See, e.g., Swarthmore Radiation Oncology, Inc., v. Lapes, No. 92-3055, 1993 U.S. Dist. LEXIS 17035, at *8 (E.D. Pa. Nov. 15, 1993) ("If, as the plaintiffs allege, the defendants conspired to drive the Swarthmore center out of business, not only were the plaintiffs harmed, but so also were the health care consumers of the Delaware Valley. They were deprived of the benefits of competition-lower prices, higher quality, and greater choice."). 
Virginia State Bar provides a ready framework for such a debate. ${ }^{171}$ Goldfarb-era concerns that markets dominated by professionals might deserve special antitrust deference barely register in the published opinions. ${ }^{172}$ Courts are sometimes willing to acknowledge the issue, but are usually content to point to their mandate to apply the law as written and to advise dissatisfied litigants to take their arguments to the legislature. ${ }^{173}$

This is not to suggest that courts are incapable of incorporating quality concerns into a competitive framework. Quality can be thought of in competitive terms. The clearest examples come from the exclusive contracting cases, which constituted the second largest group of disputes in our sample. In the typical exclusive contracting case, a hospital that previously allowed any physician granted privileges by the hospital's self-governing medical staff to work in one of the hospital's departments decides to limit that department to a smaller group of physicians that enter into a contractual relationship with the hospital itself. ${ }^{174}$ Most often, these

171. 421 U.S. $773,780-92$ (1975).

172. An independent LEXIS search for cases meeting our final selection criteria that specifically cited footnote 17 of the Goldfarb opinion revealed only 10 such instances. This result tends to confirm our instrument's finding that Goldfarb-era concerns about the special nature of the professions have not substantially influenced contemporary health care antitrust analysis.

173. See, e.g., Patrick v. Burget, 486 U.S. 94, 105 (1988). There the Court said: [W] are not unmindful of the policy argument that respondents and their amici have advanced for reaching the opposite conclusion. They contend that effective peer review is essential to the provision of quality medical care and that any threat of antitrust liability will prevent physicians from participating openly and actively in peer-review proceedings. This argument, however, essentially challenges the wisdom of applying the antitrust laws to the sphere of medical care, and as such is properly directed to the legislative branch.

Id. This is not to say that Goldfarb plays no role in antitrust cases. Goldfarb is sometimes cited to justify application of the rule of reason rather than a per se standard of review for the conduct in question. See, e.g., Sherman Coll. of Straight Chiropractic v. Am. Chiropractic Ass'n, 654 F. Supp. 716, 722 (N.D. Ga. 1986) (declining to apply per se rule in part because "[p]rofessions are different in certain respects from commercial businesses"). This is somewhat ironic because other developments in the law of boycotts and vertical restraints probably allow the same result to be achieved without invoking deference to the learned professions.

174. In this process, the question of who chooses a particular physician and when such a choice is made is substantially altered. In traditional settings, patients selected their primary care physician, and that physician would select the hospital and often the provider of ancillary physician services, such as radiology or anesthesiology. Today, many patients select hospitals (or health plans) and the hospital (or plan) arranges additional services via exclusive contracts. Some physicians have challenged these practices under the antitrust laws, often for threatening the quality of care. These doctors maintain that patients benefit from having an expanded number of choices and that competition between individual physicians at the point of service improves quality.

Collins v. Associated Pathologists provides a useful illustration. 676 F. Supp. 1388, 1394-95 (C.D. Ill. 1987), aff'd, 844 F.2d 473 (7th Cir. 1988). Plaintiff pathologist challenged the hospitals' exclusive contract on the following theory:

[T] he exclusive agreements prevented patients at St. John's Hospital from having their pathology work done by anyone other than an APL [Associated Pathologists, 
cases involve physicians whose specialties, such as radiology, anesthesiology, pathology, emergency medicine, and invasive cardiology, are practiced in hospitals rather than private offices. In these instances, where the existence of the contract clearly signals a business transaction, courts have been receptive to the argument that the hospital is interested in improving its competitive position vis-à-vis other hospitals based on the quality of its affiliated physicians as well as the cost of supporting their practices. As the court in White $v$. Rockingham Radiologists, Ltd. observed:

Rockingham Memorial believes that by making one group responsible and accountable to it, rather than having fragmented responsibility and accountability, it minimizes its malpractice exposure, can better monitor operations and quality control, helps to insure that a qualified physician is nearby and available if needed, and promotes efficiency in scheduling and promptness in reading. ${ }^{175}$

The net effect of these benefits will be to increase the competitiveness of the hospital, and hence the level of quality in the market.

2. Challenging the Orthodoxy: Hospital Mergers. - An important exception to the economic orthodoxy can be found in the hospital merger cases. In these cases, antitrust courts occasionally veer toward heresy, ex-

Ltd.] doctor, and tbey prevented patbologists who were not APL members from offering his or her services to a patient at St. John's. The Plaintiff contends that the exclusive agreements had an adverse effect upon competition in the area of pathological services, because competition among pathologists would result in lower prices and/or increased quality of pathological work done for St. John's patients.

Id. The court rejected this argument, reasoning that the exclusive contract does not destroy competition:

In the present case, even though patients in St. John's Hospital do not have the choice of having doctors other than those from APL perform pathological work, they do have a choice prior to entering the hospital about which hospital they will enter, based upon factors such as price, quality, the type of services, and the staff members (including pathologists) of the hospitals in the relevant geographic market.

Id. at 1404-05. Other courts have argued that intensified physician competition over the exclusive contract itself improves quality and benefits patients. Balaklaw v. Lovell, 14 F.3d 793,799 (2d Cir. 1994). The rationale is that hospitals have better information and direct financial incentives to be efficient, and will make better choices than would individual patients selecting physicians ad hoc at the point of service.

175. 820 F.2d 98, 105 (4th Cir. 1987); see also Martin v. Mem'l Hosp., 130 F.3d I143, 1150 (5th Cir. 1997) (finding that exclusivity provides for standardization, uniformity, and quality control); Balaklaw, 14 F.3d at 799 (finding that competition for exclusive contracts increases quality); Todorov v. DCH Healthcare Auth., 921 F.2d 1438, 1457 (11th Cir. 1991) (finding that exclusivity permits centralization, increasing ability to monitor and control quality); Beard v. Parkview Hosp., 912 F.2d 138, 145 (6th Cir. 1990) (finding that exclusive contracting increases efficiency and quality); Steuer v. Nat'l Med. Enter., 672 F. Supp. 1489,1518 (D.S.C. 1987) (finding that exclusive contracting increases quality and monitoring), aff'd, 846 F.2d 70 (4th Cir. 1988); Mosby v. Am. Med. Int'l, Inc., 656 F. Supp. $601,606,609$ (S.D. Tex. 1987) (finding that exclusive contracting is procompetitive). The stamp of Justice O'Connor's concurring opinion in Jefferson Parish is clear in these cases. See supra note 89 . 
plicitly questioning the desirability of competition as a vehicle for determining the cost and quality of medical services. Expressing a willingness to trust the good intentions of the merging hospitals, these courts have blessed unions that would remain unconsummated in other industries. In FTC v. Butterworth Health Corp., for example, a federal district court denied a preliminary injunction and allowed the two largest hospitals in Grand Rapids, Michigan to merge based on their "white-hat" reputation, the support of community leaders, and their largely unenforceable promises (captured in a highly regulatory sounding judicial order) to act as benign monopolists. ${ }^{176}$ ln the same opinion, the court did little to hide its disdain for and distrust of the managed care organizations who lined up in opposition to the merger. ${ }^{177}$

An irony of the hospital merger cases is that judges have credited defendants' reputations for quality as support for allowing them to combine, thereby using arguments about quality to achieve the lessening of competition rather than its enhancement. For example, hospitals often successfully argue that premerger competition has resulted in a "medical arms race" with "unnecessary duplication" of services that has raised costs and prices for patients, and count the savings associated with consolidating services as an efficiency gain without offering any evidence that quality and access will not suffer. ${ }^{178}$ Litigation strategy partly explains the

176. 946 F. Supp. 1285, 1296 (W.D. Mich. 1996). In that case the court observed: Defendants argue the above findings demonstrate that nonprofit hospitals do not operate in the same manner as profit maximizing businesses. This is especially true, defendants contend, where as here, the boards of the merging hospitals are comprised of community business leaders who have a direct stake in maintaining high quality, low cost hospital services.

Id. Butterworth is not an isolated incident in this respect. A number of state attorneys general have approved hospital mergers after negotiating consent decrees similar to the one in Grand Rapids. See e.g., Wisconsin v. Kenosha Hosp., No. 96-G-1459, 1996 U.S. Dist. LEXIS 20215, at *5-*9 (E.D. Wis. Dec. 31, 1996) (consent decree permitting hospital merger on the belief that the merger would generate efficiencies, but requiring that portions of the cost savings be passed on to the community in the form of increased charity care or lower prices); Pennsylvania v. Capital Health Sys. Servs., No. 4:CV-95-2096, 1995 U.S. Dist. LEXIS 20268, at *6-*8 (M.D. Pa. Dec. 13, 1995) (state attorney general permitting merger conditioned, among other things, on the merged hospitals providing charity care); Pennsylvania v. Providence Health Sys., No. 4:CV-94-772, 1994 U.S. Dist. LEXIS 19849, at *6-*9 (M.D. Pa. May 24, 1994) (same).

177. Butterworth, $946 \mathrm{~F}$. Supp. at 1302 ("In the real world, hospitals are in the business of saving lives, and managed care organizations are in the business of saving dollars.").

178. See, e.g., FTC v. Freeman Hosp., 911 F. Supp. 1213, 1224 (W.D. Mo. 1995) ("After the consolidation, the new entity will be closer in size to St. John's, clearly the Joplin market leader, and will have equivalent resources and assets allowing it to offer comparable services."); United States v. Carilion Health Sys., 707 F. Supp. 840, 845 (W.D. Va. 1989) ("Roanoke Memorial needs more space in which to offer its obstetrics services and for various other clinical and administrative functions. On the other hand, Community's occupancy has declined faster than that of Roanoke's other hospitals. Community has extra space and needs more patients."). We do not want to overstate the case. A number of courts in the sample adopt more traditional views about the benefits of competition. These cases suggest that competition creates appropriate incentives to 
lack of attention to quality data. Not only are cost savings easier to estimate and more salient to courts, but most of the investment that merger defendants make in expert economic testimony tends to be directed to challenging the government's proposed product and geographic markets, upon which the determination of market power ultimately depends. This task is best accomplished by showing the existence of "noise" in the government's data, not by constructing precise models of the clinical services involved and their cost and quality implications. At the same time, courts have not been receptive to arguments by the federal enforcement agencies that merging hospitals may be able to exercise market power because their high quality puts them in a separate economic market for antitrust purposes. ${ }^{179}$

The hospital merger cases are provocative and present some of the most serious and successful challenges to traditional economic presumptions that can be found anywhere in contemporary antitrust law. ${ }^{180} \mathrm{Nev}-$ ertheless, a related and somewhat surprising finding of our study helps put the merger cases into perspective. As suggested above, the skeptical views courts express about the desirability or effectiveness of competition in hospital merger cases have not spread to other areas of medical antitrust litigation. Instead, these views remain largely contained in the merger domain. ${ }^{181}$ One explanation for the cabining of these sentiments

acquire and maintain state of the art technology. See, e.g., Howerton v. Grace Hosp., No. 4:90CV187, 1995 U.S. Dist. LEXIS 21123, at *22 (W.D.N.C. July 7, 1995) (“Since Blue Ridge Radiology opened its clinic in 1990, Grace Hospital . . finally purchased an up-todate ultrasound machine and made improvements in their mammographic images. These improvements at Grace Hospital were prompted mainly as a direct effect of competition from Blue Ridge's outpauient clinic."); see also, e.g., United States v. Rockford Mem'l Corp., 717 F. Supp. 1251, 1283 (N.D. Ill. 1989) (discussing beneficial effects of increased hospital competition), aff'd, 898 F.2d 1278 (7th Cir. 1990).

179. See United States v. Long Island Jewish Med. Ctr., 983 F. Supp. 121, 137-40 (E.D.N.Y. 1997) (rejecting government's "anchor hospital theory" that linked defendants' superior reputations and scope of services to local purchasing needs of managed care organizations, despite existence of other institutions within same geographic market).

180. See generally Peter J. Hammer, Questioning Traditional Antitrust Presumptions: Price and Nonprice Competition in Hospital Markets, 32 U. Mich. J.L. Reform 727, 729 (1999). There one of us said:

The economics of hospital mergers directly challenge core antitrust beliefs: the belief that competition will effectively allocate resources along price and nonprice dimensions, and the belief that competition will lower prices. The resolution of these issues will have implications for antitrust law that extend far beyond the health care field. Id.

181. Judicial assessment of exclusive contracting cases, for example, stands in sharp contrast to the bospital merger disputes. When we presented preliminary results of tbis study to a brown bag luncb of the DOJ/FTC Joint Health Care Taskforce, it was suggested by one official that there may be no tension at all between the merger cases and the exclusive contracting cases-the hospitals always win. This claim has descriptive merit. Nevertheless, the types of reasoning used and basic assumptions employed by the courts are quite different. The exclusive contracting cases sit comfortably within established doctrines of vertical nonprice restraints. The hospital is empowered to establish and 
is that, even within the health care system, only the hospital sector remains dominated by nonprofit institutions. ${ }^{182}$ Furthermore, charitable hospitals are usually protected by powerful political forces as a result of their long history, place in the community psyche, and status as large employers, often of unionized workers. The small, elite club of individuals from which hospitals draw their boards of trustees shares much with the privileged pool from which most federal district court judges emerge. Hospital merger cases may give some local judges the pleasure of telling a bunch of Washington based lawyers and bureaucrats spouting general theories of consumer protection how little they know about the institutions they are attacking. For whatever reason, the hospital merger cases are both significant in and of themselves and, paradoxically, largely aberrational.

3. Quality as "a Part of" or "Apart from" Competition. - Our findings of general beliefs consistent with economic orthodoxy and specific efforts to successfully incorporate quality concerns into a competitive analysis in the exclusive contract cases provide only weak support for the claim that quality improvements are understood by courts as a desirable outcome of health care competition. Certainly, some courts grasp the competitive dimensions of hospital quality standards such as physician qualifica-

enforce what it believes to be appropriate intra-firm price/quality standards, and inter-firm competition is trusted to yield appropriate market level price/quality tradeoffs. In contrast, the hospital merger cases fundamentally question the virtues of inter-firm competition in medical markets.

182. If one looks at antitrust law generally, one finds many nonprofit antitrust defendants on the losing end. See, e.g., NCAA v. Bd. of Regents, 468 U.S. 85, 120 (1984) (holding that NCAA restrictions on number and price of games member colleges could televise constituted illegal restraint of trade in violation of section 1 of the Sherman Act); Nat'l Soc'y of Prof'l Eng'rs v. United States, 435 U.S. 679 (1978) (holding that professional society's ban on competitive bidding was a violation of Sherman Act). Moreover, black letter antitrust law states that nonprofit institutions can be just as guilty of an antitrust violation as for profit entities. See NCAA, 468 U.S. at $100 \mathrm{n} .22$ ("There is no doubt that the sweeping language of $\$ 1$ applies to nonprofit entities, and in the past we have imposed antitrust liability on nonprofit entities which have engaged in anticompetitive conduct." (citations omitted)).

Even in the domain of hospital mergers, there have been dissenting voices refusing to afford nonprofit hospitals any particular deference. In one case, the Eleventh Circuit rejected a variety of alleged charity benefits attributable to the merger under review, holding that antitrust law compels the conclusion that the public interest is best served through competition. FTC v. Univ. Health, Inc., 938 F.2d 1206, 1225 (11th Cir. 1991). In Mercy Health Services, a court otherwise predisposed to view hospital mergers favorably rejected the hospitals' charity claim, reasoning that nothing within the board's structure ensured that the benefits would be realized. United States v. Mercy Health Servs., 902 F. Supp. 968, 989 (N.D. Iowa 1995), vacated by 107 F.3d 632 (8th Cir. 1997) (pointing out that, notwithstanding the good intentions of current board members, if there is potential for future board members to engage in illegal activity, then "there is nothing inherent in the structure of the corporate board or the non-profit status of the hospitals which would operate to stop any anticompetitive behavior"). 
tions. ${ }^{183}$ There is a strong sentiment in the case law that hospitals should have the authority to impose and enforce quality related standards, and that such standards will enhance competition in the market generally. ${ }^{184}$ Our data also suggest, however, that other courts segregate quality from their competitive analysis in antitrust disputes, addressing it as a separate matter. In fact, one of the most difficult challenges in applying the coding instrument to the cases was to distinguish judicial discussions of quality as a professional concern from discussions of quality as a competitive dimension. ${ }^{185}$ The coders' difficulties in discerning such distinctions in largely

183. Courts that understand the competitive dimensions of hospital standards consider selectivity a virtue, and are solicitous of hospital efforts to adopt and enforce strict physician qualifications. "Hospitals are not public utilities, required to grant staff privileges to anyone with a medical license. The Marshfield Clinic's reputation for high quality implies selectivity in the granting of staff privileges at hospitals affiliated with the Clinic." Blue Cross \& Blue Shield United of Wis. v. Marshfield Clinic, 65 F.3d 1406, 1413 (7th Cir. 1995). To this end, hospital quality controls and staff privileges decisions are viewed as procompetitive practices. "[H]ospitals must make choices about the types of qualifications a practitioner must have to apply for staff privileges in various fields of practice. . . . These restrictions help it provide more efficient, higher quality services in order to compete against other hospitals." Flegel v. Christian Hosp., Northeast-Northwest, 4 F.3d 682, 687 (8th Cir. 1993); see also Matthews v. Lancaster Gen. Hosp., 87 F.3d 624, 640 (3d Cir. 1996) ("Moreover, we believe peer review actions, when properly conducted, generally enhance competition and improve the quality of medical care."); Potters Med. Ctr. v. City Hosp. Ass'n, 800 F.2d 568, 576 (6th Cir. 1986) ("[T] he court held that a nonmonopolist hospital's policy of restricting staff appointments to very highly qualified applicants did not impose an unreasonable restraint on trade, because by building a high quality staff the hospital would improve its competitive posture, thereby increasing competition in the relevant market.").

184. See Bhan v. NME Hosps., Inc., 929 F.2d 1404, 1412 (9th Cir. 1991) (finding that hospitals need to be able to establish quality standards and qualifications and that these standards will ordinarily improve the hospital's efficiency and competitiveness); Nanavati v. Burdette Tomlin Mem'l Hosp., 857 F.2d 96, 121 n.24 (3d Cir. 1988) (finding that hospitals have legitimate rights under a rule of reason analysis to control the quality of their medical staffs); Flegel v. Christian Hosp. Northeast-Northwest, 804 F. Supp. 1165, 1172 (E.D. Mo. 1992) (noting that an assumption under rule of reason analysis is that restricting staff privileges to physicians with predetermined levels of competence will enhance a hospital's reputation and the quality of medical care it delivers), affd, 4 F.3d 682 (8th Cir. 1993); Husain v. Helene Fuld Med. Ctr., No. 89-2107 (AET), 1989 U.S. Dist. LEXIS 14738, at *10 (D.N.J. Dec. 8, 1989) (noting that hospitals have wide latitude to exclude physicians for their "lack of professional competence or their unprofessional conduct"); Kaczanowski v. Med. Ctr. Hosp. of Vt., 612 F. Supp. 688, 696 (D. Vt. 1985) (noting that hospitals are not passive providers of facilities, but rather play an integral part in the arrangement and provisions of medical services).

185. Blindness to the possible connection between medical quality and competitive processes runs deep in the law, and is not limited to antitrust cases. Some of it can be ascribed to the belief that quality is the exclusive province of individual health professionals, and is not a concern of corporate entities such as insurance companies. In Potvin v. Metropolitan Life Insurance Co., for example, the California Supreme Court ruled that a managed care organization acted improperly by terminating an obstetrician from its provider network without due process. 95 Cal. Rptr. 2d 496, 499, 506 (2000). Curiously, the purported reason for termination, that the physician had previously incurred malpractice claims against him, was viewed even by the dissenting justices as legitimate only to the extent that the defendant insurer might lower its costs because its physicians paid 
undifferentiated judicial assessments of quality underscore how much antitrust courts need to learn in order to appreciate the dimensions of quality and how they interact within a competitive system.

This problem is seen most clearly in the staff privileges cases, the largest pool of disputes in our sample. In a typical staff privileges case, a physician who desires to admit patients to a particular hospital or to perform specific medical procedures must demonstrate her legitimacy and competence by documenting matters such as her education, training, passage of relevant examinations, licensure, malpractice history, and experience at other institutions. Decisions regarding privileges are not made by the hospital itself, but by the hospital's self governing medical staff, a historically well established but conceptually obscure body consisting of the physicians currently allowed to practice at the hospital (virtually all of whom are independent economic entities), acting through their elected chief of staff and various committees. Courts struggle with quality in staff privileges cases for understandable reasons. First, most physicians comprising the medical staff conduct their business primarily in their offices or at other institutions, and have no clear economic interest in assuring the quality of physicians being considered for staff privileges. To the contrary, the economic interest of these physicians seemingly lies in excluding particularly high quality physicians, because they represent greater competitive threats. ${ }^{186}$ Second, and relatedly, HCQIA immunizes medical staff decisions from antitrust scrutiny to the extent that the decisions appear to be based exclusively and legitimately on quality, which reinforces courts' tendency to partition discussions of quality from discussions of competition when these disputes occur.

Overall then, our data show that courts can appreciate quality as a competitive concern, but not infrequently stray from that approach for reasons of either judicial temperament or historical path dependence. These tendencies and the resulting ambiguities they produce are nicely illustrated by the Supreme Court's 1999 decision in Califormia Dental Ass'n v. FTC, where the Court held that the competitive effects of a professional association's prohibitions on publicized price discounts and quality advertising must be evaluated using full blown rule of reason analysis, a decision that led the appellate court on remand to uphold those prohibitions. ${ }^{187}$ California Dental comes after two decades of Supreme Court

less for malpractice coverage. Id. at 513 (Brown, J., dissenting). Not only does this reflect ignorance of the market for professional liability insurance (physician policies are not experience rated), but the obvious point that a doctor who had been sued frequently might not be attractive to the insurer's customers completely eluded the court.

186. See, e.g., Patrick v. Burget, 486 U.S. 94, 95-97 (1988) (considering case of a new surgeon in town who had acquired a sufficiently good reputation to practice in competition with established group accused of poor care and investigated in an attempt to revoke his hospital privileges).

187. 224 F.3d 942, 943 (9th Cir. 2000). One should be cautious of inferring too much from the Ninth Circuit's reversal of the FTC decision. On remand, the FTC was hamstrung by a record that was intentionally short on expert testimony and direct economic evidence 
opinions in medical antitrust cases that consistently marginalized Goldfarb-type concerns. By reviving Goldfarb's provocative dictum in footnote 17 , the case arguably signals a renewed willingness of courts to fashion a unique set of antitrust rules tailored to medical markets, and might even presage a new era of judicial skepticism about the effects of competition in health care. On the other hand, the Court framed the conduct at issue in economic, not professional terms. The Court's reasoning was clearly predicated upon the existence of market failure (specifically, imperfect information) and the Court remanded the case for consideration of the "not implausible" procompetitive effects of the advertising restrictions at issue. From this perspective, California Dental can be reconciled with our finding that courts apply a traditional economic framework to health care disputes, and can even be read as an instruction to lower courts that quality in health care should be evaluated within, not apart from, the competitive paradigm.

4. Quality as a Component of Individual Firms or as an Attribute of Systems. - Our coding instrument was designed to detect a broad range of approaches antitrust courts might adopt when presented with disputes involving health care quality. As described above, we tried to envision how different disciplines might conceive of quality and give each view fair representation in the instrument. ${ }^{188}$ We divided these perspectives into "firm-level" and "system- or market-level" characteristics. The firm-level characteristics, consisting of twenty-five categories such as considerations of clinical and administrative structure and clinical process, tended to track the health services research literature. The market-level characteristics, consisting of ten categories such as freedom of choice, level of product differentiation, and the potential for technological or organizational innovation, tended to track the concerns of economists and antitrust lawyers.

The absolute number of codes in each category are roughly comparable. The total number of codes for firm-level characteristics (231) slightly exceeds the number of codes for market-level characteristics (212). ${ }^{189}$ If one looks at the total number of opinions coding at least one quality characteristic, however, one gets a slightly different result (134 separate opinions containing at least one market-level characteristic versus 122 opinions containing at least one firm-level quality characteristic). Similarly, if one focuses upon specific and not general coded characteris-

of anticompetitive effects because the case was designed to test tbe boundaries of quicklook rule of reason analysis. Id. at 959. How the FTC would fare on a record intended for full rule of reason review remains to be seen, altbough the additional administrative burden facing the enforcement agencies, courts, and private plaintiffs if such review is universally required will be great.

188. See supra text accompanying notes 25-37.

189. This was the case notwithstanding the fact that a mucb larger number of codes were available for firm-specific entries (25) than for market-level characteristics (10). 
tics, codes for specific market-level characteristics come out ahead with 172 codes versus 164 codes for specific firm-level entries.

What is to be made of this? Our impression from reviewing the text of these cases is that it is easier for courts to view the competitive dimensions of quality as a market-level, rather than as a firm-level, characteristic. On the one hand, a relative bias in favor of market-level characteristics may simply be reflective of a broader tendency in antitrust law and economics to treat the firm as a "black box." Apart from "transaction cost economics" and focused work by Coase and others on the theory of the firm, mainstream microeconomics and even most theories of industrial organization tend to treat the firm as an undifferentiated entity, or simply as a production function. ${ }^{190}$ Perhaps it is easier for courts to make analytic connections between quality and competition when they are already contemplating the market as the appropriate metric for analysis. On the other hand, courts may conceptualize health care as "systematized" for reasons having nothing to do with market economics. As Jim Blumstein has observed, the term "health care system" is unique, the "system" modifier seldom being applied to goods or services in other industries (for example, a "supermarket system" or an "automobile system"). ${ }^{191}$

These readings have opposite implications for the strength of antitrust law in overseeing health care competition. Courts that focus on the overall competitive landscape rather than the business prospects of specific litigants may be better equipped to impose doctrinal requirements such as antitrust injury, which requires cognizable harm to competition (not merely to individual competitors). However, courts that expect health care to function as a "system" in the Blumstein sense may be more tolerant of collusive professional activities and more dependent on anticompetitive restrictions to achieve redistributive goals than would be the case for other industries.

5. Quality as an Abstract Notion or as a Specific Characteristic. - Our results further indicate that judicial discussions of quality often occur at an abstract rather than a specific level. General or wastebasket categories

190. See, e.g., Joseph E. Stiglitz, Symposium on Organizations and Economics, $5 \mathrm{~J}$. Econ. Persp. 15, 15 (1991) ("Many economists argued that there was no need to look carefully into the black box called the firm: ... if managers didn't [maximize profits], they would be replaced; and firms that didn't maximize value wouldn't survive.").

191. James F. Blumstein, The Application of Antitrust Doctrine to the Healthcare Industry: The Interweaving of Empirical and Normative Issues, 31 Ind. L. Rev. 91, 94-95 (1998). Blumstein writes:

Application of the antitrust laws to the healthcare arena makes it clear that ... healthcare is an "industry" to be policed ... as are other economic sectors....

...

Cooperation and coordination were seen as socially appropriate tools for rationalizing a "system" ... . From an antitrust perspective, however, such conduct between or among competitors is far from the wholesome activity envisioned by its health planning proponents.

1d. 
such as "Unspecified process/outcome quality concerns," "General reputation for quality," and "Unspecified quality of patient care" accounted for $25 \%$ of the quality related entries. A similar picture is revealed by looking at opinions instead of coded entries. Recalling that there were a total of 194 opinions containing quality codes, a total of 74 opinions ( $38 \%$ of all opinions with quality codes) contained one or more of the "general" quality codes. In 22 opinions $(11 \%)$, general quality codes were the only codes to register.

Part of this tendency may be attributed to lack of precision in the coding instrument, but we believe that it also reflects a deeper reality about the dearth of meaningful ways to frame quality in antitrust litigation. First, as noted, there is little clear theory about quality and nonprice concerns in the economic and antitrust literature. 1t is therefore not surprising that courts tend to address quality concerns, if at all, in a fairly abstract manner. ${ }^{192}$ Second, courts often insist on quantitative economic evidence in antitrust litigation, such as sales volume, customer flows, market concentration, price, costs, revenues, and the like. ${ }^{193}$ By contrast, quality seems, well, qualitative, and courts tend to deal with it accordingly. Even relatively well established metrics for health care quality, such as HEDIS scores and other comparative "report card" tools designed specifically for consumer use, did not register with courts in our sample. ${ }^{194}$

Our results support a hypothesis advanced by Tom Kauper that the only dimensions of health care "quality" likely to find their way into antitrust litigation would be those that could be cast in a manner that directly indicates their economic significance. ${ }^{195}$ Kauper proposed two candidates: first, quality as it relates to malpractice liability exposure, and second, quality as it relates to the building of a provider's reputation and goodwill. ${ }^{196}$ Among firm-specific characteristics, "malpractice history" and the question of liability exposure registered 25 entries, while discussions of "general reputation for quality" registered 24 entries. These combined numbers reflect $11 \%$ of the total quality discussions and $22 \%$ of the firm-specific quality discussions. These aspects of health care qual-

192. E.g., United States v. Carilion Health Sys., 707 F. Supp. 840, 846 (W.D. Va. 1989) (speculating on quality gains from hospital merger); Cooper v. Forsyth County Hosp. Auth., 604 F. Supp. 685, 687 (M.D.N.C. 1985) (considering quality in connection with limitation of staff privileges to physicians).

193. E.g., United States v. Mercy Health Servs., 902 F. Supp. 968, 987 (N.D. Iowa 1995) (rejecting government's claim of reduced nonprice competition and demanding quantitative evidence of postmerger prices).

194. See supra text accompanying notes 32-34. Because HEDIS scores did not come into routine use until after 1995 , one must qualify this statement to take into account the years we studied and the inevitable delays that occur in litigation. It will be interesting to see whether future antitrust opinions make more liberal use of these "quantitative" quality measurement tools.

I95. Kauper, supra note 25, at 292-96.

196. Id. at 302-06. 
ity are relatively easy to advance and assess within antitrust law's dominant economic orientation. ${ }^{197}$

While our data suggest that economic, market-level conceptualizations of quality dominate the understandings of quality common in the health services research literature, courts that utilize firm-specific criteria take clinical structure into account far more often than clinical process or outcomes. Rankings in quality surveys, outcome statistics, preventative services, product defects, and the potential for clinical innovation or improvement fail to register using our coding instrument. To address the possibility that these issues are, in fact, the subject of motion practice or trial testimony, but do not make their way into published opinions, we presented our initial findings at a health care antitrust conference attended by leading members of the private bar. ${ }^{198}$ Several lawyers indicated that these issues are simply not being litigated.

Health services research concerns pertaining to aspects of clinical structure, on the other hand, do register in our data. On a firm-specific level, courts discussed the effects of competition on individual physician qualifications (29 entries), the adequacy of nonphysician staffing (11 entries), continuity of care (11 entries), the adequacy of physical facilities (10 entries), private accreditation (9 entries), the adoption and dissemination of advanced technology (8 entries), and government certification or licensing ( 3 entries). The bias in favor of structural concerns is not surprising because such characteristics are easier to detect and verify. This again highlights the importance of developing objective, reliable measures of quality as well as simple, predictive theories about the relationship between such characteristics and observable dimensions of competition if courts are effectively to address firm-specific quality in health care.

6. Choice and Information as Dimensions of Quality. - Courts consistently consider the degree of choice available in the market as an important aspect of quality that antitrust laws are designed to protect. In our sample, 95 opinions (18\%) discussed consumer choice, accounting for approximately half of all the market-level quality entries. Choice is a consideration that is easy for economists and antitrust lawyers to understand.

197. Closer textual examination of these cases reveals some of the problems discussed earlier. See supra text accompanying notes 183-187. While a number of cases clearly discuss medical malpractice as a competitive factor, many other courts tend to speak of malpractice issues more as a professional, rather than a competitive, concern. These courts do not make the economic translation suggested by Kauper. Other factors may also explain the high number of codes in these categories. For example, the finding may reflect the fact that antitrust courts remain more familiar with physicians and hospitals than they are with insurance organizations, and have not yet evolved a sophisticated understanding of purchasing decisions in the employment based health care system that prevails in the United States.

198. William M. Sage and Peter J. Hammer, Antitrust, Quality and the Courts, Presented at the Sixth Annual Health Care Antitrust Forum (Nov. 2000) (on file with the Columbia Law Review). 
Because free, rational (and informed) consumer choice is the engine that drives the competitive market, antitrust courts have been quick to condemn professional practices that seek to deny or interfere with individual health care choices.

Well functioning markets respond to different consumer preferences by providing a range of tailored products or services. Actions by entrenched market participants that artificially restrict the range of market alternatives available are inherently suspect from an antitrust perspective. ${ }^{199}$ A similar choice-related heuristic is that market entry of a new provider will be viewed as procompetitive. ${ }^{200}$ Consumer choice in antitrust law functions at a market, not an individual, level..$^{201}$ Consequently, courts are skeptical of plaintiff efforts to prove a limitation on consumer choice, and hence a cognizable antitrust injury, as a result of their own personal exclusion from the market. ${ }^{202}$ However, courts may condemn the exclusion of an individual provider who lays claim to a different man-

199. See, e.g., Reazin v. Blue Cross \& Blue Shield of Kan., Inc., 899 F.2d 951, 966 (10th Cir. 1990) (affirming jury finding based on expert testimony that Blue Cross' activities "would, in the long run, harm consumers because they would slow down or inhibit the development of alternative delivery systems, thereby reducing the options available to consumers"); Swarthmore Radiation Oncology, 1nc. v. Lapes, No. 92-3055, 1993 U.S. Dist. LEX1S 17035, at *8 (E.D. Pa. Nov. 15, 1993) (deciding that, if true, plaintiff's allegations show defendants conspired to lessen competition, depriving consumers of lower prices, higher quality, and greater choice); Sweeney v. Athens Reg'1 Med. Ctr., 709 F. Supp. 1563, 1573-74 (M.D. Ga. 1989) (upholding claim of nurse midwife who owned her own home birthing business, on the grounds that home birth was a valuable option to consumers, against hospital and $\mathrm{Ob} / \mathrm{Gyn}$ physicians for refusal to allow her access to patients).

200. See, e.g., Bio-Med Applications Mgmt. Co. v. Dallas Nephrology Assocs., No. 4:94cv37, 1995 U.S. Dist. LEX1S 20179, at ${ }^{*} 17$ (E.D. Tex. Feb. 7, 1995) (noting that defendant's opening of new dialysis clinics increased competition and provided more choice for patients); Advanced Health-Care Servs. v. Giles Mem'l Hosp., 846 F. Supp. 488, 496 (W.D. Va. 1994) (concluding that defendant hospital's entry into the durable medical equipment market increased competition and provided greater choice for customers); Howerton v. Grace Hosp., Inc., No. 4:90cv187, 1993 U.S. Dist. LEXIS 21042, at *61-*62 (W.D.N.C. Sept. 13, 1993) (granting defendant hospital summary judgment as plaintiffs "presented no plausible evidence that competition in this outpatient market has been adversely affected" by exclusive contract, which provides an alternative supplier of outpatient services to the market).

201. HTI Health Servs. v. Quorum Health Group, Inc., 960 F. Supp. 1104, 1135 (S.D Miss. 1997) (reasoning that because antitrust law does not assume perfect choices for each consumer, plaintiff hospital's harm alone should not be the proper plane of analysis and that "the proper focus must be on proof of harm to the market as a whole").

202. See Betkerur v. Aultman Hosp. Ass'n, 78 F.3d 1079, 1091 (6th Cir. 1996) (rejecting plaintiff's argument that defendant's boycott deprived patients' choice of a preferred supplier of neonatal care); Korshin v. Benedictine Hosp., 34 F. Supp. 2d 133, 138 (N.D.N.Y. 1999) (concluding that removal of individual provider from hospital did not broadly affect market choice but merely reshuffled competitors); Addis v. Holy Cross Health Sys. Corp., No. 3:94 cv 118 AS, 1995 U.S. Dist. LEX1S 21838, at*25-*26 (N.D. Ind. July 6,1995 ) (holding that plaintiff physician was not driven from market and that new surgeons provided consumers with "more choice and more competition"); Robles v. Humana Hosp. Cartersville, 785 F. Supp. 989, 998 (N.D. Ga. 1992) (denying standing in 
ner of practice, or who provides an option that may not otherwise exist in the market. ${ }^{203}$

Antitrust courts are also sensitive to informational market failures, arguably because notions of "free choice" are hard to reconcile with the dependence and asymmetric information inherent in the physician-patient relationship. ${ }^{204}$ Our survey revealed 17 instances in which courts discussed helping consumers make more informed choices. With notable exceptions such as Califormia Dental, courts tend to strike down restraints that artificially restrict the availability of information in the market. ${ }^{205}$ Courts also tend to encourage mechanisms that supply consumers with additional information, even if such information is the product of an agreement between actors who are otherwise competitors. ${ }^{206}$

Consumer choice is also a central theme in cases brought (and won) by the federal antitrust enforcement agencies, as well as in the consent

part because number of $\mathrm{Ob} / \mathrm{Gyns}$ in county had increased, providing consumers more choice and competition).

203. In Allen v. Washington Hosp., No. 96-1950, 1997 U.S. Dist. LEXIS 14606, at *17, *24 (W.D. Pa. May 30, 1997), plaintiffs alleged that defendants' conduct harmed patients by denying them access to emergency or weekend cardiology care, high quality care, diagnostic procedures, and second opinions, and the district court denied defendants' 12(b) (6) motion to dismiss as premature. See also Boczar v. Manatee Hosps. \& Health Sys., lnc., 993 F.2d 1514, 1517, 1519 (11 th Cir. 1993) (reversing and reinstating jury verdict for plaintiff in staff privileges case based on evidence that she provided different style of medicine than her competitors, consisting of lower-cost services and fewer caesarean sections); Loiterman v. Antani, No. 90 C 0983, 1991 U.S. Dist. LEXIS 8530, *11-*12 (N.D. Ill. June 23, 1991) (denying defendants' motion for summary judgment in staff privileges case where plaintiff argued that his termination prevented patients from obtaining less invasive, less costly surgical procedures and alternative methods of treatment). Not all plaintiffs making claims of alternative practice styles are successful. See Addis, 1995 U.S. Dist. LEXIS 21838, at $* 27$ (granting summary judgment for defendant and rejecting argument that plaintiff's creative use of laser surgery drew patients away from other physicians and was the motivation for conspiracy against him).

204. California Dental Ass'n v. FTC, 526 U.S. 756, 771-78 (1999), provides a recent, high profile discussion of information market failure. Lower courts are also sensitive to these concerns. See, e.g., Born v. Iannacone, No. 97-5607, 1998 U.S. Dist. LEXIS 15497, *14 (E.D. Pa. Sep. 28, 1998) (acknowledging existence of market failures in health care and particularly the effects of imperfect information on consumer decisionmaking). The difficulty that hospitalized patients face selecting suppliers of medical products is paradigmatic. See Key Enters. of Del., Inc. v. Venice Hosp., 919 F.2d 1550, 1557 (11 th Cir. 1990), reh'g en banc granted, 979 F.2d 806, 807 (11th Cir. 1992) (noting that choice of durable medical equipment provider is very easy to manipulate because hospital patients are captive and uninformed audience and are vulnerable to suggestions of hospital personnel).

205. See, e.g., FTC v. Ind. Fed'n of Dentists, 476 U.S. 447, 457, 460-62 (1986) (holding that withholding information or making its acquisition more expensive has inherently anticompetitive effects, obviating the need to prove market power, or even that the information was in fact useful to consumers).

206. See, c.g., Machovec v. Council for the Nat'l Register of Health Serv. Providers in Psychology, lnc., 616 F. Supp. 258, 272 (E.D. Va. 1985) (granting summary judgment in case involving psychologist who refused listing on national register on grounds that the registry provided the market with information and therefore had procompetitive benefits). 
decrees they enter into. In particular, the FTC's Bureau of Competition has concentrated its efforts in this area, perhaps because it accords well with other aspects of the agency's mission, such as the work of the Bureau of Consumer Protection. California Dental was a critical test of these theories, involving as it did both the FTC as plaintiff and professional restrictions on advertising as the subject matter. Standing alone, the Supreme Court's opinion upholding these restrictions may be taken either as renewed deference to professional self-regulation or merely as demanding more rigorous economic analysis of informational market failures. Considering the case in the context of our finding that lower federal courts tend to adopt an economic framework for assessing information, we are guardedly optimistic that the latter interpretation will prevail.

These patterns of judicial interpretation have important implications for the relationship between choice and other forms of quality competition. First, the exclusive dealing cases hammer a final nail into the coffin of "guild free-choice," 207 organized medicine's longstanding claim that all restrictions on patients' ability to consult physicians of their choosing-whether imposed by private insurers or by government-impair quality. Courts do not treat medical choice as any more sacred than choice in other industries, and they generally presume that adequate choice can exist even when customers are precluded from choosing the plaintiff. Second, courts have become sufficiently sensitive to choicebased arguments that physicians and hospitals may find them receptive to such claims in markets dominated by a small number of insurers with highly restrictive provider panels. However, what is sauce for the goose is also sauce for the gander, allowing managed care organizations to argue in opposition that consumers require choice among types of health care financing as well as among physicians or hospitals. Third, courts' greater familiarity with choice than with vertical metrics of quality may increase their skepticism regarding physicians' attempts to discourage service provision by supposedly "lower quality" professionals such as nurse practitioners, and may ultimately lead regulators to relax licensing and reimbursement standards limiting scope of practice for those groups. ${ }^{208}$

7. Innovation and Quality. - In large part because the discovery and dissemination of new drugs, medical devices, and diagnostic and therapeutic technologies determine future national health expenditures, the causes, costs, and benefits of innovation are becoming dominant issues in health policy circles. ${ }^{209}$ While choice plays a significant role in antitrust

207. See Charles D. Weller, "Free Choice" as a Restraint of Trade in American Health Care Delivery and Insurance, 69 Iowa L. Rev. 1351, 1367-72 (1984) (identifying anticompetitive effects of AMA's "ethical" condemnation of limitations on choice of physician).

208. See generally William M. Sage \& Linda H. Aiken, Regulating Interdisciplinary Practice, in Regulation of the Healthcare Professions 71, 71 (Timothy S. Jost ed., 1997) (describing legal and extralegal barriers to nonphysician practice).

209. See generally The Value of Innovation, Health Aff., Sept./Oct. 2001, at 10-60 (special section of issue devoted to innovation). 
analysis, courts have been less successful in incorporating innovation concerns into their evaluations. Innovation sits at the intersection of antitrust law and patent law. ${ }^{210}$ More often than not, courts have viewed the impact of antitrust doctrine simplistically, as apart from and opposed to the influence of patent law. ${ }^{211}$ Few courts have considered innovation as a factor in competitive analysis, although recent scholarship spawned by the Microsoft litigation has started to make headway in this direction. ${ }^{212}$

Our survey confirms that health care disputes follow the conventional wisdom. In what can be seen as an important negative finding, few medical antitrust courts address technological or organizational innovation as independent factors in their legal analysis. In the set of 542 judicial opinions we studied, there were only 7 coded entries for technological or organizational innovation as a system wide or market-level concern and only 6 coded entries for the potential for clinical innovation as a firm-specific consideration. Significantly, however, concern about innovation appears to influence the DOJ and FTC enforcement activities to a much greater degree. Technological or organizational innovation was

210. See, e.g., Louis Kaplow, The Patent-Antitrust Intersection: A Reappraisal, 97 Harv. L. Rev. 1815, 1823-29 (1984) (noting inherent conflict between patent and antitrust law and arguing that longer patent life encourages innovation at expense of "monopoly loss" incurred by society); Robert P. Merges \& Richard R. Nelson, On the Complex Economics of Patent Scope, 90 Colum. L. Rev. 839, 891-93 (1990) (noting that patents too broad in scope will diminish incentives for others to compete and will therefore hinder technological progress).

211. The court's reasoning in Boston Scientific Corp. v. Schneider (Eur.) AG is typical: "Indeed, the intersection of antitrust law and patent law is inherently complex because the two areas of law seek contradictory ends. 'The patent is itself a government grant of a monopoly and is therefore an exception to usual antitrust rules.' "983 F. Supp. 245, 269 (D. Mass. 1997) (quoting 3 Philip Areeda \& Donald Turner, Antitrust Law II 704-07, at 117-45 (1978)). There is a corresponding fear that strict antitrust enforcement could chill future innovation. See, e.g., C.R. Bard, Inc. v. M3 Sys., Inc., 157 F.3d 1340, 1372 (Fed. Cir. 1998) ("As a sister circuit recently stated, 'Antitrust scholars have long recognized the undesirability of having courts oversee product design, and any dampening of technological innovation would he at cross-purposes with antitrust law." (quoting United States v. Microsoft Corp., 147 F.3d 935, 948 (D.C. Cir. 1998))).

212. See, e.g., David McGowan, Innovation, Uncertainty, and Stability in Antitrust Law, 16 Berkeley Tech. L.J. 729, 776-811 (2001) (outlining recommendations for incorporating innovation into antitrust law); Maureen A. O'Rourke, Striking a Delicate Balance: Intellectual Property, Antitrust, Contract, and Standardization in the Computer Industry, 12 Harv. J.L. \& Tech. 1, 25-40 (1998) (proposing a research agenda to coordinate antitrust law with innovation); Arti K. Rai, Fostering Cumulative Innovation in the Biopharmaceutical Industry: The Role of Patents and Antitrust, 16 Berkeley Tech. L.J. 813, 844-53 (2001) (discussing improvements in antitrust law that would make it compatible with biomedical innovation); David S. Evans \& Richard Schmalensee, Some Economic Aspects of Antitrust Analysis in Dynamically Competitive Industries, 18-37 (Nat'l Bureau of Econ. Research, Working Paper No. 8268, May 2001) (discussing challenges that dynamically competitive markets pose for market definition and theories of predation). 
mentioned in 10 of the 82 settlements and administrative actions we coded involving the federal enforcement agencies. ${ }^{213}$

If one examines cases where pharmaceutical or medical device companies appear either as plaintiffs or defendants, what can be said about judicial treatment of innovation? As suggested above, innovation is seldom recognized as an independent antitrust issue even in this subset of cases (only 2 of the 7 coded entries were in opinions involving pharmaceutical companies). This does not mean that innovation concerns were not raised in these disputes. Rather, the tradeoffs between "competition" and "innovation" appear to be resolved by defining the domain of antitrust law to exclude disputes classified as patent or regulatory. The clearest examples of this phenomenon are disputes between competitors over patent and intellectual property rights, ${ }^{214}$ disputes between pharmaceutical manufacturers (often including generic drug manufacturers) over conduct pertaining to the Drug Price Competition and Patent Term Restoration Act of 1984 (the Hatch-Waxman Act), ${ }^{215}$ and cases challenging proceedings before the International Trade Commission (ITC) as furthering anticompetitive purposes. ${ }^{216}$

213. Moreover, our sample does not capture chronologically recent enforcement agency activity in the area of generic drug approval. The FTC has challenged the legality of patent settlements between brand name and potential generic manufacturers of specific drugs on antitrust grounds for allegedly delaying the entry of generics into the market. These investigations have resulted in two consent orders. See 1 n re Hoechst Marion Roussel, Inc., No. 9293, 200I FTC LEXIS 56 (2001); In re Abbott Laboratories, No. C-3945, 2000 FTC LEXIS 65 (2000). The FTC has also embarked on a broader study to assess the competitive effects of the Hatch-Waxman Act on the approval and marketing of generic drugs. See Agency Information Collection Activities; Proposed Collection; Comment Request, 65 Fed. Reg. 6I,334-36 (Oct. 17, 2000).

214. See, e.g., C.R. Bard, Inc., 157 F.3d at 1369 (raising claim of antitrust violation in patent dispute over a needle biopsy gun); Cygnus Therapeutics Sys. v. Alza Corp., 92 F.3d 1153, 1160-62 (Fed. Cir. 1996) (raising antitrust issues in patent dispute between producers of transdermal delivery devices); Mitek Surgical Prods., Inc. v. Arthrex, Inc., 21 F. Supp. 2d 1309, 1317 (D. Utah 1998) (raising antitrust issues in patent dispute between manufacturers of suture anchors); Boston Scientific Corp., 983 F. Supp. at 267-73 (raising antitrust issues in patent dispute between manufacturers of medical devices to treat clogged coronary arteries); Nobelpharma AB v. Implant Innovations, Inc., 930 F. Supp. 1241, 1250-54 (N.D. Ill. 1996) (raising antitrust issues in patent dispute between manufacturers of dental implants).

215. Pub. L. No. 98-417, 98 Stat. I585, 1585-1605 (1984). For a discussion of the effects of the statute and the complex interrelations between patent law and drug regulation, see Rebecca S. Eisenberg, The Shifting Functional Balance of Patent and Drug Regulation, Health Aff. Sept./Oct. 200I, at 119, 123-29; see also, e.g., In re Warfarin Sodium Antitrust Litig., No. MDL 98-1232-SLR, 1998 U.S. Dist. LEXIS 19555, at*6-*16 (D. Del. Dec. 7, 1998) (involving suit hy generic manufacturer of warfarin sodium against brand name manufacturer of Coumadin on antitrust grounds for, inter alia, attempting to influence the FDA to delay introduction of a generic alternative); Mylan Labs., Inc. v. Akzo, N.V., 770 F. Supp. I053, 1053-54 (D. Md. 1991) (involving suit by brand name manufacturer of prescription drugs against various manufacturers of generic alternatives for antitrust violations alleging inappropriate conduct before the FDA).

216. See, e.g., Cheminor Drugs, LTD. v. Ethyl Corp., 168 F.3d 119, 119, 123-27 (3d Cir. 1999) (involving antitrust suit by bulk producer of ibuprofen against defendant for 
In this respect, recent changes in the Supreme Court's interpretation of the Noerr-Pennington doctrine appear to be having some potentially unforeseen consequences. In highly regulated industries such as health care, government processes can be manipulated to impede competition even if the underlying regulatory claims are not wholly without merit. Nonetheless, in Professional Real Estate Investors, the Court announced new, more restrictive parameters for the "sham" exception to political action immunity from antitrust scrutiny, holding that conduct would not be considered a sham unless it were "objectively baseless." 217 Applying this standard, courts in our sample have immunized a wide range of competitively questionable conduct involving pharmaceutical patents, FDA regulation, and ITC proceedings. ${ }^{218}$ These are settings in

bringing allegedly baseless antidumping claims against it before the ITC); Bio-Tech. Gen. Corp. v. Genentech, Inc., 886 F. Supp. 377, 377 (S.D.N.Y. 1995) (concerning foreign producer of human growth hormone with FDA approval to import into United States who sued defendant for antitrust violations in instigating allegedly baseless patent infringement proceedings before the ITC); Novo Nordisk of N. Am. Inc. v. Genentech, Inc., 885 F. Supp. 522, 522-26 (S.D.N.Y. 1995) (involving antitrust suit by producer of genetically engineered pharmaceutical products against defendant for bringing allegedly baseless patent infringement proceedings before the ITC and for seeking enforcement of patents allegedly procured by fraud before the patent office).

217. Prof'1 Real Estate Investors, Inc. v. Columbia Pictures lndus., 508 U.S. 49, 60-61 (1993) [hereinafter PRE]. The Court said:

We now outline a two-part definition of "sham" litigation. First, the lawsuit must be objectively baseless in the sense that no reasonable litigant could realistically expect success on the merits. If an objective litigant could conclude that the suit is reasonably calculated to elicit a favorable outcome, the suit is immunized under Noerr, and an antitrust claim premised on the sham exception must fail. Only if challenged litigation is objectively meritless may a court examine the litigant's subjective motivation. Under this second part of our definition of sham, the court should focus on whether the baseless lawsuit conceals "an attempt to interfere directly with the business relationships of a competitor," through the "use [of] the governmental process-as opposed to the outcome of that process-as an anticompetitive weapon."

Id. (footnote and citations omitted).

218. For patent disputes, see C.R. Bard, 157 F.3d at 1369 (reversing trial verdict and holding that patent suit was not objectively baseless and therefore could not constitute sham litigation); Mitek, $21 \mathrm{~F}$. Supp. 2d at 1318 (granting plaintiff's motion for summary judgment on defendant's counterclaim and holding that patent infringement suit was not objectively baseless); Boston Scientific Corp., 983 F. Supp. at 272-73 (finding underlying patent litigation suits were immune from antitrust challenge because they were not objectively baseless). For immunized proceedings before the FDA, see In re Warfarin, 1998 U.S. Dist. LEXIS 19555 , at $* 24-27$ (holding defendant's petition to stay plaintiff submitting an abbreviated new drug application ("ANDA") to the FDA until the adoption of stricter bioequivalence standards was immunized under the Noerr-Pennington doctrine because it was not objectively baseless). Cf. Mylan Labs., 770 F. Supp. at 1064 (holding, in a decision antedating $P R E$, that defendant's efforts to gain FDA approval for its generic drugs using an ANDA constituted Noerr-protected conduct). For cases finding immunized conduct before the ITC, see Cheminor Drugs, 168 F.3d at 128 (finding independent objective basis existed for ITC suit and therefore conduct was immunized); Bio-Tech. Gen. Corp., $886 \mathrm{~F}$. Supp. at 382 (holding ITC proceedings were not objectively baseless and were therefore Noerr-protected). 
which rights conferred by law and regulation can determine the identity of market participants and the very scope and nature of the market. When the economic stakes are so high, expansive Noerr immunity invites strategic manipulation by competitors. Moreover, abdication of oversight responsibility by antitrust courts does not imply corresponding acceptance by patent officials, FDA regulators, or the 1TC of a duty to police the potentially anticompetitive conduct of those who appear before them. ${ }^{219}$

Courts are also insufficiently attentive to problems of organizational innovation (as opposed to technological innovation). A recurring problem noted in our sample is that strict limitation of standing to traditional customers and competitors in an industry undergoing organizational transformation will inappropriately favor the status quo. In Barton $\mathcal{E} \mathcal{F}$ Pittinos, Inc. v. SmithKline Beecham Corp., for example, the plaintiff, a pharmaceutical marketing company, was developing a new system for marketing and distributing a hepatitis-B vaccine to nursing homes using a single wholesale pharmacy distributor. ${ }^{220}$ Local pharmacies, who would have been cut out of this line of business, allegedly flooded the vaccine's manufacturer, SmithKline Beecham, with complaints and the new system was quickly terminated.221 The Third Circuit affirmed summary judgment for the defendant on standing grounds, reasoning that the plaintiff was neither a consumer nor a competitor of the defendant. ${ }^{222}$ This was not the only possible outcome. The law of standing could have accommodated concerns about organizational innovation, but those considerations were not appreciated by the court. ${ }^{223}$

219. Ironically, liability for attempting to enforce a fraudulently obtained patent, established in Walker Process Equip., Inc. v. Food Machinery \& Chemical Corp., 382 U.S. 172 (1965), may constitute one of the few sham type theories that survives the sweep of PRE. See, e.g., Nobelpharma AB, 930 F. Supp. at 1253, 1257 (holding that PRE does not extend immunity to defendant who initiated litigation defending a patent obtained through knowing fraud); Novo Nordisk, 885 F. Supp. at 526-27 (dismissing plaintiff's antitrust claim hrought on "objectively baseless" sham litigation theory, but allowing claim alleging fraudulent procurement of a patent on a Walker Process theory). The Court in PRE expressly left open the question of the relationship between its "objectively baseless" standard and the scope of Walker Process liability. See PRE, 508 U.S. at 61-62 n.6. But see Cheminor Drugs, 168 F.3d at 123 (holding that nonmaterial misrepresentations would not deprive an antitrust defendant of Noerr immunity).

220. 118 F.3d 178, 179 (3d Cir. 1997).

221. 1d. at 180 .

222. 1d. at 184 .

223. See Associated Gen. Contractors of Cal., Inc., v. Cal. State Council of Carpenters, 459 U.S. 519, 536-37 (1983) (articulating flexible test analogous to common law definition of probable cause). Similar concerns are raised by Practice Perfect, Inc. v. Hamilton County Pharm. Ass'n, 732 F. Supp. 798 (S.D. Ohio 1989). The plaintiffs were starting a prescription repackaging business in which the plaintiffs would prepare appropriate labels and dosages for drugs and sell them to physicians who would sell the drugs directly to patients. Id. at 799. Defendant pharmacists and pharmacy association allegedly engaged in conduct that deterred wholesale pharmacy distributors from doing business with the plaintiffs, and that also deterred the participation of local physicians. Id. at 800-01. The court dismissed the complaint, reasoning that the plaintiffs' business was too speculative to 
On the other hand, some courts seem capable of addressing innovation concerns within traditional antitrust doctrines. For example, the court in Reazin v. Blue Cross $\mathcal{E}^{\circ}$ Blue Shield of Kansas, Inc. was appropriately alert to the danger that Blue Cross \& Blue Shield's boycott of a new HMO might slow the structural transformation of the health care industry. ${ }^{224}$ Similarly, DM Research, Inc. v. College of American Pathologists involved changes in professional standards (and new technologies) permitting clinical laboratories to produce reagent water on site. ${ }^{225}$ The plaintiff, a seller of reagent water whose business was harmed by on site production, alleged that the defendant's new standards violated antitrust laws. ${ }^{226}$ The First Circuit dismissed the suit, acknowledging the benefits of both technological and organizational innovation. ${ }^{227}$ The opinion in Ortho Diagnostic Systems, Inc. v. Abbott Laboratories, Inc. reflects a similar attention to innovation, this time by factoring the comparative efficiency of market actors into an examination of a plaintiff's predatory pricing claim. ${ }^{228}$ The case involved an antitrust challenge to Abbott Laboratories' use of "bundled pricing" for blood screening tests. ${ }^{229}$ Even though the defendant possessed substantial market power, the court excused its conduct out of respect for maintaining incentives for innovation.

8. Managed Care, Antitrust, and Quality. - As discussed above, the growth of managed care has prompted concern that competitive forces are concentrated on the price front and are incompletely deployed with respect to quality. There is little evidence in our sample of cases directly addressing this concern. Despite the fundamental restructuring of health care markets over the past two decades and the contemporary dominance of managed care in a large number of markets, antitrust litigation directly concerning managed care represents only a small percentage of total medical antitrust cases resulting in opinions. Only $16 \%$ of the disputes we studied involved the insurance sector, and one-fourth of these involved provider sponsored contracting entities such as IPAs.

Why isn't antitrust litigation involving managed care companies and managed care issues more common? Given the relative novelty of managed care, and the time lag between unlawful conduct, the filing of a claim, and the issuance of a judicial opinion, it is possible that a number of cases are still in the pipeline. However, there are other possible reasons why managed care has not yielded as much antitrust litigation as other aspects of the health care sector.

grant them antitrust standing. Id. at 803-04. Unfortunately, strict standing doctrines coupled with insufficient attention to organizational innovation can lead courts to deny relief to parties that may well be market innovators.

224. 899 F.2d 951, 970-71 (10th Cir. 1990).

225. 170 F.3d 53, 54 (1st Cir. 1999).

226. Id. at 55 .

227. Id. at 57 .

228. 920 F. Supp. 455, 469-70 (S.D.N.Y. 1996).

229. Id. at 458. 
First, managed care plans are more likely to prosper in larger metropolitan markets, where it is difficult for a single plan to accumulate market shares that would subject its conduct to heightened antitrust scrutiny. Second, the relationship between managed care plans and health care providers is easier for courts to conceive as being predominately vertical and arm's length in nature. Whereas hospital defendants in staff privileges cases (and some exclusive contracting cases) are often accused of abetting exclusionary conduct by physicians, managed care defendants are powerful economic actors in their own right, and are more likely to be sued as monopolists or oligopolists than as cartel managers. In their dealings with physicians, managed care plans therefore enjoy the favorable antitrust treatment traditionally associated with vertical restraints on trade. Third, managed care plans offer a combination of health care financing (insurance) and medical services. To the extent that courts have focused on the financing aspect of managed care, they have tended to define the relevant product and geographic markets very broadly and to assume relatively low barriers to entry for new market participants. ${ }^{230}$ Fourth, at least in the initial stages of managed care, antitrust courts tended to view insurance company activism as aggressive but nonetheless appropriate purchasing, allowing them to invoke antitrust law's relative leniency toward the buyer's side of the market. ${ }^{231}$ Finally, managed care plans can be structured in ways that can decrease antitrust liability or that reduce the incentives that likely plaintiffs have to sue. Tightly integrated forms of managed care, such as staff model HMOs, can claim the shelter that Copperweld affords against challenges to intraenterprise conspiracies. ${ }^{232}$ The less tightly integrated forms of managed care providers that dominated the industry in the mid and late 1990s are also unlikely to present antitrust issues, but for different reasons. These networks are largely nonexclusive, allowing them to comply with the safety zones contained in the DOJ/FTC Policy Statements. ${ }^{233}$

Regardless of the small number of cases we identified, however, it is indisputable that antitrust law has helped clear the space necessary for the development of managed care. For example, several early cases in our sample involve public plaintiffs, insurance companies, or managed care plans using the antitrust laws to challenge provider resistance, often on quality related grounds, to utilization review and other forms of third

230. See, e.g., Blue Cross \& Blue Shield United of Wis. v. Marshfield Clinic, 65 F.3d 1406, 1411 (7th Cir. 1995) (rejecting notion of a separate HMO market); Ball Mem'l Hosp., Inc. v. Mutual Hosp. Ins., Inc., 784 F.2d 1325, 1334-35 (7th Cir. 1986) (crediting district court finding that there are no barriers to entry in medical insurance field).

231. See, e.g., Kartell v. Blue Shield, Inc., 749 F.2d 922, 927-29 (1st Cir. 1984) (upholding fixed prices for physician services by the state's largest insurer as "rational purchasing").

232. See supra note 92 .

233. See supra notes $155-156$ and accompanying text. 
party oversight of professional practice. ${ }^{234}$ Even later cases, such as Blue Cross $\mathcal{E}$ Blue Shield United of Wisconsin v. Marshfield Clinic, pursue similar themes. ${ }^{235}$ In Marshfield, a potential managed care competitor sued the largest physician group practice in northeastern Wisconsin and its captive HMO, accusing the group practice of various types of exclusionary conduct. ${ }^{236}$

More recently, courts have rejected a number of antitrust claims brought against managed care plans that would have impaired the ability of those plans to achieve their cost containment and management objectives. Many of these cases represent creative efforts on the part of physicians to attack other contemporary insurance practices by reinventing a number of the arguments previously employed to justify professional resistance to utilization review. Within our sample, the most common plaintiff/defendant pairing relating to managed care consisted of physicians suing insurers or HMOs (20 disputes), usually over access to "preferred provider" networks or restrictive provisions in provider contracts. ${ }^{237}$

234. See, e.g., FTC v. Ind. Fed'n of Dentists, 476 U.S. 447, 455, 465-66 (1986) (finding concerted refusal by defendant dentists to deny third party payors the x-rays they needed to engage in utilization review to be an antitrust violation); Reazin v. Blue Cross \& Blue Shield of Kan., Inc., 635 F. Supp. 1287, 1333 (D. Kan. I986) (finding genuine issue of material fact on antitrust claim that defendant terminated hospital that contracted with plaintiff HMO in order to deter other hospitals from dealing with plaintiff). These challenges were not always successfuI, reflecting the persistence of judicial deference to professional judgment. See Pa. DentaI Ass'n v. Med. Serv. Ass'n of Pa., 632 F. Supp. 653, 661, 676, 679 (M.D. Pa. 1986), rev'd, 815 F.2d 270 (3d Cir. 1987). Pennsylvania had sued the state's dental society and subsequently settled its claims. 1d. at 656 . Blue Cross \& Blue Shield, who had been impleaded as a third party defendant, filed a third party counterclaim against the defendant dentists for illegal boycott of the its dental plan and for interference with its cost containment initiatives. Id. at 656-57. The district court granted the dentists' motion for summary judgment, accepting their argument that the need to ensure quality of care through professional self regulation justified their opposition to the insurer's utilization review measures. 1d. at 679. The circuit court, however, found this rationale unconvincing on appeal. Pa. Dental Ass'n, 815 F.2d at 277 ("[PIaintiffs] contend that they have associational interests in advancing the standards of professional care which motivated their actions in this case. Those interests are not so great, however, as to afford a shield to professional conduct which forecloses competition.").

235. 65 F.3d at 1408. In Marshfield, however, the defendant medical clinic prevailed. 236. Id.

237. See, e.g., Doctor's Hosp. of Jefferson, Inc. v. Southeast Med. Alliance, Inc., 123 F.3d 301, 304 (5th Cir. 1997) (concerning hospital terminated from preferred provider organization (PPO) which alleged anticompetitive effects based on the fact that PPO subscribers would be denied the choice of using its services); Levine v. Cent. Fla. Med. Affiliates, Inc., 72 F.3d 1538, 1541 (11th Cir. 1996) (involving suit by physician against hospital over revocation of staff privileges and against PPO over denial of his application to join its network); Cont'l Orthopedic Appliances, Inc. v. Health 1ns. Plan of Greater N.Y., 956 F. Supp. 367, 369 (E.D.N.Y. 1997) (involving suit by supplier of orthotic and prosthetic equipment against HMO that entered into an exclusive contract with its rival); Fogel v. Metro. Life Ins. Co., 871 F. Supp. 571, 573 (E.D.N.Y. 1994) (concerning suit by supplier of medical devices against insurance company when the defendant failed to include plaintiff 
Managed care cases have also helped refine antitrust analysis of consumer choice in health care. Even though courts in other contexts appropriately view restrictions on choice as potentially anticompetitive, judicial opinions in our sample usually have appreciated the fact that some level of exclusivity in provider networks is an essential component of managed care, ${ }^{238}$ and have allowed consumers to select price-quality combinations that would not otherwise be available in the marketplace. ${ }^{239}$ It is also worth noting that many of the hospital exclusive contracting cases in our sample resulted, at least indirectly, from the cost pressures on hospitals prompted by managed care. As described above, these cases have produced the clearest judicial understanding of the relationships among price, choice, and quality of care. ${ }^{240}$

In Ambroze v. Aetna Health Plans, for example, several anesthesiologists sued a group of managed care plans alleging that they were conspiring with local hospitals to coerce physicians to sign provider contracts

in a list of preferred suppliers); Capital Imaging Assocs. v. Mohawk Valley Med. Assocs., 725 F. Supp. 669, 672-73, 675 (N.D.N.Y. 1989) (involving radiology practice which argued that lack of access to defendant health plan would deprive it of the resources necessary to support and maintain its sophisticated diagnostic equipment, and that its exclusion deprived physicians of the opportunity to select a radiologist based on quality); Hassan v. Indep. Practice Assocs., 698 F. Supp. 679, 681 (E.D. Mich. I988) (concerning suit by allergy specialist against HMO that refused to readmit him following his resignation, which had resulted from his complaints about utilization review and cost containment).

238. See Levine, 72 F.3d at 1553 (finding that many dimensions of choice remain in managed care, such as choice of plan at enrollment and ability to switch plans if dissatisfied); Marshfield, 65 F.3d at 1409 (noting that the essential nature of any HMO is to limit consumer choice to in-network options); Doctor's Hosp. of Jefferson v. Southeast Med. Alliance, 897 F. Supp. 290, 294 (E.D. La. 1995) (rejecting plaintiff's theory that consumers are denied choice as a result of PPO's exclusion of one hospital); Hassan, $698 \mathrm{~F}$. Supp. at 696 (asserting that failure to include plaintiffs in HMO network does not limit consumer choice because plaintiffs are still in the market and HMO members have range of other allergists to choose from); Reazin, 635 F. Supp. at 1299 (indicating managed care options necessarily restrict patient's choice of provider).

239. E.g., Smilecare Dental Group v. Delta Dental Plan of Cal., 858 F. Supp. 1035, 1038 (C.D. Cal. 1994), aff d, 88 F.3d 780 (9th Cir. 1996). Plaintiff Smilecare, a company offering supplemental dental insurance, sued Delta Dental, a large dental insurer, on various antitrust grounds. Id. at 1036-37. The district court dismissed the complaint, concluding that it was important that Delta Dental be allowed to make providers honor its mandatory copayment provisions, which permits the marketing of a wider range of insurance products and ultimately ensures a wider range of consumer choice. Id. at 1038; see also U.S. Healthcare, Inc. v. Healthsource, lnc., 986 F.2d 589, 591 (1st Cir. 1993) (affirming grant of summary judgment to HMO sued by competitor over its exclusive contracts with primary care physicians); Barry v. Blue Cross of Cal., 805 F.2d 866, 867, 872 (9th Cir. 1986) (affirming summary judgment in favor of insurer sued by physician alleging that its PPO plan constituted a price fixing agreement and boycott, and reasoning that lower premiums, utilization review, and quality assurance associated with a PPO offered consumers a new market option).

240. See supra notes I74-175 and accompanying text. 
that compromised the physicians' professional judgment. ${ }^{241}$ Plaintiffs argued that the defendants' strong arm tactics undermined physicians' ability to provide high quality care consistent with professional standards. ${ }^{242}$ Citing language from the First Circuit's opinion in Kartell, the court rejected the plaintiffs' claims, arguing that the plaintiffs were second guessing the working of the market and were trying to impose arbitrary constraints on market outcomes. The court expressed its confidence in the market's ability to function well and provide consumers the combination of price and nonprice attributes that they desire. ${ }^{243}$

There are reasons to suspect that antitrust past will not be antitrust prologue with respect to managed care, and that the number of litigated cases will increase. Most importantly, the managed care industry has undergone waves of consolidation and is reaching levels of horizontal concentration that will subject a wider range of its practices to more intense antitrust scrutiny. If economic conditions continue to worsen, managed care may once again adopt exclusive provider networks, prompting heightened antitrust scrutiny even at relatively low levels of economic concentration. Moreover, as managed care expands into smaller communities, the more concentrated nature of these markets may expose insurers and their contracting partners to greater antitrust liability.

The growing unpopularity of managed care is also likely to influence antitrust litigation. Among other things, public backlash is almost certain to disabuse courts of the notion that insurers are acting solely as consumer surrogates. In fact, one case in our sample suggests that courts may be willing to hear complaints directly from patients about provider network exclusions that they would probably not entertain if made by the providers themselves. In Rozema $v$. Marshfield Clinic, a Medicaid recipient sued a physician multispecialty clinic and its affiliated health plans, alleging an illegal conspiracy to divide markets. ${ }^{244}$ Specifically, the plaintiff challenged defendants' policy of forcing all chiropractors who wanted to provide covered services to join a single practice group. Plaintiff's chiropractors (who allegedly had relieved her lower back and leg pain with a special technique) did not merge into the practice, and defendants refused to provide continued coverage. ${ }^{245}$ Even on these unremarkable facts, the district court denied the defendants' motion to dismiss the claim. ${ }^{246}$

241. No. 95 CIV. 6631 (DLC), 1996 U.S. Dist. LEX1S 7274, at*12-*14 (S.D.N.Y. May 28, 1996), vacated, remanded, No. 96-7778, 1997 U.S. App. LEXIS 1048 (2d Cir. Jan 24, 1997).

242. Id. at *14.

243. Id. at $* 30-31$.

244. No. 96-Cr592-C, 1997 U.S. Dist. LEX1S 8261, at *1 (W.D. Wis. Mar 10, 1997).

245. Id. at *11-*12.

246. Id. at *47. Subsequently, the district court granted the plaintiffs' motion for class certification on their amended complaint, Rozema v. Marshfield Clinic, 176 F.R.D. 295, 297 (W.D. Wis. 1997), and denied the defendants' motion for summary judgment in all respects, except for the dismissal of one of the defendants due to insufficient evidence 
On the whole, however, there is little evidence in our data either that courts have developed usable models of quality competition in non-managed care cases that can be applied to managed care, or that courts in recent cases involving managed care are productively climbing a learning curve with respect to quality. Some progress has been made in evaluating the competitive significance of restricting consumer choice within managed care plans, which is important to the process of "selective contracting" between insurers and physicians or hospitals. And courts remain skeptical about health care providers' efforts to secure legal exemptions from managed care for the sake of quality, although it remains to be seen whether popular distrust of managed care will cause judges to reevaluate their biases. Still, antitrust law is not yet being used affirmatively to defend quality competition in managed care, even though business conduct that raises quality concerns is increasingly common.

\section{Conclusion}

This Article has reported the results of a comprehensive empirical review of judicial opinions in medical antitrust litigation between 1985 and 1999, with specific attention to courts' handling of quality and other nonprice issues. In brief, we found that the bulk of medical antitrust litigation involves private plaintiffs rather than public enforcement agencies, that most claims relate to longstanding issues of physician-hospital relations rather than novel commercial practices involving technology or managed care, and that few cases generate outcomes favorable to plaintiffs. Our data confirm previous studies of antitrust claims and extend those findings to the health care arena, which has not been investigated empirically through the lens of antitrust law. With respect to quality, the results of our investigation lead us to conclude that no cogent theory of nonprice competition has been developed to guide courts in specific cases, that historical factors and legislative interventions often cause courts to divorce quality from competition rather than factoring it into a competitive mix, that judicial decisions granting the health care industry special prerogatives to preserve quality despite anticompetitive effectsaberrant in economic if not health services theory-are localized to a small number of hospital merger cases, and that courts have made some progress analyzing consumer choice and information as procompetitive nonprice characteristics. These issues have not been explored previously in empirical research.

In this concluding Section, we shift away from the social science mode of reporting and discussing empirical findings characteristic of the rest of the Article, and offer our impressions of what our results suggest with respect to the conceptual nexus between antitrust law and health

linking it to the alleged conspiracy. Rozema v. Marshfield, 977 F. Supp. 1362, 1365 (W.D. Wis. 1997). 
policy, Our study focuses on the American health care system, which has recently undergone a wrenching transformation from a professionally dominated to a market driven paradigm. In particular, the rise of managed care and the accelerating pace of technological progress in medicine make it necessary to determine whether, as a matter of public policy, an acceptable combination of price and quality characteristics will emerge from competition involving health care products, medical services, and insurance. We believe that our study sheds some light on this question.

Our study confirms that antitrust law cannot be expected to serve as the sole oversight mechanism for industries as complex and quality dependent as health care. Part of the problem, at least from the standpoint of private litigation, is structural. The existing constellation of factors (damage provisions, fee shifting rules, and standing and injury requirements) that determine which private cases will be pursued, which issues will be litigated, and how those issues will be framed for resolution are not fully meeting social needs. Another part of the problem is intellectual. Courts possess a limited grasp of what constitutes health care quality and how competition can be designed to further it. In time, antitrust courts and lawyers may be the residual beneficiaries of increasingly sophisticated understandings of nonprice competition in economic theory and more refined models of quality from the health services research literature, but theory will continue to confront serious institutional constraints in litigation. Unless theoretical and empirical advances can be translated into fairly simple decisionmaking heuristics, they will be of little practical use to the courts. A final part of the problem is ideological. Thinking about health care quality as a component of competition rather than a professional or regulatory matter requires a conceptual shift. Our data suggest that some courts have started to make this transition, particularly in the area of exclusive contracting.

We also believe that our research offers valuable, generalizable lessons for many regulated or previously regulated industries regarding the border between competition, which is monitored and safeguarded primarily by antitrust law, and regulation, which modifies competitive conditions to serve other socially desirable ends. The most important lesson is that competition can and should meet regulation at an interface, not a boundary. For several decades, health economists have argued about the "marketability" of medical care, the extent to which competition can function effectively given the many imperfections of medical markets. In his seminal I963 article, for example, Kenneth Arrow posited that information asymmetries render health care largely nonmarketable, and that other social and legal institutions are needed to fill the "optimality gaps" created by nonmarketability. ${ }^{247}$ Although the marketability of health care has been vigorously contested since Arrow's exposition, analyses of 
this type have been used by scholars and policymakers of all ideological persuasions to justify a sharp demarcation between the province of competition and that of government regulation (or professional selfregulation).

We disagree. Even in Arrow's time, it was difficult to discern whether regulatory and self-regulatory processes were supplanting competition or assisting it. For example, the beneficial effect exerted by professional ethical codes on physician-patient trust can be viewed either as an externally derived substitute for markets rendered nonfunctional by lack of information, or as an internal adaptation by economically self-interested physicians to convey reputational information credibly and allow patients to make market choices. Our empirical data evidence similar ambiguities across fifteen years, many forms of market structure, and a variety of commercial behaviors. 1t is clear from our study that, as we expected, quality sits at the interface between competition and regulation, incapable of being fully incorporated into competitive analysis but impossible to partition from the more familiar forms of competition over price and output. Courts are often inconsistent in how they assign particular situations that present quality concerns to market or nonmarket (regulatory) categories, but overall they show a fair amount of resilience in their attempts to blend competitive and regulatory perspectives and determine the effect of challenged conduct on nonprice as well as price competition.

How can one create a robust interface? Another lesson that emerges from our data is that one must pay attention both to substantive law and to legal institutions. With respect to the former, there is a tendency among health policy experts to compile lists of "market failures" in the health care system, and then look to law to remedy or circumvent them. We see in our data a more fluid if theoretically unformed process that brings the existence of market failure into the competitive analysis of conduct challenged under antitrust law, an approach arguably made explicit in the Supreme Court's opinion in California Dental Ass'n. Information failures and agency failures (perhaps including moral hazard in insurance relationships) seem best suited to be treated in this fashion. Our data suggest that the DOJ and FTC are taking the lead in formulating enforcement policies that preserve consumer choice, promote market entry, facilitate the free flow of information, and foster technological and organizational innovation. This finding is most apparent in the decisionmaking heuristics that emerge from our examination of enforcement agency consent decrees. While a number of these factors register in judicial opinions as well, courts seem implicitly to assume, probably incorrectly, that price-quality decisions made by insurance companies, hospitals, and physicians coincide with consumer preferences. While managed care is certainly market driven, it is not necessarily any more patient driven than the traditional professional paradigm it displaced. On the other hand, courts appear to be successfully managing the competitionregulation interface in terms of consumer choice aspects of quality, de- 
spite the fact that choice has historically been regulated as intensively as any other quality parameter in health care. A possible explanation is that courts have greater confidence in their nonexpert perceptions of choice than in aspects of quality that require greater technical medical knowledge.

On the other hand, certain market failures may be incompatible with competitive analysis, and therefore may require separate treatment under substantive law. The clearest examples in our case sample involve distributional considerations such as access and availability (perhaps also including adverse selection in insurance relationships, and likely including public goods) and situations involving personal integrity and motivation. The nonprofit hospital merger cases demonstrate these problems. In several of these cases, courts felt obligated to ensure that competition benefited patients who were not consumers (the underinsured and the uninsured) as well as those who were, and consequently strayed from a sound competitive analysis-which has no place for cross-subsidies-in order to promote post merger charity care. Similarly, courts evaluating conduct by nonprofit organizations, whose trustees were pillars of their communities, often found it impossible to limit their analysis to objective effects and ascribed undue importance to the motives of the participants (far beyond the extent to which motive might shed light on likely competitive consequences).

Turning to the question of legal institutions, our empirical method of combining aggregate information about antitrust litigation with nuanced readings of individual judicial opinions is an apt metaphor for the problem we are addressing. Antitrust is one of those areas in which courts must address problems whose scope extends to communities if not whole societies through the adjudication of private, partisan disputes. Significantly, it is our impression in reviewing the cases in conjunction with the results of the survey instrument that courts deciding medical antitrust issues managed to get the big picture right. By applying traditional antitrust principles to health care markets, courts helped break down professional resistance to price competition. After managed care took hold, courts by and large were not deceived by self-interested efforts to use the antitrust laws to undermine its growth. Moreover, some courts have begun to sense and address the competitive risks of integration and consolidation within managed care.

Some of tbis success may be attributable to the overlapping forms of accountability among the institutions that determine antitrust law. At their best, antitrust courts combine categorical and contextual approaches to the cases before them, applying economic principles, factoring in legislative rules and exceptions, paying attention to agency expressions of administrative priorities, but ultimately dealing with issues at the competition-regulation interface such as quality using the instincts and sensitivities of their equitable authority. The ability of federal courts to manage complex issues under the organic, common-law-type mandate of 
the antitrust laws is quite substantial, even if our study reveals that such promise has only been partially realized.

What does the future hold? Whether in health care or other sectors of the economy, courts will not be able to avoid increasingly complicated questions of quality and nonprice competition. In health care alone, courts will have to deal with the intersection of patent and antitrust law in the area of generic drugs, issues of prescription drug pricing and distribution, and the effects of managed care in increasingly concentrated markets. Outside of health care, courts will be faced with evolving and complex markets in information technology, intellectual property, energy, and telecommunications. Our study suggests that antitrust courts cannot handle these tasks by themselves. This fact highlights the importance of developing a broader "competition policy" for health care and other transitional industries in which antitrust law would work in concert with regulatory, private purchasing, and self-regulatory initiatives to assure that both price competition and nonprice competition are vigorous, and that social objectives not reducible to competition are addressed. 


\section{APPENDIX}

\section{Robert Wood Johnson Foundation Project}

Competing On Quality Of Care:

Comparing Antitrust LaW To Market Reality

Review Of Judicial Decisions Involving Health Care Antitrust

CAse Coding Form

May 31, 2000

\section{General Instructions:}

- Codes should be hand-written in red or blue ink in the margin of each printed case, adjacent to where information appears.

- Codes should be written in the form Numeral-Numeral-Numeral. For example, a case brought by the FTC as plaintiff should be marked 1-1-2.

- After you have completed coding each case, the coding information should be copied onto a properly labeled cover sheet, which should be stapled to the first page of the case.

- When requested in the coding form, relevant text should be highlighted in yellow. Please limit actual highlighting to specifically requested items.

- If you find language in the opinion that deals with quality issues but does not exactly match a requested code, or any other information that you would like to draw the Project Directors' attention to, feel free to underline it in pen or make a pen mark in the margin. You should also feel free to write comments in the indicated section of the cover sheet.

\section{"SECTION 0": GENERAL ITEMS}

0. General Items (write at top of case rather than in margin)

1. Coder (full name)

2. Date of coding $(\mathrm{mm} / \mathrm{dd} / \mathrm{yy})$

3. Is the opinion about antitrust law?

1. "Mostly antitrust"

2. "Some antitrust"

3. "Antitrust mentioned, but specific antitrust question not before the court"

4. "Essentially no antitrust"

4. Is the opinion about health care?

1. "Mostly health care"

2. "Some health care"

3. "Essentially no health care"

4. "Health care discussed, but only as an analogy or comparison" 
Helpful hints:

- Items 0-3 and 0-4 can only be completed after you have read the opinion.

- Items 0-3 and 0-4 require judgment on your part. You should answer them based on the specific opinion you are coding, not the larger dispute of which it is a part. For example, a complicated dispute may give rise to many opinions, most dealing with discovery motions. If a particular opinion discusses only rules of civil procedure or some other tangential matter, it should be coded 0-3-4 and 0-4-3, even if the overall dispute is about both health care and antitrust law.

- If you code a case 0-3-3, indicating that the case is primarily about an area of law other than antitrust (e.g., patent law, FDA regulation), feel free to add a comment to that effect on the cover sheet.

\section{"SECTION 1": PLAINTIFF}

\section{Plaintiff}

1. Type of plaintiff (note all that apply)

1. Department of Justice (United States)

2. Federal Trade Commission

3. State Attorney General

4. Private Plaintiff

5. Other (specify)

2. If private, plaintiff's business (note all that apply; if possible, indicate principal plaintiff as (PP) in margin and circle entry on cover sheet)

1. Hospital, academic medical center or hospital system/chain

2. Skilled nursing facility

3. Other health care facility (specify)

4. Physician solo or small-group practice ( $<25$ physicians)

5. Physician large group practice (25 or more physicians)

6. HMO

7. Insurance company (including Blue Cross/Blue Shield)

8. Contracting intermediary (e.g., PPO, IPA, PPMC, MSO, PHO)

9. Pharmaceutical/medical device/biotechnology company (inc. pharmacy, PBM)

10. Other medical supplier (e.g., ambulance, DME) (specify)

11. Professional/trade association

12. Non-physician health professionals (nurses, chiropractors, dentists, etc.)

13. Hospital medical staff (as an entity)

14. Hospital-based department (e.g., radiology, pathology, anesthesia, ER)

15. Other (specify)

3. If private, plaintiff's governance structure (note all that apply) 
1. For-profit (inc. individuals, partnerships and mutual insurers)

2. Nonprofit corporation

3. Not determinable (e.g., hospital status not identified)

\section{"SECTION 2": DEFENDANT}

\section{Defendant}

1. Defendant's business (note all that apply; if possible, indicate principal defendant as (PD) in margin and circle entry on cover sheet)

1. Hospital, academic medical center or hospital system/chain

2. Skilled nursing facility

3. Other health care facility (specify)

4. Physician solo or small-group practice ( $<25$ physicians)

5. Physician large group practice (25 or more physicians)

6. HMO

7. Insurance company (including Blue Cross/Blue Shield)

8. Contracting intermediary (e.g., PPO, IPA, PPMC, MSO, PHO)

9. Pharmaceutical/medical device/biotechnology company (inc. pharmacy, PBM)

10. Other medical supplier (e.g., ambulance, DME) (specify)

11. Professional/trade association

12. Non-physician health professionals (nurses, chiropractors, dentists, etc.)

13. Hospital medical staff (as an entity)

14. Hospital-based department (e.g., radiology, pathology, anesthesia, ER)

15. Regulatory agency or other government entity

16. Other (specify)

2. Defendant's governance structure (note all that apply)

1. For-profit (inc. individuals, partnerships and mutual insurers)

2. Private nonprofit corporation

3. Public (inc. public hospital, government agency)

4. Not determinable (e.g., hospital status not determinable)

5. Geographic location of defendant's business

6. Large city

7. Suburban area

8. Small city/town

9. Rural area

10. Statewide/Regional

11. National/global

12. Not determinable (specify place name and state) 


\section{"SECTION 3": BUSINESS AND LEGAL CONTEXT}

\section{Business and Legal Context}

1. Type of behavior involved (note all that apply)

1. Corporate merger or acquisition

2. Corporate joint venture

3. Medical staff privileges, including denial or termination (hospitals only)

4. Exclusive/selective contracting, including refusals to refer patients (hospital, other health facility, medical group, pharmacy, supplier, or other corporate entity)

5. Network participation, including termination (individual health professionals)

6. Joint contract negotiation (inc. conduct of providers dealing with payors)

7. Unilateral imposition of contract terms (e.g., most favored customer clause)

8. Payor standards and practices (conduct of payor)

9. Private credentialing, standard-setting, or accreditation (inc. by professional associations)

10. Professional organization rules/membership

11. Joint purchasing

12. Sharing of information

13. Advertising and marketing (including prohibitions on such)

14. Other (specify)

2. Procedural status (note all that apply)

1. Motion for injunction

2. Motion for summary judgment or motion to dismiss

3. Post-trial motion

4. Appeal by plaintiff

5. Appeal by defendant

6. Other (inc. minor motions) (specify)

3. Disposition of case (note all that apply)

1. Significant judgment/verdict for plaintiff

2. Significant judgment/verdict for defendant

3. Remand (unless purely ministerial)

4. Other (inc. minor motions) (specify)

4. Remedies ordered by the court (note all that apply)

1. Injunction (specify)

2. Cease and desist order

3. Divestiture

4. Compulsory licensing

5. Damages

6. Criminal penalties

7. Other (specify) 
Helpful hints:

- Coding of procedural status (Item 3-2) and disposition (Item 3-3) requires judgment on your part.

- Interim motions (e.g., discovery, exclusion of evidence) should be coded procedurally as 3-2-6 and briefly specified, as should opinions dealing with minor counterclaims or cross-appeals.

- Disposition codes 3-3-1 and 3-3-2 should be reserved for significant outcomes of litigation, such as complete or near-complete dismissals or grants of summary judgment (even if reversed on appeal in another opinion), affirmances on appeal, and reversals on appeal where remand, if any, is purely ministerial and will not affect the ultimate outcome. Rulings on minor motions, minor claims/counterclaims, minor appeals/cross-appeals, and other interim matters should be coded 3-3-4 and briefly specified.

- Disposition code 3-3-3 should be used where the court to which the case is remanded must engage in significant activity whose outcome remains uncertain. Rulings on interim matters such as motions.

\section{"SECTION 4": ANTITRUST ANALYSIS}

\section{Antitrust Analysis}

1. Allegations addressed substantively by court (mark all that apply)

1. Price fixing (Sherman $\$ 1$ )

2. Geographic market allocation (Sherman § 1)

3. Product market allocation (Sherman $\S 1$ )

4. Concerted refusal to deal (boycott) (Sherman $\S 1$ )

5. Tying (Sherman $\S 1$, Clayton $\S 3$ )

6 . Vertical price restraints (e.g. resale price maintenance) (Sher$\operatorname{man} \S 1$ )

7. Vertical nonprice restraints (e.g. exclusive dealing) (Sherman, Clayton § 3)

8. Other unreasonable restraint of trade (Sherman $\S 1$ )

9. Monopolization (willful acquisition or maintenance of market power) (Sherman $\S 2$ )

10. Attempted monopolization (Sherman $\$ 2$ )

11. Anticompetitive merger or acquisition (Clayton $\S 7$ )

12. Price discrimination (Sherman $\S 2$, Robinson-Patman)

13. Unfair trade practices (FTC Act $\$ 5$ )

14. State law antitrust claims

15. Other (specify)

2. Violations found by court (mark all that apply)

1. Price fixing (Sherman $\S 1$ )

2. Geographic market allocation (Sherman $\S 1$ )

3. Product market allocation (Sherman $\S 1$ )

4. Concerted refusal to deal (boycott) (Sherman $\S 1$ )

5. Tying (Sherman $\S 1$, Clayton $\S 3$ ) 
6. Vertical price restraints (e.g. resale price maintenance) (Sher$\operatorname{man} \S 1$ )

7. Vertical nonprice restraints (e.g. exclusive dealing) (Sherman, Clayton $\$ 3$ )

8. Other unreasonable restraint of trade (Sherman $\$ 1$ )

9. Monopolization (willful acquisition or maintenance of market power) (Sherman $\S 2$ )

10. Attempted monopolization (Sherman $\S 2$ )

11. Anticompetitive merger or acquisition (Clayton $\S 7$ )

12. Price discrimination (Sherman $\S 2$, Robinson-Patman)

13. Unfair trade practices (FTC Act $§ 5$ )

14. State law antitrust claims

15. Other (specify)

Helpful hint: "Addressed substantively" means that the opinion considers the allegations in greater detail than just listing them when reciting the history of the dispute.

3. Analysis of plaintiff's case actually performed by court (note each as it arises; do not highlight text)

1. Per se analysis

2. Quick-look rule of reason

3. Traditional rule of reason (inc. Chicago Board of Trade test)

4. Market definition process

5. Market concentration analysis (HHI, Elzinga-Hogarty) or other test of market power

6. Oligopoly/cartel agreement

7. Other conspiracy or collusion on price or nonprice characteristics

8. Exclusionary conduct (e.g., boycott)

9. Barriers to entry

10. Monopsony power (buyer monopoly)

11. Essential facility doctrine (Terminal Railroad)

12. Conduct of monopolist or attempted monopolist

13. Other (specify)

4. Analysis of defenses actually performed by court (note each as it arises; do not highlight text)

1. No antitrust injury/standing

2. Intra-enterprise "conspiracy" only (Copperweld)

3. Efficiencies under rule of reason (lower costs, economies of scope and scale)

4. Other procompetitive effects under rule of reason (e.g., improved quality)

5. Legitimate business justification (Aspen Ski)

6. Action was as buyer, not seller

7. Natural monopoly

8. State action immunity defense (Parker)

9. Political action defense (Noerr-Pennington) 
10. Health Care Quality Improvement Act

11. McCarran-Ferguson Act (immunity for the business of insurance)

12. Failing firm defense

13. Labor (collective bargaining) exemption

14. Other defense (e.g., renounced conspiracy) (specify)

\section{"SECTION 5": DISCUSSION OF COMPETITION IN HEALTH CARE}

IMPORTANT: For this Section only, add the following supplemental codes if applicable:

CON: Concurring opinion

DIS: Dissenting opinion

If a code is not marked "con" or "dis," we will assume that it is contained in the opinion of the court or majority opinion.

5. Judicial Discussion of Health Care Competition and Price, Output or Quality

1. General beliefs about competition in health care (note each as it arises; do not highlight text)

1. Competition decreases health care prices

2. Competition increases health care prices

3. Competition decreases total health care costs

4. Competition increases total health care costs ("medical arms race," wasteful duplication)

5. Competition increases health care quality

6. Competition decreases health care quality

7. Courts should be cautious applying antitrust rules to health care because of medical professional values

8. Courts should be cautious applying antitrust rules to health care because of social imperatives

9. Courts should strictly apply antitrust rules to health care unless Congress directs otherwise (legislatures, not courts, should create exemptions)

\section{Helpful hints:}

- This section is the most important to the success of the project. When in doubt, please be overinclusive. We can delete unwarranted codes later if needed, but we cannot find material that was incorrectly omitted.

- That said, particularly with respect to discussions of quality (the critical item in the study), you should code and/or highlight material only if it is connected to a discussion of competition. For example, an opinion dealing with hospital staff privileges and peer review activities may discuss quality at length, but only in connection with peer review immunities rather than competitive considerations. In that case, you should not code the discussion, but you should feel free to make pen marks in 
the margin and comments on the cover sheet to indicate interesting text.

- Item 5-1 requires judgment on your part. Unlike most other items, courts' general beliefs about competition will not always be stated explicitly.

- For all the items in this section, "variety" and "choice" are important attributes of quality, even though discussions of them will not always use the word "quality" in connection with them. Please include these discussion in your coding/highlighting.

2. Price and output effects discussed by the court (note each as it arises, do not highlight text)

1. Challenged conduct will increase prices (insurance premiums, co-payments, fees paid to health care providers/suppliers, etc.)

2. Challenged conduct will decrease prices

3. Challenged conduct will decrease output (quantity)

4. Challenged conduct will increase output (quantity)

5. Challenged conduct will allow price discrimination (unjustified differences in prices among buyers)

6. Discussion of relationship between price and output (quantity)

7. Discussion of relationship between price and quality

8. Other price or output concerns (specify)

3. Discussion of firm-specific quality characteristics relating to clinical structure (note each as it arises and HIGHLIGHT RELEVANT TEXT)

1. Advanced technology (adoption, dissemination or availability)

2. Qualifications of physicians or other licensed health professionals (education, board certification, specialization)

3. Adequacy of staffing (e.g., nursing care)

4. Adequacy of physical facilities (other than amenities)

5. Continuity of care (preservation of "provider-patient relationship")

6. Accreditation by private entity (JCAHO, NCQA)

7. Certification/approval by government (FDA, state health department)

4. Discussion of firm-specific quality characteristics relating to clinical processes (note each as it arises and HIGHLIGHT RELEVANT TEXT)

1. Malpractice or negligence of providers (adverse events)

2. Ranking in quality surveys (state report cards, consumer reports)

3. Quantitative success scores (HEDIS, cure rates, mortality, other outcomes)

4. Preventive services (immunization, screening)

5. Product defects

6. Potential for clinical innovation (pharmaceuticals, clinical procedures, practice protocols/guidelines, etc.) 
7. Unspecified quality of patient care concerns

5. Discussion of firm-specific quality characteristics relating to administration (note each as it arises and HIGHLIGHT RELEVANT TEXT)

1. Solvency

2. Nonprofit governance

3. Provision of charity care (uncompensated care)

4. Administrative restrictions (bureaucracy)

5. Health education

6. Consumer information, including advertising (search costs)

7. Amenities

8. Grievance and complaint processes

9. Legal rights and remedies for injury

6. Discussion of firm-specific characteristics relating to overall quality (note each as it arises and HIGHLIGHT RELEVANT TEXT)

1. General reputation for quality or service

2. Duration of existence/stability ("business history"/"community presence")

3. Other (specify)

7. Discussion of market-wide or system-wide quality characteristics (note each as it arises and HIGHLIGHT RELEVANT TEXT)

1. Range of products/services available (product differentiation)

2. Location or geographic reach

3. Freedom of choice among health care providers (physicians, chiropractors, hospitals, etc.)

4. Aids to consumers in making informed choices (including advertising, other information that lowers search costs, access to agents and intermediaries)

5. Technologic or organizational innovation (incl. research and development)

6. Professionalism (ethics)

7. Overall qualifications of physicians or other licensed health professionals

8. Overall quality of hospitals or other health facilities

9. Unspecified quality concerns or quality mentioned in passing only

10. Other (specify)

\section{END OF CODING INSTRUMENT}

